\title{
AVALIAÇÃO RADIOGRÁFICA DE ENXERTO ÓSSEO XENOGÊNICO EM ALVÉOLOS DE TERCEIROS MOLARES INFERIORES NÃO- IRROMPIDOS
}

Dissertação apresentada à Faculdade de Odontologia de Bauru, da Universidade de São Paulo, como parte dos requisitos para obtenção do título de Mestre em Odontologia - área Estomatologia

(Edição Revisada) 


\title{
AVALIAÇÃO RADIOGRÁFICA DE ENXERTO ÓSSEO XENOGÊNICO EM ALVÉOLOS DE TERCEIROS MOLARES INFERIORES NÃO- IRROMPIDOS
}

\author{
ETIENE DE ANDRADE MUNHOZ
}

Dissertação apresentada à Faculdade de Odontologia de Bauru, da Universidade de São Paulo, como parte dos requisitos para obtenção do título de Mestre em Estomatologia

(Edição Revisada)

Orientador: Prof. Dr. Osny Ferreira Junior 
Munhoz, Etiene de Andrade

M 925a Avaliação radiográfica de enxerto ósseo xenogênico em alvéolos de terceiros molares inferiores não-irrompidos / Etiene de Andrade Munhoz. - Bauru, 2005.

121 p.: il.; $30 \mathrm{~cm}$

Dissertação. (Mestrado) - Faculdade de Odontologia de Bauru, Universidade de São Paulo

Orientador: Prof. Dr. Osny Ferreira Junior

Autorizo, exclusivamente para fins acadêmicos e científicos, a reprodução total ou parcial desta dissertação, por processos fotocopiadores e outros meios eletrônicos.

Assinatura : 


\section{ETIENE DE ANDRADE MUNHOZ}

15 de setembro de 1980

Bauru - SP

Filiação

$1999-2002$

$2003-2005$

Associações
Nascimento

Ademir da Jesus Cáceres Munhoz

Marisa Alonso de Andrade Munhoz

Curso de Odontologia Faculdade de Odontologia de Bauru, da Universidade de São Paulo.

Curso de Pós-graduação em Estomatologia, ao nível de Mestrado, na Faculdade de Odontologia de Bauru, da Universidade de São Paulo.

APCD - Associação Paulista de Cirurgiões-Dentistas SBPqO - Sociedade Brasileira de Pesquisa Odontológica 


\section{Agradecimentos}


À Deus,

Sempre presente em minha vida, ifuminando meus caminhos.

Agradeço por todas as minhas realizações e confio $\mathcal{N}$ ele para tudo aquilo que ainda hei de realizar.

Sem Ele nada é possivel.

"Buscai primeiro o Reino de Deus

e a sua justiça.

E tudo mais vos será acrescentado"

$(\mathcal{M} t$ 6, 33) 
À minha família, base de tudo.

Meus queridos pais,

Ademir e Marisa,

meu irmão Bruno

e meus avós,

Israele Maria,

Eduardo (in memorian) e Clemência

Por todo amor, carinho, apoio e incentivo,

mesmo que muitas vezes em silêncio.

Não tenho palavras para agradecer a tudo que fizeram e fazem por mim.

Obrigada!

Ao meu namorado Augusto,

Por todo amor, apoio, paciência e compreensão.

$\mathcal{N a ̃ o ~ t e n h o ~ c o m o ~ a g r a d e c e r ~ a ~ t u d o ~ o ~ q u e ~ f a z e s ~ e m ~ m i n h a ~}$ vida, tornando-a todos os dias mais alegre e doce.

Aos seus pais, Beatriz e Edgar e sua irmã, Rafaela, pelo apoio, incentivo e momentos agradáveis que sempre tivemos. 
Ao Prof. Dr. Osny Ferreira Junior,

Agradeço pela valiosa e competente orientação deste trabalho, pelos valiosos ensinamentos e constante incentivo e apoio desde minha graduação e curso de mestrado.

Certamente propiciou meu crescimento humano $e$ científico.

Muito me honra considera-lo, além de mestre, um amigo.

Sempre terás minha admiração e respeito.

Muito obrigada!

À Faculdade de Odontologia de Bauru da Universidade de São Paulo, na pessoa de sua Diretora, Profa Dra. Maria Fidela de Lima Navarro.

À Comissão de Pós-graduação da Faculdade de Odontologia de Bauru, na pessoa de seu Presidente, Prof. Dr. José Carlos Pereira. 
Aos professores do Departamento de Estomatologia e Radiologia Dr. José Humberto Damante, Dra Ana Lúcia Álvares Capelloza, Dr. Luiz Eduardo Montenegro Chinellato, e Dr ${ }^{a}$ Izabel Regina Fischer Rubira-Bullen, pelo apoio e confiança em mim depositados, todos os ensinamentos transmitidos, pela constante disponibilidade e atenção que sempre me dispuseram.

Aos professores do Departamento de Cirurgia Dr. Eduardo Sant Ana, Dr. Júlio de Araújo Gurgel e Dr. Paulo Sérgio Perri de Carvalho pelos valiosos ensinamentos e experiência transmitidos.

Ao Prof. Dr. José Mauro Granjeiro, pelos ensinamentos, pela atenção durante a elaboração do projeto de pesquisa e pelo fornecimento dos materiais.

Ao Prof. Dr. José Roberto Pereira Lauris, por toda orientação na realização da estatística deste trabalho. 
Ao Renato, meu colega de graduação e mestrado. Por toda amizade, paciência, disponibilidade e ajuda durante as cirurgias realizadas, meu profundo agradecimento!

Aos meus demais colegas da turma de mestrado Carla, Ligia, Márcia e Marcelo Zanda. Por toda amizade, companheirismo e ensinamentos, fazendo nosso convívio sempre muito prazeroso.

Aos colegas do curso de doutorado, Cláudio, Flávio, Luiz Fernando, Fernando, Eduardo e Cássia.

Aos amigos Fernanda, José Gustavo, Thiemi, Josiane, Camila, Letícia, Álvaro, Aline e Thaís, pela amizade, incentivo e apoio em vários momentos da minha vida. $\mathcal{A}$ amizade de vocês é um presente para mim.

Aos funcionários dos Departamentos de Estomatologia, Radiologia e Cirurgia, Fernanda, Roberto, Marília, Josieli, Camila, Tânia, David, Reinaldo e Regina, pela constante atenção, ajuda e prestatividade que sempre tiveram comigo. 
Ao Marcos, funcionário da Periodontia, pela impecável confecção dos posicionadores radiográficos utilizados nesta pesquisa.

A todos os funcionários da Biblioteca da Faculdade de Odontologia de Bauru.

A todos os pacientes da pesquisa.

E enfim, a todos que, de alguma forma, contribuíram para a realização deste trabalho,

os meus mais verdadeiros agradecimentos! 
SUMÁRIO

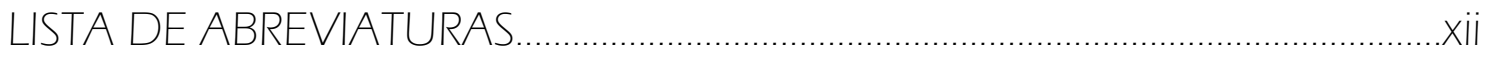

LISTA DE FIGURAS

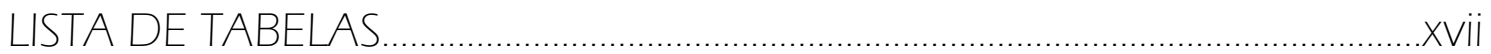

RESUMO

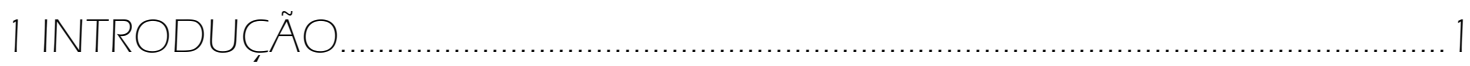

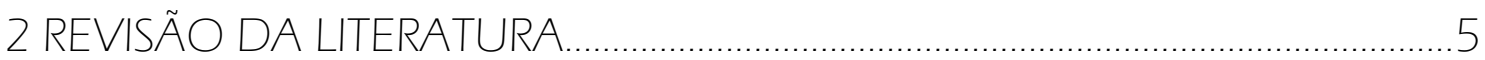

З PROPOSIÇÃO

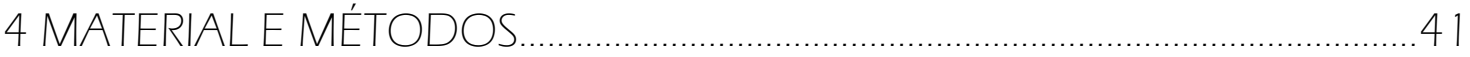

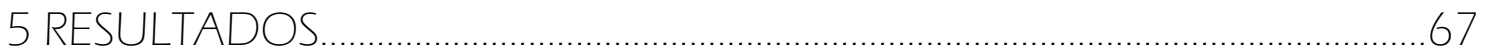

6 DISCUSSÃO

7 CONCLUSÕES

ANEXOS

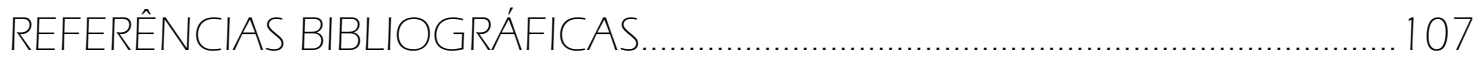

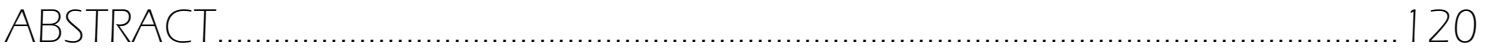




\section{LISTA DE ABREVIATURAS}

BMP: bone morphogenetic proteins (proteína morfogenéticas óssea)

DFDBA: desmineralized freeze-dried bone allogafts losso alógeno liofilizado desmineralizado|

EGF: fator de crescimento epidermal

FDBA: freeze-dried bone allogafts (osso alógeno liofilizado)

FGF: fator de crescimento de fibroblasto

HCl: ácido clorídrico

HA: hidroxiapatita

IGF: fator de crescimento similar à insulina

NIH: National Institute of Health (Instituto Nacional de Sáude)

RDD: radiografia digital direta

TGF- $\beta$ : fator de crescimento de transformação ß 


\section{LISTA DE FIGURAS}

Figura 4.1:

Radiografia panorâmica selecionada.

42

Figura 4.2:

Material utilizado - Osso bovino orgânico + inorgânico

+ Colágeno + BMP (Gen-tech $®)$. . . . 45

Figura 4.3:

Material utilizado - Membrana de cortical óssea bovina liofilizada (Gen-Derm®)...... 45

Figura 4.4:

Bloco de mordida.. 46

Figura 4.5:

Sensor adaptado ao bloco de mordida em acrílico. 46

Figura 4.6:

Embalagem dos posicionadores RINN - XCP.

Figura 4.7:

Os tipos de posicionadores e suas aplicações...

Figura 4.8:

Posicionador RINN-XCP para pré-molares

e

molares. ...47

Figura 4.9:

Posicionador com o bloco de mordida adaptado...

Figura 4.10:

Resina Duralay.. .48

Figura 4.11:

Bloco de mordia com resina Duralay... .49 
Figura 4.30:

Arquivo do paciente contendo as imagens radiográficas. 64

Figura 4.31: Sensor adaptado ao posicionador radiográfico com registro oclusal........ 
Figura 5.3:

Evolução da distância radiográfica da crista óssea alveolar à junção amelo-cementária na distal dos segundos molares inferiores, segundo tempo

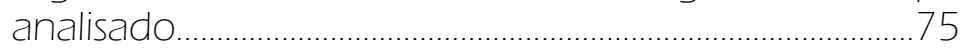

Figura 5.4:

Evolução da densidade radiográfica dos alvéolos dos terceiros molares inferiores. 


\section{LISTA DE TABELAS}

Tabela 5.1:

Resultados obtidos quanto a concordância intraexaminador nas medidas de altura da crista óssea à junção amelo-cementária. Teste "t" Pareado e Erro de Dalberg em mm. 71

Tabela 5.2:

Resultados obtidos quanto a concordância intraexaminador nas medidas de densidade óssea. Teste " $\mathrm{t}$ " Pareado e Erro de Dalberg em valores de pixel.

Tabela 5.3:

Resultados obtidos quanto a correlação das medidas intra-examinador para distância da crista óssea à junção amelo-cementária. Coeficiente de Correlação de Pearson.

Tabela 5.4:

Resultados obtidos quanto a correlação das medidas intra-examinador na avaliação da densidade óssea. Coeficiente de Correlacão de Pearson. 73

Tabela 5.5:

Dados gerais obtidos da distância radiográfica da crista óssea alveolar à junção amelo-cementária. 74

Tabela 5.6:

Resultados obtidos da distância radiográfica da crista óssea alveolar à junção amelo-cementária. Análise de Variância a 2 Critérios (ANOVA). 75

Tabela 5.7:

Resultados obtidos da distância radiográfica da crista óssea alveolar à junção amelo-cementária ao longo do tempo. Teste de Tukey. 
Tabela 5.8:

Resultados obtidos da distância radiográfica da crista óssea alveolar à junção amelo-cementária. Comparação entre variações, Teste "t" Pareado após 2 meses.

Tabela 5.9:

Resultados obtidos da distância radiográfica da crista óssea alveolar à junção amelo-cementária. Comparação entre variações, Teste " $t$ " Pareado após 6 meses.

Tabela 5.10:

Dados gerais obtidos da densidade óssea radiográfica. 78

Tabela 5.11:

Resultados densidade óssea radiográfica. Análise de Variância a 2 Critérios (ANOVA) 79

Tabela 5.12:

Resultados obtidos da densidade óssea radiográfica ao longo do tempo. Teste de Tukey. 80

Tabela 5.13:

Resultados obtidos da densidade óssea radiográfica entre grupos. Teste de Tukey.

Tabela 5.14:

Resultados obtidos da densidade óssea radiográfica. Comparação entre variações, Teste " $t$ " Pareado após 2 meses.

Tabela 5. 15:

Resultados obtidos da densidade óssea radiográfica. Comparação entre variações, Teste "t" Pareado após 6 meses. 
$\underline{\text { Resumo }}$ 


\section{$\underline{\text { RESUMO }}$}

O propósito deste trabalho foi avaliar uma associação de matriz óssea bovina inorgânica, orgânica, colágeno e BMP (Gen-tech®) como material de enxerto em alvéolos de terceiros molares inferiores nãoirrompidos. A amostra constituiu-se de 39 pacientes entre 15 e 25 anos de idade que possuíam terceiros molares inferiores não-irrompidos bilateralmente, com indicação para extração e que se apresentavam de maneira simétrica com relação ao seu posicionamento. Os dentes foram extraídos, sendo um dos lados mantido apenas com coágulo Igrupo controle) e o outro lado (grupo experimental) recebeu o enxerto do material proposto e membrana de cortical óssea bovina desmineralizada (Gen-derm®). A análise constituiu de medidas da distância da crista óssea alveolar à junção amelo-cementária e da densidade radiográfica. Esses exames foram realizados no trans-operatório do grupo experimental e pós-operatório imediato, pós-operatório de 60 e 180 dias do ambos os grupos, através de radiografias periapicais digitais diretas. Os resultados demonstraram que houve uma diminuição na medida da distância da crista óssea alveolar à junção amelo-cementária significante ao longo dos períodos analisados, porém não houve diferenças entre grupos. Com relação à medida de densidade, houve um aumento significante ao longo do tempo nos dois grupos e significantemente maior no grupo experimental, porém não significante, comparando os grupos nos períodos de tempo separadamente. Entretanto, não se pode afirmar que esse aumento se deve a neoformação óssea ou a radiopacidade do material ainda presente. Os resultados mostram que 
há melhora nas condições periodontais nos segundos molares adjacentes após a extração dos terceiros molares inferiores nãoirrompidos e sugere que o material foi bem aceito na região e teve comportamento semelhante ao coágulo. 


$$
1 \text { - Introdução }
$$




\section{INTRODUCÃO}

Há evidências de que se tem intensificado o número de extrações de terceiros molares não-irrompidos dentro da Odontologia. (RALLEY, CHAPNICK \& BAKER ${ }^{58}, 1977$, BATAINEH, ALBASHAIREH \& HAZZA ' A $^{58}$, 2002, KUGELBERG et al ${ }^{35}, 19851$

Algumas razões podem explicar esse fato. Dentre elas estão, o maior acesso da população às radiografias panorâmicas que diagnosticam dentes não-irrompidos, a informações sobre os dentes nãoirrompidos, e a Ortodontia, que em geral, indica as extrações desses dentes.

Os terceiros molares são os dentes com maior incidência de não irrompimento e sua extração é um dos procedimentos cirúrgicos mais comumente realizados pelos cirurgiões dentistas. (ROBINSON ${ }^{59}, 1994$, TETSCH \& WAGNER $\left.{ }^{70}, 1985\right)$

Esses dentes podem não irromper em função do comprimento inadequado dos maxilares e do pouco espaço para o irrompimento, isto é, o comprimento total do arco ósseo alveolar é menor do que o arco dentário. A redução gradual do tamanho da mandíbula e da maxila, dentro do processo de evolução, é um dos fatores que podem justificar a existência de dentes não irrompidos (ARCHER', 1975, RALLEY58, 1977. QUEIROZ \& LINO57, 20011 .

O número de extrações tem crescido principalmente como medida de prevenção de transtornos relacionados ao não-irrompimento ou ao semi-irrompimento desse dente. (PETERSON ${ }^{53}$, 1996, PUNWUTIKORN, WAIKAKUL \& OCHAREON ${ }^{56}, 1999$, BATAINEH, ALBASHAIREH \& HAZZA ' $A^{5}, 2002$, QUEIROZ \& LINO57, $\left.2001, \mathrm{NIH}^{46}, 1980\right)$. 
Um dos principais transtornos relacionados aos terceiros molares é o defeito ósseo periodontal na distal do segundo molar adjacente (PETERSON ${ }^{53}, 1996$, ESLAMI, SADEGHI \& VAN SWOL ${ }^{17}, 1985$, PENG et $\mathrm{al}^{52}, 2001$, KUGELBERG et al ${ }^{34,35,36,37}, 1985,1986,1990,1991$, MARMARY et $\left.\mathrm{al}^{42}, 1996\right)$ e diversas técnicas têm sido preconizadas para que haja um reparo ideal nessa região após a extração dos terceiros molares. IGIGLIO20, 2003, PETRI \& WILSON ${ }^{54}$, 1993, DODSON ${ }^{15}, 1996$, THRONDSON \& SEXTON ${ }^{71}, 20021$.

Terapias periodontais têm sido pospostas para minimizar esse problema como raspagem do cemento contaminado, aplicação de condicionadores ácidos e também técnicas de regeneração óssea guiada através do uso de membranas e enxertos ósseos ${ }^{15,20,54,71}$.

Outro problema inerente à Cirurgia buco-maxilofacial é a dificuldade de reparação de feridas ósseas (CALIXTO et al ${ }^{10}, 2001$ ), e no que diz respeito à alvéolos dentários, a dificuldade de manutenção de altura, espessura e qualidade óssea para propiciar uma adequada colocação de implantes e / ou reabilitação protética. (CAMARGO et al?', 2000).

Tendo isso em vista, tem se intensificado as pesquisas para o desenvolvimento de materiais que apresentem características adequadas de biocompatibilidade e osteointegração. Atualmente existem diversas opções de biomateriais que servem como substitutos ao osso autógeno, com propriedades osteoindutoras e osteocondutoras.

A área de alvéolo de terceiros molares inferiores tem sido pesquisada mais recentemente como área receptora de biomateriais devido à necessidade de prevenção de defeitos ósseos na distal dos segundos molares, como já mencionado anteriormente, e também por 
ser uma área que possibilita padronização para estudos de biomaterias implantados em alvéolos. 
2 - Revisão da Literatura 


\section{REVISÃO DA LITERATURA}

Com a intenção de facilitar a leitura da revista da literatura, o capítulo está dividido em:

2.1 - Os Terceiros Molares Não-irrompidos

2.2 - Os Biomaterias

2.2.1 - O Uso de Biomaterias na Odontologia

2.2.2 - A Utilização de Biomaterias em Alvéolos de Terceiros molares

2.3 - Avaliação pós-operatória e Radiologia digital.

\section{1 - Os Terceiros Molares Não-irrompidos}

Dente não irrompido é um órgão dentário que, mesmo completamente desenvolvido, não irrompeu na cavidade bucal, encontrando-se, portanto, totalmente coberto por tecido ósseo e/ou por mucosa. Os terceiros molares são os dentes que apresentam maior freqüência de não irrompimento (ROBINSON ${ }^{59}$, 1994). TETSCH \& WAGNER ${ }^{70}$, em 1985, relataram que, em pacientes com mais de 20 anos de idade, 17\% possuíam pelo menos um dente não irrompido e que, 
entre esses, cerca de 80\% eram terceiros molares. Isso se deve ao fato de serem os últimos dentes a completar sua formação e, cronologicamente, os últimos a realizarem o processo de irrompimento.

Esses dentes podem não irromper em função do comprimento inadequado dos maxilares e do pouco espaço para o irrompimento, isto é, o comprimento total do arco ósseo alveolar é menor do que o arco dentário. A redução gradual do tamanho da mandíbula e da maxila, dentro do processo de evolução, é um dos fatores que podem justificar a existência de dentes não irrompidos (ARCHER', 1975 e RALLEY58, 1977).

Ouando não irrompidos, os terceiros molares são potencialmente capazes de causar transtornos e prejuízos à saúde bucal do indivíduo, risco que se transforma em indicação para exodontia.

As principais indicações para exodontia de terceiros molares nãoirrompidos são prevenção de doença periodontal, pericoronarite, cárie, reabsorção radicular, cistos e tumores, fratura da mandíbula e facilitação de tratamentos ortodônticos. (PETERSON $\left.{ }^{53}, 1996\right)$.

Dentre as razões apara indicações da extração, algumas geram intensa controvérsia. No sentido de minimizar as discordâncias, em 1980, o National Institute of Health $\left(\mathrm{NIH}^{46}\right)$, publicou um consenso das indicações para extração de terceiros molares, o qual vem sendo usado como guia até os dias de hoje.

Os critérios determinados pelo $\mathrm{NIH}^{46}$, que também encontram apoio na literatura são: infecção no dente ou periodonto adjacente ${ }^{5,56,57}$, cáries não-restauráveis no terceiro molar ou na distal do segundo molar adjacente $5,56,57$, presença de cistos e tumores ${ }^{57}$, destruição de dentes ou tecido ósseo adjacente 5,56,57. Existe também uma tentativa de consenso de que o não-irrompimento causado pelo mau posicionamento do 
terceiro molar, por si só, é uma condição anormal que justifica a extração, mesmo de terceiros molares assintomáticos $\left(\mathrm{NIH}^{46}, 1980\right)$.

A idade média de irrompimento, para terceiros molares inferiores é por volta dos 20 anos, podendo acontecer até os 25 anos (PETERSON ${ }^{53}$, $1996)$.

Como regra geral, os terceiros molares não irrompidos devem ser extraídos na idade jovem (KUGELBERG et al ${ }^{34,37}, 1990$ e 1991 e PETERSON ${ }^{53}$, 1996). Afirma-se que a extração precoce, profilática, reduz a morbidade pós-operatória, evitando a doença periodontal e possibilitando melhor reparo e aderência da mucosa gengival ao segundo molar adjacente ${ }^{46,53}$.

O período considerando ideal é após a formação do primeiro terço da raiz e antes da formação do segundo terço dela, o que normalmente ocorre no final da adolescência, entre 16 e 18 anos de idade. (ASH, COSTICH \& HAYWARD ${ }^{4}, 1962$, OSBORNE, SNYDER \& TEMPEL ${ }^{49}, 1982$, PETERSON $\left.{ }^{53}, 1996\right)$.

Os pacientes que tem seus terceiros molares extraidos após os 25 anos têm menor chance de que ocorra diminuição da bolsa intra-óssea na distal do segundo molar, bem como reparo ideal. Também se torna mais difícil a exodontia com o avançar da idade, pois além de o osso tornar-se mais mineralizado e menos resiliente, com o tempo, os pacientes com mais idade tem um processo de reparo menos favorável e a incidência de alterações sistêmicas se torna maior ${ }^{46,53}$.

segundo GREGORI 22 , em 1996, a capacidade de reparação das lesões causadas por traumatismos em suas estruturas orgânicas é inerente ao ser vivo, principalmente em espécies animais. É devido a essa capacidade de reparação que podemos fazer uso da terapêutica 
cirúrgica. Esse fato justifica a importância de buscar novas informações que acompanhem a reparação estrutural, um fator com intensa participação nos mecanismos de defesa e da própria vida do organismo.

SHAFER ${ }^{61}$ et al, em 1985, observaram que depois da remoção do dente, o sangue que preenche o alvéolo coagula, com as hemáceas sendo aprisionadas numa rede de fibrina, e as extremidades dos vasos sanguíneos no ligamento periodontal rompidos ficam obliteradas. 0 coágulo sanguíneo é importante para a cicatrização de forma que, se ele for deslocado, essa pode ser bastante retardada e extremamente dolorosa. Há vasodilatação e ingurgitação dos vasos sanguíneos nos restos do ligamento periodontal e mobilização de leucócitos na área à volta do coágulo. É importante reconhecer que o colapso da gengiva sem suporte sobre a abertura da ferida de uma extração recente ajuda bastante a manter a posição do coágulo.

Na primeira semana após a extração, é evidente a proliferação de fibroblastos provenientes das células do tecido conjuntivo dos restos do ligamento periodontal. Esses fibroblastos começam a crescer para dentro e à volta do coágulobl.

Durante a segunda semana após a extração do dente, o coágulo sanguíneo torna-se organizado pela invasão de fibroblastos que crescem sobre a rede de fibrina. Nesta fase, novos capilares penetram no centro do coágulo, e os restos do ligamento periodontal sofrem degeneração gradual e não são mais reconhecíveis; as paredes do alvéolo aparecem, agora, ligeiramente irregulares e, em alguns casos, podem ser observadas trabéculas de tecido osteóide projetando-se da parede do alvéolo ${ }^{61}$. 
Na terceira semana, o coágulo primitivo apresenta-se quase que completamente organizado pelo tecido de granulação em maturação. Em toda a periferia da ferida, a partir da parede do alvéolo, formam-se trabéculas muito jovens de osteóide ou osso não-mineralizado. Este osso é formado por osteoblastos derivados de células pluripotentes do ligamento periodontal que adquirem função osteogênica ${ }^{61}$.

Na quarta semana após a extração, inicia-se o estágio final da cicatrização da ferida, no qual há deposição contínua e reabsorção moderada do osso que preenche o alvéolo; essa remodelação continuará por mais várias semanas ${ }^{61}$.

Porém devido à contaminação prévia através do acúmulo de placa há uma dificuldade de reparo após exodontia dos terceiros molares, principalmente no que diz respeito a diminuição da reabsorção óssea na região distal do segundo molar adjacente e aderência da mucosa gengival (PETERSON ${ }^{53}, 1996$ ).

Em estudo retrospectivo, ESLAMI, SADEGHI \& VAN SWOL ${ }^{17} \mathrm{em}$ 1985, encontraram um índice de 16\% de defeitos ósseos na distal do segundo molar após exodontia do terceiro molar inferior adjacente.

Posteriormente, em 2001, PENG et al ${ }^{52}$ encontraram maior índice de defeitos ósseos na distal de segundos molares após exodontia de terceiros molares inferiores comparado aos segundos molares controles, onde havia agenesia de terceiros molares.

Em uma série de estudos, KUGELBERG et al $14,35,36,37$ acompanharam os resultados pós-operatórios de seus pacientes por um período de quatro anos. Em seu primeiro trabalho, de 1985, KUGELBERG et al ${ }^{35}$ analisaram parâmetros clínicos e radiográficos após dois anos da extração dos terceiros molares inferiores de 215 pacientes. Com relação 
aos defeitos ósseos na distal dos segundos molares que foram registrados no pré-operatório e após dois anos, concluiu que boa parte dos defeitos encontrados no pré-operatório mantiveram-se ou aumentaram nesse período, principalmente nos pacientes acima de 26 anos de idade.

MARMARY et $\mathrm{al}^{42}$, em 1996, em seus estudos, dividiram 60 pacientes que possuíam terceiros molares inferiores não-irrompidos em dois grupos etários, de 20 a 29 anos e de 30 a 50 anos. Após comparação radiográfica pré e pós-operatória (seis meses e quatro anos após a cirurgial da altura da crista óssea alveolar na distal dos segundos molares, concluíram que houve diminuição dos defeitos ósseos em ambos os grupos, porém foi significativamente menor no grupo mais velho.

Em 1990, KUGELBERG ${ }^{34}$ publicou a continuação de seu trabalho, onde avaliou o reparo periodontal quatro anos após a cirurgia realizada em 51 pacientes de sua amostra inicial. Clinicamente, através da avaliação de índice de placa, índice gengival e sondagem, não encontrou diferenças estatisticamente significantes. No período entre dois e quatro anos não houve alterações na altura da crista óssea alveolar na distal dos segundos molares.

Em outro estudo, KUGELBERG et al ${ }^{37}$, em 1991, dividiram os pacientes em grupos menores de 20 anos e maiores de 30 anos e relataram que defeitos ósseos pré-operatórios maiores que $4 \mathrm{~mm}$ diminuíram apenas no grupo jovem após 1 ano. Ainda neste grupo, a presença de placa bacteriana e a ocorrência de sangramento gengival antes da cirurgia não interferiram no reparo, ao contrário do grupo de pacientes mais velhos. 
GIGLIO 20, em 2003, avaliou dois métodos de tratamento na raiz distal dos segundos molares após extração dos terceiros molares inferiores não-irrompidos de 30 pacientes. No grupo controle, realizavase apenas raspagem com cureta e, no grupo experimental, realizava-se raspagem e aplicação de ácido cítrico a 50\% (pH 1) com tetraciclina. Após avaliação do índice gengival, índice de placa, profundidade de sondagem e medidas entre a crista óssea alveolar e a junção amelocementária em radiografias interproximais digitais nos períodos de três e seis meses pós-operatório, o autor concluiu que os resultados demonstraram que todos os critérios avaliados apresentaram melhora após a extração dos dentes não irrompidos. Porém, em todas as variáveis estudadas não houve diferenças estatisticamente significantes entre os grupos experimental e controle.

\section{2 - Os Biomateriais}

\subsection{1 - O Uso de Biomaterias na Odontologia}

Entre os problemas de difícil solução, na Medicina e Odontologia, incluem-se os defeitos ósseos de grandes dimensões que, deixadas ao seu livre curso levariam mais tempo para reparar-se. (CALIXTO et al ${ }^{10}$, 20011

No caso de alvéolos de terceiros molares inferiores, há uma dificuldade no reparo, principalmente na região distal do segundo molar adjacente (THRONDSON \& SEXTON ${ }^{71}, 2002$, DODSON $^{15}$ 1996) e também em sua totalidade, devido ao tamanho da ferida cirúrgica e a 
dificuldade de manutenção do coágulo e constantes infecções.(GÜLALDI et al ${ }^{24}$, 1998, PETRI \& WILSON ${ }^{54}$, 1993)

Há ainda o problema de reabsorção óssea após a exodontia, causando uma deficiência de altura óssea, que é um problema clínico em dois aspectos, pois cria problemas estéticos para confecção de próteses convencionais ou sobre implantes e pode dificultar ou impossibilitar a colocação de implantes se o nível ósseo não for mantido e também dificultar a estabilidade de próteses totais. (CAMARGO et al', 2000)

A região dos terceiros molares, geralmente não recebe implantes, a não ser em casos específicos, porém serve como parâmetro para avaliação de outras regiões.

Em situações dessa natureza pode-se fazer uso de biomateriais para reconstrução, substituição ou preenchimento dos defeitos. Tem sido feito também intenso uso de biomaterias para preenchimentos de defeitos ósseos periodontais, mostrando resultados positivos no ganho de altura óssea nesses sítios. Tendo isso em vista, tem se intensificado as pesquisas para o desenvolvimento de materiais que apresentem características adequadas de biocompatibilidade e osteointegração (TAGA ${ }^{65}$, 1996, MASTERS ${ }^{43}$, 1988, CALIXTO et al $\left.{ }^{10}, 2001\right) .0$ preenchimento de alvéolos dos terceiros molares com biomaterias poderia prevenir também a manutenção de defeitos ósseos na região distal dos segundos molares.

O requisito mínimo para a implantação de materiais em tecidos vivos é a biocompatibilidade. Qualquer material estranho colocado no interior de tecidos vivos provoca uma resposta, e não é a resposta em si, mas sua extensão, intensidade e duração que determinam a 
biocompatibilidade, ou seja, um estado de mútua coexistência entre um material e o ambiente fisiológico, sem que um exerça efeito desconfortável sobre o outro ${ }^{10}$. No caso dos implantes intra-ósseos, espera-se que o material implantado seja capaz de estabelecer um contato direto com o tecido ósseo reparacional (osteointegração direta). Os biomateriais podem também estabelecer com o osso circundante uma integração direta fibro-óssea, quando uma cápsula fibrosa se interpõe entre eles e a superfície do osso, o que é aceitável apenas nos estágios iniciais pós-implantação por ser desfavorável à estabilidade dos enxertos em longo prazo ${ }^{10}$.

Os biomateriais são classificados em osteoindutores e osteocondutores.

Os osteoindutores são aqueles que quando colocados em uma ferida óssea auxiliam a reparação da mesma, induzindo a formação de novo tecido ósseo por um mecanismo no qual células mesenquimais indiferenciadas são diferenciadas em osteoblastos (TAGA $\left.{ }^{65}, 1996\right)$.

Os osteocondutores são aqueles que, quando colocados em uma ferida óssea, preenchem a cavidade óssea guiando o tecido ósseo na sua neoformação. O material osteocondutor pode ser englobado pelo tecido ósseo neoformado passando a fazer parte do novo tecido ${ }^{65}$.

A diferença fundamental entre ambos é que um é biologicamente ativo e outro serve apenas como material de preenchimento ${ }^{65}$.

Dentre os materiais osteoindutores, pode-se destacar:

Osso autógeno: sem dúvida é o material padrão ouro de enxerto devido ao fato de inexistir a possibilidade de rejeição, pois o material é 
obtido do tecido ósseo do próprio indivíduo. Ele pode ser obtido através de alvéolo cirúrgico provocado ou através da retirada de fragmentos de osso de regiões distantes como osso mentoniano, ângulo da mandíbula túber da maxila, crista ilíaca e calota craniana. $O$ fator limitante é a necessidade de cirurgias traumáticas e a quantidade limitada de material disponivel (TAGA $\left.{ }^{65}, 1996\right)$.

Osso alógeno: é comercializada nos Estados Unidos e conhecida mundialmente pela sigla FDBA (freeze-dried bone allografts - osso alógeno liofilizado) e o desmineralizado DFDBA (desmineralized freezedried bone allografts - osso alógeno liofilizado desmineralizado), que significa osso desmineralizado e liofilizado. O processo de trituração do osso para sua desmineralização permite a obtenção de pó de osso com diferentes granulometrias. É indicada para todas as situações de perda óssea. No Brasil é proibida a comercialização de material de procedência humana. Além disso, o custo para manutenção do banco de ossos é muito elevado, há pouca disponibilidade e há riscos de contaminação por diversas doenças (TAGA $\left.{ }^{65}, 1996\right)$.

Matriz orgânica de osso bovino: desprovida de células, lipídios e proteínas imunogênicas e constituída basicamente de colágeno tipo I. É obtida a partir de osso cortical bovino com 12 a 15 meses de idade e totalmente livre de osso medular, que é rapidamente lavado com peróxido de hidrogênio para retirada de sangue tecidual. Após isso a gordura presente é retirada através de lavagem com uma mistura de etanol-acetona a 4 graus centígrados em câmara fria. $\bigcirc$ excesso do solvente é removido através de lavagem com água deionizada e o osso 
cortical é seco a $37^{\circ} \mathrm{C}$, e posteriormente triturado em partículas com granulação média de 500 micrômetros. $\bigcirc$ pó é desmineralizado numa câmara fria com lavagens sucessivas de $\mathrm{HCl}$. A neutralização é realizada através de várias lavagens com água deionizada gelada até que o pH atinja o valor 7. A seguir o material é seco pelo processo de liofilização, que desidrata o material a $60^{\circ} \mathrm{C}$, sob vácuo, impedindo, desta forma, a desnaturação das proteínas da matriz orgânica do osso, preservando seu princípio ativo.

Do ponto de vista imunológico, ele não induz o aperfeiçoamento de células linfocitárias no teste de biocompatibilidade, além disso, é totalmente reabsorvido após 90 dias e tem ação osteoindutora devido a presença de proteínas e colágeno. As vantagens deste tipo de material é que vem de uma fonte praticamente inesgotável e com custo relativamente barato. (TAGA $\left.{ }^{65}, 1996\right)$ Pode ser encontrado no mercado com a marca Gen-ox® - Matriz.Orgânica de Osso Bovino Liofilizado (Baumer S.A ${ }^{19}$ ).

TAGA et al ${ }^{67}$, em 1997, avaliaram o reparo de defeito ósseo perene em crânios de cobaias com aplicação de Osseobond® Igrupo experimental) comparado a apenas coágulo (grupo controle) e encontram, no grupo controle, todos os defeitos preenchidos apenas por tecido fibroso quase que em toda lesão, mesmo nos períodos mais longos, de seis meses. Em alguns poucos casos foi possível notar um pequeno crescimento na borda óssea. Já no grupo experimental havia intenso processo de reparação óssea após seis meses, estando a maioria preenchidos quase que completamente por tecido ósseo organizado. Os autores concluíram que, a partir de resultados obtidos na pesquisa, a matriz liofilizada bovina tem capacidade de estimular a formação de 
novo tecido ósseo em sítio ortotópico de cobaias, reforçando as possibilidades de uso na clínica Odontológica.

GARCIA \& BARBOSA ${ }^{18}$, em 2000, em um estudo de enxerto com Osseobond® em calvárias de coelhos encontraram também um resultado microscópico satisfatório, havendo melhora no reparo ósseo.

Fatores de crescimento ósseo (BMP) ou proteínas morfogenéticas do osso: são proteínas encontradas em grande quantidade no osso em desenvolvimento e que ficam enclausuradas na matriz orgânica do osso após a completa maturação do mesmo, ligadas ao colágeno. Foram descobertas por URIST ${ }^{72}$ em 1965 e desde então mais de 15 já foram relacionadas à capacidade de induzir a formação óssea ectópica. Ela é capaz de induzir a síntese de matriz óssea através de quimiotaxia, proliferação e diferenciação celular de células mesequimais indiferenciadas em osteoblastos, tanto em regiões ortópicas e ectópicas, por ser um fator de crescimento. (TAGA ${ }^{65}, 1996$, TAGA et al ${ }^{68}, 2000 \mathrm{e}$ LINDSEY $\left.{ }^{4}, 2001\right)$.

Fatores de crescimento, ou moduladores da atividade celular, são peptídeos ou proteínas secretadas que estimulam ou inibem a divisão, diferenciação e migração celular e a expressão gênica. São divididos em super familias: IGF (fator de crescimento similar à insulina), TGF- $\beta$ (fator de crescimento de transformação), EGF (fator de crescimento epidermal), FGF (fator de crescimento de fibroblasto), PDGF (fator de crescimento derivado de plaquetas), entre outros. (LINDSEY ${ }^{41}, 2001$ ).

Os membros da família TGF- $\beta$, como a BMP, podem ser encontrados em muitos órgãos, mas estão armazenados, principalmente na matriz óssea e suas funções no reparo ósseo já foram comprovadas ${ }^{4}$. 
O processo de obtenção é praticamente o mesmo da matriz orgânica de osso e também possuem a mesma indicação.|(TAGA ${ }^{65}$, 1996). Inicialmente a extração e purificação em larga escala dessas proteínas ósseo-indutoras era dificultada pela necessidade de centenas de quilos de osso bovino para se obter microgramas de BMPs, porém, atualmente, é possivel sua produção ampla pela aplicação de técnicas de recombinação genética. (LINDSEY $\left.{ }^{41}, 2001\right)$.

Uma característica destas proteínas morfogenéticas é que elas necessitam de um veículo para sua liberação, que pode ser colágeno, fibrina do coágulo, sulfato de cálcio, matriz orgânica de osso, hidroxiapatita, ácido poliático ou poliglicólico. Pode ser encontrado com o nome comercial de Gen-proß) (Baumer S.A. ${ }^{19}$, TAGA $^{65}, 1996$, TAGA et $\mathrm{al}^{66}$ 2000).

TAGA et $\mathrm{al}^{66}$, em 2000, em estudo de caso clinico com preenchimento de alvéolo com mistura homogênea entre o "pool" de BMP bovina associada a hidroxiapatita absorvivel (B.M.P. ${ }^{\circ}$ - Dentoflex) e matriz orgânica de osso bovino liofilizado ( Osseobond® - Dentoflex), coberto por membrana absorvível de cortical óssea bovina liofilizada I Bioplate ${ }^{\circledR}$ - Dentoflex) observou resultados satisfatórios, havendo microscopicamente aceleração do processo de reparo, otimizando-o tanto quantitativa quanto qualitativamente.

Dentre os materiais osteocondutores, pode-se destacar:

Matriz óssea inorgânica: é completamente desprovida de proteínas e células, constituída de hidroxiapatita natural com carbonato e tem a 
vantagem de ser facilmente estocada por longo tempo e possui propriedades biológicas satisfatórias. Este material age como arcabouço para formação óssea e tem propriedades osteocondutivas. Pode ser encontrada sob apresentação comercial como Bio-Oss® (Osteohealth Co) ou Gen-Ox® - Osso Bovino Inorgânico Liofilizado (Baumer S.A. ${ }^{19}$ ).

Segundo ZITZMANN et $\mathrm{al}^{77}$, em 2001, o uso de Bio-Oss ${ }^{\circledR}$ em alvéolos humanos revelou propriedades osteocondutivas, sendo positivo o seu uso.

Em outro trabalho em 2002, INDOVINA JR \& MICHAEL ${ }^{29}$, comparando Bio-Oss® com dois tipos de sulfato de cálcio e alvéolo com coagulo, encontrou após dois meses resultados semelhantes entre o coagulo e o Bio-Oss®, e não houve reabsorção dos outros materiais.

ARTZI, TAL \& DAYAN ${ }^{2,3}$, em 2000 e 2001 pesquisaram o comportamento histomorfométrico e histoquímico do Bio-Oss $®$ em alvéolos humanos e observaram um consistente padrão de neoformação óssea, reabsorção de parte do material, havendo uma intensa interação do material com o tecido, considerando-o biocompatível, biodegradável e osteocondutor.

CARMAGNOLA, ADRIAENS \& BERGLUNDH'11, em 2003 compararam microscopicamente alvéolos humanos preenchidos apenas por coágulo após 1 a 15 anos, utilizando membrana Bio-Gideß após 4 meses e com aplicação de Bio-Oss ${ }^{\circledR}$ e Bio-Gide® após 7 meses e encontraram os seguintes resultados: nos grupos sem enxerto ósseo havia osso mineralizado e medular nos dois grupos, sendo que no de 1 a 15 anos havia grande quantidade de osso cortical e no de 4 meses maior presença de osso lamelar e medular. Já no grupo com Bio-Oss® havia 
após 7 meses presença de partículas, que eram circundadas por pequenas quantidades de osso cortical e tecido conjuntivo. Havia aproximadamente 26\% de osso lamelar, 8,4\% de osso cortical, 26,2\% de medular e 18,1\% de partículas de Bio-Oss®, sendo que 40\% dessas partículas estavam em contato com tecido ósseo neoformado.

Sulfato de cálcio: é o mais antigo dos biomateriais, sendo o principal componente do gesso paris. É bem tolerado pelo organismo, mas rapidamente reabsorvido (15 dias), tempo insuficiente para que ocorra neoformação óssea. (TAGA 65 , 1996)

Biocerâmicas: existem alguns tipos de biocerâmicas: Óxido de Alumínio e Óxido de Titânio, o Fosfato Beta-tricálcio e o Vidro Bioativo como o BioGran® (Orthovita Malvern, Penn) (THRONDSON \& SEXTON ${ }^{71}, 2002$ e MASTERS ${ }^{43}, 19881$.

$\bigcirc$ fosfato beta tricalcio é um excelente biomaterial, com total biocompatibilidade, mas tem o inconveniente de ser rapidamente reabsorvido, não acompanhando a neoformação de novo tecido ósseo. (TAGA ${ }^{65}$, 1996) Nas cerâmicas há adesão óssea com as partículas, havendo interação do material com o osso, dependendo de sua superficie.

Polímeros: há dois tipos de polímeros sintéticos, os não reabsorvíveis e os reabsorvíveis. Os não reabsorvíveis são produzidos através de combinação de polimetilmetacrilato e hidrometilmetacrilato, adicionado de sulfato de bário que garante sua radiopacidade, possui bons resultados.(MASTERS $\left.{ }^{43}, 1988\right)$. 
CALIXTO et al' ${ }^{10}$, em 2001 , num estudo com aplicação de polímero de mamona floculado em alvéolo de ratos, através de analise de cortes histológicos concluiu que este material não obteve resultados satisfatórios, pois levou ao retardo do reparo ósseo.

Porém, o modelo de estudo do trabalho (alvéolo) não é o ideal para avaliar a efetividade do material, sendo necessários estudos com defeitos críticos.

Os reabsorvíveis: apresentados na forma de ácido poliglicólico e ácido poliático têm a característica de causar rápidas induções. O ácido poliático em forma de cubos tem sido utilizado em alvéolos para a manutenção da fibrina e prevenção de alveolite (MASTERS ${ }^{43}, 1988$ ).

NAIR \& SCHUG ${ }^{45}$, em 2004, estudaram em 18 pacientes a aplicação em alvéolos de polímeros a base de ácidos poliático e poliglicólicos na forma compacta e em grânulos, com controles fotográficos e radiográficos após um, três e seis meses. Após seis meses, houve biópsia com broca trefina para aplicação do implantes e analise histológica. Os reparos foram satisfatórios tanto clinicamente como radiograficamente, nos controles e houve biocompatibilidade histologicamente, porém, a forma compacta causou uma inicial descalcificação do processo alveolar e a em forma de grânulos obteve melhores resultados.

Colágeno: o tratamento químico dos grupamentos da cadeia lateral dos aminoácidos que o constituem permite dar ao colágeno a consistência e o formato que desejamos ao material. O colágeno está presente, até certo ponto, em quase todos os órgãos e serve para manter as células juntas em unidades discretas. Além de seu papel estrutural no 
tecido maduro, o colágeno tem um papel importante no desenvolvimento tecidual ${ }^{19}$. É totalmente biocompatível, porém, rapidamente reabsorvido pelo organismo através da colagenase.(TAGA ${ }^{65}$, 1996).É encontrado sob a marca comercial Gencolß (Baumer S.A. $\left.{ }^{19}\right)$, por exemplo.

Hidroxiapatita (HA) (Ca 10(PO4)6(O4)2): é o mais conhecido e eficaz dos biomateriais osteocondutores. É um sal de fosfato de cálcio com uma organização cristalina bastante complexa. Existem duas classes: reabsorvível e não reabsorvível.

A hidroxiapatita reabsorvível é indicada para casos em que se necessita que ocorra a substituição do material pelo tecido ósseo e freqüentemente é utilizada em associação à matriz orgânica do osso e membranas biológicas. É microgranular, não sinterizado e apresenta uma velocidade de reabsorção pelo organismo bastante lenta, cerca de 4 a 6 meses. Existem no mercado com o nome de Osteogen® (Park Dental Research Corp) (100 micrômetros) e a Biohapatita® (Dentoflex com. Ind.) ( 10 a 50 micrômetros).

A hidroxiapatita não-reabsorvível é indicada em casos cirúrgicos em que houve grande perda de tecido e necessita-se realizar um preenchimento de cavidade. Este tipo de hidroxiapatita sofre um processo de sinterização, levando a alterações nas propriedades cristalinas do material, sendo mais compacto, a superfície torna-se mais lisa e o material insolúvel. Existem vários tipos disponiveis no mercado: a microgranular (Periograft@, Interpore®) (Interpore 18008 Skypark Circle, Irvinell, indicada para preenchimento de cavidades ósseas; a 
macrogranular (HA-40®, Osteosynt $\AA$ (Einco Biomaterial Ltda) e Interpore 200® (Interpore 18008 Skypark Circle, Irvine), havendo as porosas e não porosas, sendo a Interpore $200 \circledR$ (Interpore 18008 Skypark Circle, Irvine) a mais conhecida e tem por finalidade permitir a invaginação dos vasos sanguíneos e do tecido em neoformação; e por último, a em forma de bloco, utilizada para aumento de mento, rebordo alveolar e outras regiões ósseas. (TAGA $\left.{ }^{65}, 1996\right)$.

Em estudo com implante de hidroxiapatita e hidroxiapatita com biofosfonato em alvéolos de 10 pacientes, comparando também com enxertos em caprinos, DENISSEN et al'14, em 2000, avaliaram densidade óssea em radiografias e analise microscópica após seis meses. Radiograficamente não houve diferença estatisticamente significante na densidade óssea ao longo do tempo. Na análise microscópica após 6 meses observaram neoformação óssea na forma de osteóide ou osso primário nas proximidades e nos poros do implante, porém esse osso estava ainda desorganizado.

Cimento de ionômero de vidro: apesar de ser utilizado em procedimentos restauradores, estudos têm mostrado que são materiais como bom potencial e propriedades osteogênicas.

BRENTEGANI, BOMBONATO \& CARVALHO' , em um estudo em 1997 utilizaram cimento de ionômero de vidro em alvéolos de ratos, com grupos de uma, três e seis semanas. Os resultados mostraram que houve progressiva neoformação óssea e diminuição de tecido conjuntivo nas áreas ao redor do material, e concluíram que o material é biocompatível, sendo progressivamente incorporado pelo osso alveolar e que pesquisas 
com períodos mais longos poderiam mostrar um reparo completo da lesão.

Há ainda outros biomateriais como:

Membranas biológicas: impedem mecanicamente a invaginação de tecido conjuntivo ou epitélio. São recomendadas quando se utiliza biomateriais osteoindutores ou osteocondutores, para maior eficácia do material. Existem basicamente dois tipos de membranas: as não absorviveis e as absorvíveis, sendo essas as mais utilizadas atualmente, compostas por colágeno, de ácido polilático ou poliglático e mais atualmente à base de osso cortical bovino desmineralizado, ou seja, composta basicamente de colágeno.(Gen-Derm®) (Baumer S.A. ${ }^{19}$, TAGA 65, 1996, HERCULANI et al"27, 2000).

Elas atuam como barreiras que impedem a migração de tecido conjuntivo e epitelial gengival para dentro da área em reparação, fenômeno muito freqüente após técnicas de tratamento periodontal (JOLY et al ${ }^{31}$, 2002). Devido à sua capacidade homeostática promove a estabilidade do coágulo (WANG, CLIMB \& EBER ${ }^{75}, 2002$ ) e do enxerto ósseo, impedindo seu extravasamento para o tecido mole.

OLIVEIRA et al' ${ }^{48}$, em 2004 avaliaram uma membrana de osso cortical bovino desmineralizado implantada em subcutâneo de ratos e concluíram que ela é bem tolerada pelo organismo, sendo absorvida no período de 30 a 60 dias por células inflamatórias mononucleadas e células gigantes multinucleadas, que desaparecem após esse período, podendo ser utilizada como barreira em técnicas cirúrgicas de regeneração tecidual guiada. 
Numa comparação entre enxertos de Osseobond® e Biohapatita ${ }^{\circledR}$ (DENTOFLEX COM. IND) em defeitos ósseos perenes em crânios de cobaias com e sem membrana, TAGA et all", em 2000 encontraram após 6 meses no grupo sem membrana lesão preenchida por tecido conjuntivo fibroso, fragmentos de matriz óssea em reabsorção e corpos arredondados de hidroxiapatita rodeado por células mononucleadas e gigantes multinucleadas, não havendo evolução após três meses. Já com grupo com utilização de membrana de osso cortical bovino liofilizado, havia intensa neoformação óssea levando quase que ao fechamento entre as bordas, as partículas de hidroxiapatita foram englobadas e aprisionadas pela nova matriz óssea. A partir desses resultados os autores concluíram que o uso de membrana recobrindo toda a área do defeito funciona como barreira contra a migração de células inflamatórias do tecido conjuntivo adjacente e de exudato contendo vários mediadores químicos da inflamação para dentro da lesão, impedindo, com isso, a formação de corpos maiores de hidroxiapatita, fibrose e reação tipo corpo estranho que favorece a fagocitose das partículas de hidroxiapatita por macrófagos e a criação de um ambiente favorável à angiogênese e à neoformação óssea.

Também em 2000, HERCULANI et al ${ }^{27}$ realizaram estudos em cobaias utilizando membrana de cortical óssea bovina (Gen-Derm®) comparando grupos apenas utilizando membrana e grupo onde utilizaram membrana e enxerto de matriz óssea bovina desmineralizada (Gen-Ox®) e grupo controle apenas com coágulo.

No grupo 1, onde utilizou-se apenas a membrana, encontraram absorção da membrana na maioria da amostra após 30 dias. A 
membrana em todos os casos apresentava-se totalmente absorvida após 3 meses e havia tecido ósseo neoformado nas bordas da lesão e após 6 meses havia intensa quantidade de tecido ósseo neoformado nas bordas da lesão migrando para a região central, onde ainda havia tecido conjuntivo denso ${ }^{27}$.

No grupo 2, onde utilizou-se a associação dos dois materiais, já havia presença de pequena quantidade de tecido ósseo neoformado após 30 dias. A membrana em todos os casos apresentava-se totalmente absorvida após 3 meses e as bordas da lesão apresentavam osso neoformado. No centro haviam matriz óssea liofilizada em processo de reabsorção.Após 6 meses os tecido ósseo neoformado estava tendendo a um arranjo compacto e em alguns casos havia completo fechamento da lesão ${ }^{27}$.

No grupo 3, onde havia apenas coágulo, em toda a amostra, a borda da lesão apresentava menor quantidade de osso neoformado do que nos grupos experimentais e o espaço da lesão estava preenchido por tecido denso, mesmo após 6 meses $^{27}$.

Os autores concluíram que a associação da membrana com o biomaterial levou a um maior efeito osteogênico e que o material auxiliam na manutenção da membrana.

Aglutinantes: à base de dextrana (polissacarídeo), permite aglutinar a matriz orgânica de osso e hidroxiapatita reabsorvível, obtendo-se um material com consistência de cimento cirúrgico resistente ao sangue e que também permite a moldagem perfeita da cavidade cirúrgica. $\bigcirc$ colágeno também tem a função de aglutinante quando utilizado com a BMP. (TAGA ${ }^{65}, 1996$ e BAUMER S.A. ${ }^{19}$ ) 
As vantagens de enxertos xenógenos incluem a livre disponibilidade de quantidade, a eliminação de outro sítio cirúrgico, anestesia, tempo cirúrgico reduzido, menor perda de sangue e menos complicações, sendo uma fonte abundante e altamente segura, já que o processo de tratamento pelos quais passam (liofilização, desmineralização e desproteinização) elimina qualquer risco de antigenicidade ou zoonoses.

Graças às propriedades desses materiais, foi criado o Gen-Techß, que é a associação de matriz óssea orgânica cortical e inorgânica medular, "pool” de BMPs e colágeno, que é produzido pela Baumer S.A. 19 (Mogi Mirim, Brasil, RMS: 103.455.0000 1), ou seja, uma mistura de Genox® orgânico, inorgânico, Gen-col® e Gen-pro®, que foi utilizado no presente estudo aliado ao uso da membrana reabsorvível de osso cortical bovino liofilizado Gen-Derm®, também produzida pela Baumer S. A. ${ }^{19}$.

A vantagem da associação desses componentes é a ação osteocondutiva da matriz óssea inorgânica e osteoindutiva promovida pela matriz óssea orgânica e das BMPs, sendo o coágulo utilizado como aglutinante. Esse material é de fácil uso, bastando acrescentar o próprio sangue do paciente ou soro fisiológico no momento da aplicação ${ }^{19}$.

A despeito dos componentes individuais desse composto já terem sido testados isoladamente e do material estar disponível no mercado, seu efeito foi muito pouco avaliado em estudos científicos.

HIROTA, REZENDE \& GRANJEIRO ${ }^{28}$, em 2003 realizaram um estudo com Gen-tech® em levantamento de seio, comparando com 
enxerto autógeno em 10 pacientes. Após 6 meses foi realizado biópsia com broca trefina de $3,3 \mathrm{~mm}$ de diâmetro, que passaram por processamento histológico. Os autores observaram que havia quantidade similar de osso neoformado imaturo (29\%) e ausência de inflamação entre os dois tipos de enxerto (autógeno e biomaterial). Clinicamente, os dois grupos apresentaram ausência de sintomatologia, infecção e mobilidade dos implantes. Radiograficamente mostraram ausência de radioluscência periimplantar. Os autores concluíram que os resultados sugerem que o biomaterial em estudo é uma boa alternativa de tratamento aos enxertos autógenos e apresenta as vantagens da não limitação da quantidade óssea, melhora da morbidade pós-operatória, além do envolvimento de somente de um sítio cirúrgico.

SICCA ${ }^{62}$, em 2005, em dissertação de mestrado, avaliou o uso deste biomaterial em levantamento de seio maxilar de 18 coelhos, comparando com osso autógeno. Em controles após 2, 4 e 8 semanas obteve os seguintes resultados: Período de 2 semanas: houve início de neoformação óssea nas bordas dos seios maxilares envolvendo tanto as partículas de enxerto autógeno como partículas do componente inorgânico do biomaterial e havia presença de infiltrado inflamatório localizado ao redor do componente orgânico do biomaterial. Período de 4 semanas: não havia mais presença de infiltrado inflamatório em nenhum dos grupos e houve aposição óssea das bordas para o centro do seio maxilar. Período de 8 semanas: havia presença de tecido ósseo neoformado e tecido mielóide muito evidente nos dois grupos, no entanto o grupo experimental havia ampla presença do componente inorgânico do biomaterial e o grupo controle duas vezes mais presença de tecido mielóide. Concluiu-se que não houve diferenças com relação a 
neoformação óssea entre os grupos e que o Gen-tech® é potencialmente indicado como substituto de osso autógenos em cirurgias de levantamento de seio maxilar.

\subsection{2 - A Utilização de Biomaterias em Alvéolos de Terceiros} Molares

Como já mencionado anteriormente, é de grande preocupação dentro da Cirurgia buco-maxilofacial o reparo adequado após exodontia de terceiros molares, principalmente no que diz respeito ao reparo de defeitos ósseos na região distal do segundo molar adjacente. Diversos estudos têm sido feitos para tentar minimizar esse problema 17,34,35,37,42,52.

Além disso, há necessidade de um reparo ideal após exodontia de dentes em geral, principalmente, e no que diz respeito à quantidade de osso em altura e largura para posterior colocação de implantes e/ ou reabilitação protética (CAMARGO et al', 2000).

Com isso têm-se intensificado as pesquisas que buscam o uso de materiais auxiliares no reparo após exodontia e também substitutos para o osso autógeno.

A área de alvéolo de terceiros molares inferiores tem sido pesquisada mais recentemente devido à necessidade de prevenção e/ou correção de defeitos ósseos na distal dos segundos molares e também por ser uma área que possibilita padronização necessária para estudos desses materiais.

PETRI \& WILSON ${ }^{54}$, em 1993, avaliaram enxertos ósseos na região de terceiros molares inferiores de 25 pacientes usando osso alógeno desmineralizado associado a antibióticos, através do índice de infecção 
pós-operatória, densidade óssea radiográfica após seis meses e altura óssea após doze meses.

A avaliação pós-operatória foi quanto à presença de osteíte em até 10 dias e nenhum paciente apresentou esse quadro.

A densidade óssea foi obtida através do uso de um densitômetro que analisou a densidade do filme radiográfico nos sítios de extração por transmissão de lumens, e a densidade foi significantemente maior nos alvéolos experimentais.

A altura óssea após doze meses foram obtidas através de radiografias panorâmicas. Foram realizadas medidas lineares entre a face oclusal do segundo molar e a borda inferior da mandíbula. A altura óssea foi significantemente maior no lado experimental. No entanto a técnica não foi padronizada e não havia uma radiografia inicial para comparação, apenas as de seis e doze meses.

Outro estudo foi realizado por DODSON ${ }^{15}$, em 1996, avaliando os efeitos da colocação de enxertos de osso desmineralizado em pó em alvéolos de terceiros molares inferiores pós-extração, sem associação de membrana, em 7 pacientes. Seis meses após a cirurgia não encontrou diferenças entre os grupos experimental e controle no que diz respeito aos índices gengival e de placa, porém, a profundidade dos defeitos ósseos foi bem menor no grupo onde foi colocado o enxerto, de 3,3 para 0,6 mm em média, contra uma redução de 3,1 ara 1,4 mm em média no grupo controle. $\bigcirc$ autor conclui que o osso desmineralizado em pó pode prevenir a formação de defeitos ósseos na distal de segundos molares inferiores após a extração dos terceiros molares adjacentes não-irrompidos. 
Em 1998, GÜLALDI et al ${ }^{24}$ avaliou a capacidade de estimulação de células osteoblásticas em enxertos de osso alógeno em alvéolos de terceiros molares inferiores de 22 pacientes através de cintilografia. Foram realizados enxertos unilaterais após exodontia no grupo experimental e no grupo controle exodontia unilateral. Foram realizadas cintilografias nas fases dinâmica, e estática, bem como valores de pool sanguíneo, para avaliar atividade osteoblásticas. Houve maior pico de atividade na fase dinâmica com 7 dias do que com 28 dias no grupo experimental, porém não foi estatitiscamente significante. Nos estudos de pool sangüíneo também mostrou uma taxa maior nos 7 dias. Na fase estática houve significante aumento entre a primeira e a segunda cintilografia. Os autores concluíram que apesar dos resultados não terem sido estatisticamente significante, esse material aumentou a atividade osteoblástica no grupo experimental.

Mais recentemente, em 2002, THRONDSON \& SEXTON ${ }^{71}$ realizaram um estudo com 14 pacientes com idade superior a 25 anos, onde enxertaram BioGran ${ }^{\circledR}$ em alvéolos de terceiros molares inferiores não-irrompidos. Os autores realizaram controles clínicos pré e pósoperatório após três, seis e doze meses através de sondagem e controles radiográficos pré-operatórios e pós-operatórios após seis e doze meses através da distância entre a crista óssea alveolar e junção amelocementária. Os autores não encontraram uma diferença significante ao longo do tempo para ambos os lados tanto nas avaliações clínicas quanto radiográficas. Os níveis de adesão clinica foram significantemente maiores no lado experimental, porém não houve um significante aumento de formação óssea radiograficamente comparando os dois lados após 1 ano. 


\section{3 - Avaliação pós-operatória e Radiologia digital}

Um grande problema inerente à avaliação radiográfica da destruição óssea é a tendência de se subestimar a perda óssea na região interproximal, devido à superposição das margens corticais vestibular e lingual sobre o defeito (KUGELBERG et al/6, 1986). Outro problema encontrado na clínica e em pesquisas é a dificuldade de obtenção de radiografias padronizadas ao longo do tempo, nas avaliações periodontais (PLOTNICK ${ }^{55}, 1971$ ).

O índice de precisão, quando se comparam radiografias obtidas da mesma região em diferentes períodos, depende diretamente do grau de similaridade da projeção geométrica das radiografias, para que se possa afirmar que quaisquer diferenças encontradas representam realmente alterações ósseas, ou se são diferenças causadas pela técnica radiográfica não padronizada (CARPIO'12, 1994).

Diversos métodos para obtenção de radiografias padronizadas ao longo do tempo vêm sendo estudados (BISHOP et al', 1995, DUINKERKE et $\mathrm{al}^{16}, 1977$ e PLOTNICK,BERESIN \& SIMKINS55, 1971). Alguns destes utilizaram registro oclusal como meio de padronização.

KIRKEGAARD \& ZEUNER ${ }^{33}$, em 1974, lembram que estes posicionadores que utilizam moldagem da face oclusal de alguns dentes podem ter o inconveniente de que, durante o tratamento ou pesquisa, não poderá haver alterações oclusais nesses dentes, para que não haja prejuízo na padronização; porém, os autores concordam que pequenos ajustes na moldagem, quando necessários, não impossibilitam o emprego dos posicionadores. 
Já, KUGELBERG et al ${ }^{36} \mathrm{em}$ 1986, estudaram a precisão de medidas oriundas de radiografias tomadas subseqüentemente e concluíram que as radiografias interproximais obtidas de uma mesma região repetidas vezes, sem a utilização de posicionadores radiográficos individuais, possuem alta precisão quanto à confiabilidade de medidas.

JEAN et al ${ }^{30}$, em 1996, avaliaram um método para quantificar mudanças no osso alveolar através da técnica de subtração de imagem. As radiografias periapicais foram padronizadas através do uso de posicionadores Rinn XCP® (Dentsply) e individualizações através de registros oclusais realizados com um material de moldagem (Impregum®). Os autores conseguiram quantificar a variação de quantidade óssea nos sitos periodontais e concluíram que o método é eficiente.

CARPIO et al' ${ }^{12}$, em 1994, afirmam que blocos de mordida feitos em acrílico, moldando a superfície dos dentes da região de interesse, não sofrem o inconveniente da distorção do material, quando adequadamente armazenados, como acontece com a maioria dos blocos obtidos de outros materiais de moldagem.

Outro ponto importante referente à avaliação radiográfica do periodonto é a determinação da crista óssea alveolar, uma vez que sua posição radiográfica sofre bastante influência da angulação vertical do feixe de raios X durante a exposição (HAUSMAN et al ${ }^{25}$, 1989). Para facilitar a reprodutibilidade da crista óssea alveolar entre radiografias, ela é definida como a projeção radiopaca mais coronal da crista ${ }^{25}$.

Em diversos trabalhos, a crista óssea alveolar é relacionada com a junção amelo-cementária. Por esta razão, HAUSMANN et al ${ }^{26}$, ainda em 1989, descreveram uma série de regras para definir exatamente esses 
dois reparos em radiografias interproximais, levando em consideração algumas variações anatômicas. Assim, os autores classificaram os reparos em ideais e não-ideais, da seguinte maneira: (1) junção amelocementária ideal: extensão mais apical do esmalte, que pode ser identificada como uma alteração de densidade referente à interface entre esmalte e superfície radicular, ou como o local de mudança no contorno dentário entre a coroa e raiz, ao longo da face interproximal do dente; (2) junção amelo-cementária não-ideal: caso a interface onde ocorre a alteração de densidade não coincida com o ponto de mudança no contorno dentário, a junção deve ser marcada no ponto de alteração de densidade; se apenas uma das duas referências citadas mostrar-se visível, esta deverá ser marcada como a junção; e, finalmente, se ambas as referências não forem detectáveis, a radiografia deve ser desprezada para fins de obtenção de medidas que envolvam a junção amelocementária.

As regras para marcação da crista óssea alveolar também foram descritas no mesmo trabalho: (1) crista óssea alveolar ideal: o ponto interproximal mais coronal claramente definido como uma mudança de densidade imediatamente adjacente à raiz; (2) crista óssea alveolar nãoideal: em alguns casos, pode-se perceber que o ponto acima citado situase coronalmente à junção amelo-cementária; nesses casos, despreza-se essa medida, ou se considera a crista como sendo o ponto de densidade óssea mais coronal, apicalmente à junção; em certos casos, principalmente em defeitos ósseos verticais, o osso alveolar parece inclinar-se a partir da raiz, afastando-se dela, então, a crista deve ser marcada como sendo o ponto a partir do qual o osso alveolar começa a afastar-se da superfície dentária. 
Apesar de alguns inconvenientes da técnica radiográfica convencional, tais como o processamento e armazenamento, deve-se convir que os filmes mostram-se como um método acessivel e bem aceito de se arquivar imagens obtidas. Por esse fator, talvez as alternativas introduzidas dos filmes intrabucais, como a xerorradiografia, a cintilografia e a radiografia por subtração tenham sido, na maioria das vezes, desprezadas ou pouco utilizadas. (CLASEN \& AUN ${ }^{13}, 1998$ )

Hoje a mais recente opção em radiografias intrabucais é a radiografia digital direta (RDD), bem recebida em diversas áreas da Odontologia, por propiciarem imagens instantâneas que requerem menor tempo de exposição, dispensando o processamento químico necessário nos filmes periapicais. Estas características conferem rapidez e possibilidade de se obterem múltiplas imagens radiográficas de modo a diminuir o tempo de exposição e operatório, utilizando-se para tal um sensor intrabucal em substituição à película radiográfica ${ }^{13}$.

A Soredex Orion Corporation ${ }^{63}$ (Heilsinki, Finlândia) lançou o Digora ${ }^{\circ}$, um sistema de radiografia digital. Nesse sistema o feixe de raios X incide sobre uma placa óptica intrabucal, constituída por partículas de fósforo, que convertem os raios X em luz visível, formando uma imagem latente. Essa placa, após a exposição, é levada ao aparelho Digoraß, sendo processada com o auxilio de um scanner, onde é atingida por um feixe de laser, ocasionando a emissão de luz. A luz então é captada por um fotodetector e transformada em sinais elétricos que serão enviados ao software responsável pelo processamento da imagem digital. Existem dois tamanhos de placas, 35X26 mm e 45X35 mm, ambas com espessura de 1,4mm, a mesma de filmes radiográficos convencionais. (CLASEN \& AUN ${ }^{13}, 1998$, WENZEL \& GRÖNDAHL $\left.{ }^{76}, 1995\right)$. Dentre as 
principais vantagens descritas, cumpre ressaltar que há redução da dose de radiação, que chega a ser de 60 a 90\% menor, dependendo do tipo de aparelho, significando uma queda do tempo de exposição de 0,4 segundos, para 0,12 ou 0,20 segundos (CLAUSEN \& AUN 1998), ou 20\% da dose de um filme convencional com sensibilidade $D^{76}$.

Outra vantagem é que as radiografias são praticamente instantâneas, não necessitando de processo químico, o que reduz o tempo operatório ${ }^{13}$.

Há também possibilidade do tratamento eletrônico da imagem, que pode ser trabalhada quanto ao brilho, contraste, inversão (positivonegativo), relevo, rotação, colorido. Há também o recurso de zoom, que permite visualização de detalhes e pode ser associado aos outros tratamentos eletrônicos. (CLASEN \& AUN'13, 1998, LAURIS, COSTA \& BÓsCOLO ${ }^{40}, 2001$, VERSTEEG et $\mathrm{al}^{74}$, 1998/As medidas lineares $\mathrm{e}$ angulares podem ser obtidas de maneira rápida e precisa, sendo calculados pelo software.

Há também a possibilidade de obtenção da densidade da imagem, para observar rarefações ósseas, reabsorções ou implantes, entre outros. Essa densidade pode ser obtida em um ponto, linha ou área. A densidade ao longo dessa área será representada em um gráfico. Podese fazer a comparação simultaneamente na tela, entre duas ou mais tomadas radiográficas realizadas em datas diferentes, recurso de fundamental importância na proservação de lesões periapicais e controles pós-operatórios. No entanto, tais tomadas devem ser feitas com rigorosa precisão do tempo de exposição e angulações horizontal e vertical, já que a menor alteração em uma dessas variáveis resultará em diferentes contrastes de imagens, invalidando as comparações. Os tons 
de cinza da imagem que possuem a mesma densidade aparecem na mesma tonalidade, o que é evidenciado pelo histograma representativo da distribuição dos níveis de cinza (LAURIS, COSTA \& BÓSCOLO ${ }^{40}, 2001$ ). A avaliação prospectiva da densidade óssea em um local em reparo permite detectar a quantidade de minerais que foi ganho ao longo do tempo, podendo ser um método de avaliação da evolução do reparo. I CLASEN \& AUN $\left.{ }^{13}, 1998\right)$

A introdução da tecnologia da imagem digital no diagnóstico Odontológico ofereceu um método mais sensível que a analise radiográfica convencional. A detecção de sutis mudanças na densidade do osso alveolar, indicadora de perdas e ganhos teciduais do periodonto teve sua visualização facilitada pela subtração digitalizada, pelas radiografias padronizadas, quando comparadas às interpretações subjetivas da radiografia convencional. A radiografia digital mostra uma modificação na imagem, isto é, margem e contraste podem ser realçados, melhorando o nível de concordância inter e intraobservadores, na estimativa de mudanças de densidade do osso. (TAVANO et al ${ }^{69}, 1999$ )

TAVANO et al ${ }^{69}$, em 1999, em um estudo comparando a análise subjetiva (com scores de 0 a 10) da densidade óssea após implantes de polímero de mamona em radio de coelhos, com a análise digital, com valores de 0 (preto) a 255 (branco) e concluíram que as imagens digitais obtidas pelo sistema Digora® oferecem melhores condições de visualização, objetividade e precisão para realização da interpretação radiográfica da evolução do reparo ósseo, tanto nos grupos controle (coágulo) como experimental (enxerto). 
KHOCHT et al ${ }^{32}$, em 2003, compararam a eficiência em detectar perda óssea periodontal, comprando radiografias periapicais convencionais e digitais diretas. Através da realização de medidas entre a crista óssea alveolar e a junção amelo-cementária, com uma régua transparente para as convencionais e com o uso de medidas do software nas digitais, os autores concluíram que houve diferenças entre os resultados obtidos pelas duas técnicas, sendo que a digital tende a revelar um maior número de sítios com recém ou moderada perda óssea comparada ̀̀ radiografia convencional.

Outra vantagem é a possibilidade de armazenamento das imagens em disquetes, CDs ou em disco rígido, permitindo sua reprodução, bem como impressão das mesmas (CLASEN \& AUN'13, 1998). Todos os dados do paciente podem ficar armazenados em um mesmo arquivo, sendo facilmente acessado. (WENZEL \& GRÖNDAHL $\left.{ }^{76}, 1995\right)$. 
3 - Proposição 


\section{$\underline{\text { PROPOSICÃO }}$}

Frente ao que foi apresentado na Revisão de Literatura, a proposta do presente estudo foi comparar a eficácia de enxertos de Gen-tech®, associado à membrana Gen-Derm®, em relação ao preenchimento por coágulo de alvéolos de terceiros molares inferiores não-irrompidos através de medidas da distância da crista óssea alveolar à junção amelocementária, avaliando a condição periodontal radiográfica, e medidas da densidade óssea. 


\section{4-Material e Métodos}




\section{MATERIAL E MÉTODOS}

\section{1 - Amostra}

A amostra do presente trabalho foi constituída de 39 pacientes selecionados dentre os que procuram tratamento na Disciplina de Cirurgia, do Departamento de Estomatologia, da Faculdade de Odontologia de Bauru - Universidade de São Paulo, obedecendo aos seguintes critérios:

- Pacientes de até 25 anos de idade, sem distinção de gênero ou raça;

- Pacientes com radiografia panorâmica recente (de até seis meses) e de boa qualidade, na qual se observa a presença de terceiros molares inferiores não-irrompidos, bilateralmente, de posição simétrica quanto às classificações de WINTER ${ }^{78}$ (angulação) e PELL \& GREGORY51 (relação com o longo eixo do segundo molar adjacente e com o ramo ascendente da mandíbula);

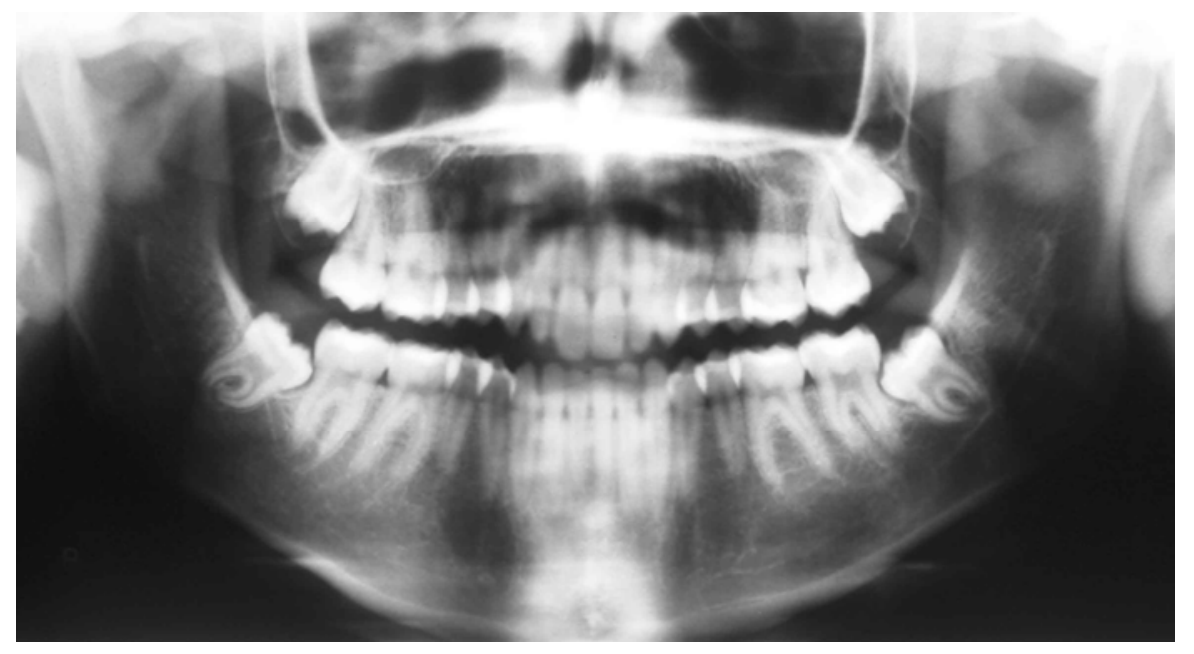

Figura 4. 1- Radiografia panorâmica selecionada 
- Pacientes que apresentavam os segundos molares inferiores integros e bem posicionados;

- Pacientes que apresentavam bom estado de saúde geral, sem quaisquer alterações locais ou sistêmicas, clínicas ou radiográficas, que pudessem interferir no reparo pós-operatório;

- Pacientes não gestantes;

- Pacientes não-fumantes;

-Pacientes que assinassem o Termo de Consentimento Livre e Esclarecido (anexo A) para participar da pesquisa, após lerem a Carta da Informação ao paciente (anexo B).

\section{2 - Seleção da amostra}

Inicialmente, houve uma pré-seleção dos pacientes através das radiografias panorâmicas, seguindo-se os critérios radiográficos citados.

Após essa pré-seleção, os pacientes foram agendados para uma primeira consulta quando se realizou anamnese, exame físico e exame clínico, com o intuito de confirmar se o paciente enquadrava-se nos critérios de seleção estabelecidos.

Os pacientes que não se enquadraram nos critérios de seleção ou que não concordaram em participar da pesquisa foram encaminhados às clínicas regulares da Disciplina de Cirurgia.

Nessa primeira consulta, o paciente era informado sobre a pesquisa e, após a leitura da Carta de Informação ao Paciente (anexo B), assinava o Termo de Consentimento Livre e Esclarecido (anexo A), entrando, então, para a amostra da pesquisa. 
Ainda nessa consultas, eram tomados os registros oclusais nos posicionadores radiográficos individuais, conforme descrito adiante, e agendada a primeira cirurgia.

\section{3 - Divisão da amostra em grupos}

Os 40 pacientes tiveram seus terceiros molares inferiores divididos em dois grupos, controle e experimental, de modo que cada paciente tinha um dente no grupo controle e outro no grupo experimental.

\subsection{1 - Grupo controle}

Para o grupo controle, foi realizada a exodontia do terceiro molar inferior, seguida de curetagem do folículo pericoronário, irrigação com soro fisiológico e sutura. Foi realizada uma radiografia digital direta do pós-operatório imediato.

\subsection{2 - Grupo experimental}

No grupo experimental, após a exodontia, curetagem de folículo pericoronário e irrigação abundante com soro fisiológico, foi realizada uma radiografia digital direta do trans-operatório. O material de enxerto foi hidratado com soro fisiológico e aplicado no alvéolo, seguido de posicionamento da membrana e sutura. Foi também realizada a radiografia digital direta do pós-operatório imediato.

As extrações eram iniciadas de um lado escolhido aleatoriamente para que a amostra ficasse randomizada. 
Os pacientes que apresentavam terceiros molares superiores com indicação para extração tinham tais dentes extraídos na mesma sessão do antagonista do mesmo lado. Rotineiramente, foi proposto aos pacientes a realização das exodontias em duas cirurgias: primeiro, um lado (superior e inferior), depois, o outro. Em alguns casos, por opção dos pacientes, foi realizada a exodontia de todos os terceiros molares na mesma sessão.

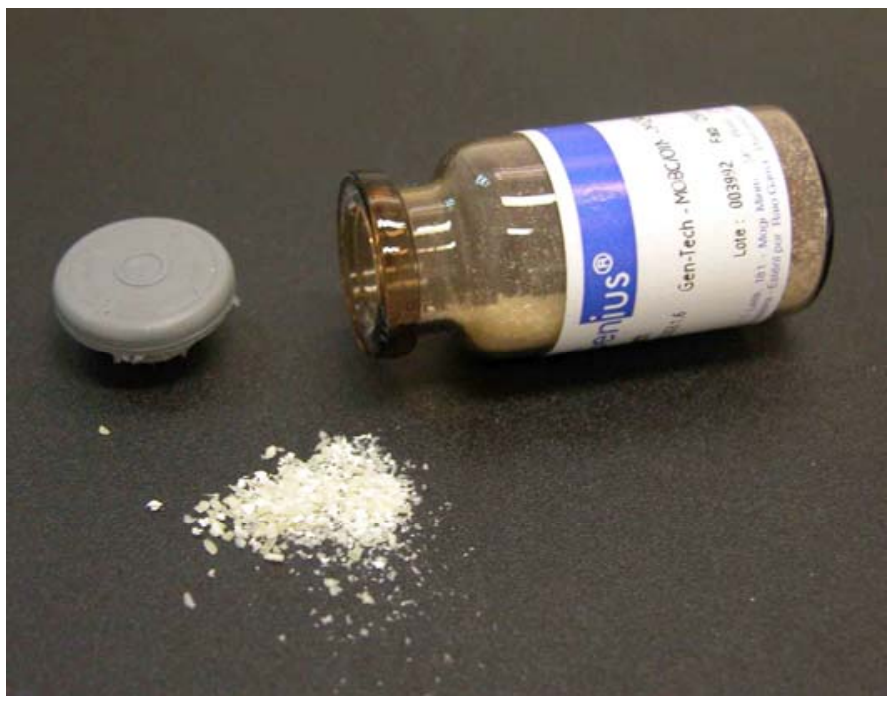

Figura 4.2 - Material utilizado - Osso bovino orgânico + inorgânico + Colágeno + BMP (Gen-tech®)

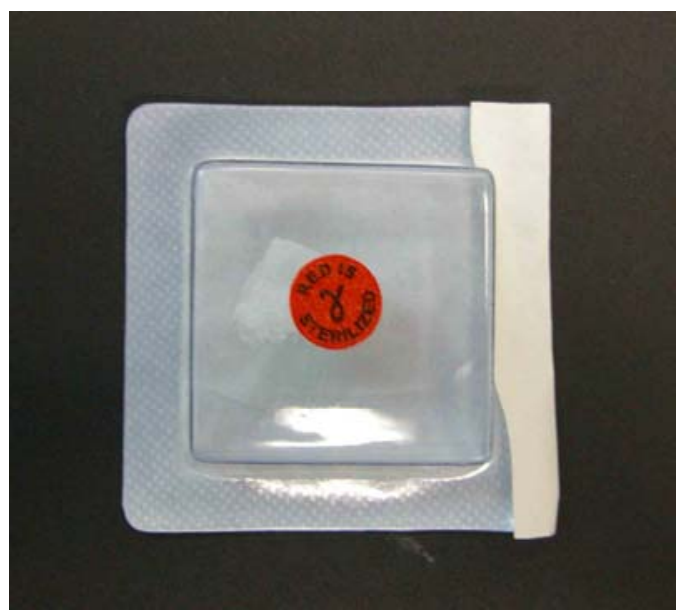

Figura 4.3 - Material utilizado - Membrana de cortical óssea bovina liofilizada (Gen-Derm®) 


\section{4 - Confecção dos posicionadores radiográficos}

Os posicionadores radiográficos que foram utilizados neste estudo foram desenvolvidos seguindo-se a metodologia descrita por TABA JÚNIOR ${ }^{64}$ em 1995, a fim de se obter imagens radiográficas padronizadas.

Inicialmente, durante a fase de desenvolvimento do posicionador, foi confeccionado manualmente um bloco de mordida matriz em acrílico, obedecendo aos seguintes critérios:

- Permitir o posicionamento do sensor radiográfico paralelo ao dente;

- Facilidade de duplicação;

- Fidelidade na padronização;

- Durabilidade para tomadas radiográficas seqüenciais;

- Extensão suficiente para se obterem imagens de praticamente todo alvéolo

A partir do bloco de mordida matriz, foi confeccionado um molde de silicone industrial para a duplicação dos blocos de mordida em acrílico. $\bigcirc$ material acrílico utilizado foi o Resapol T208 à base de poliéter e catalisador peroxol com acelerador de cobalto.
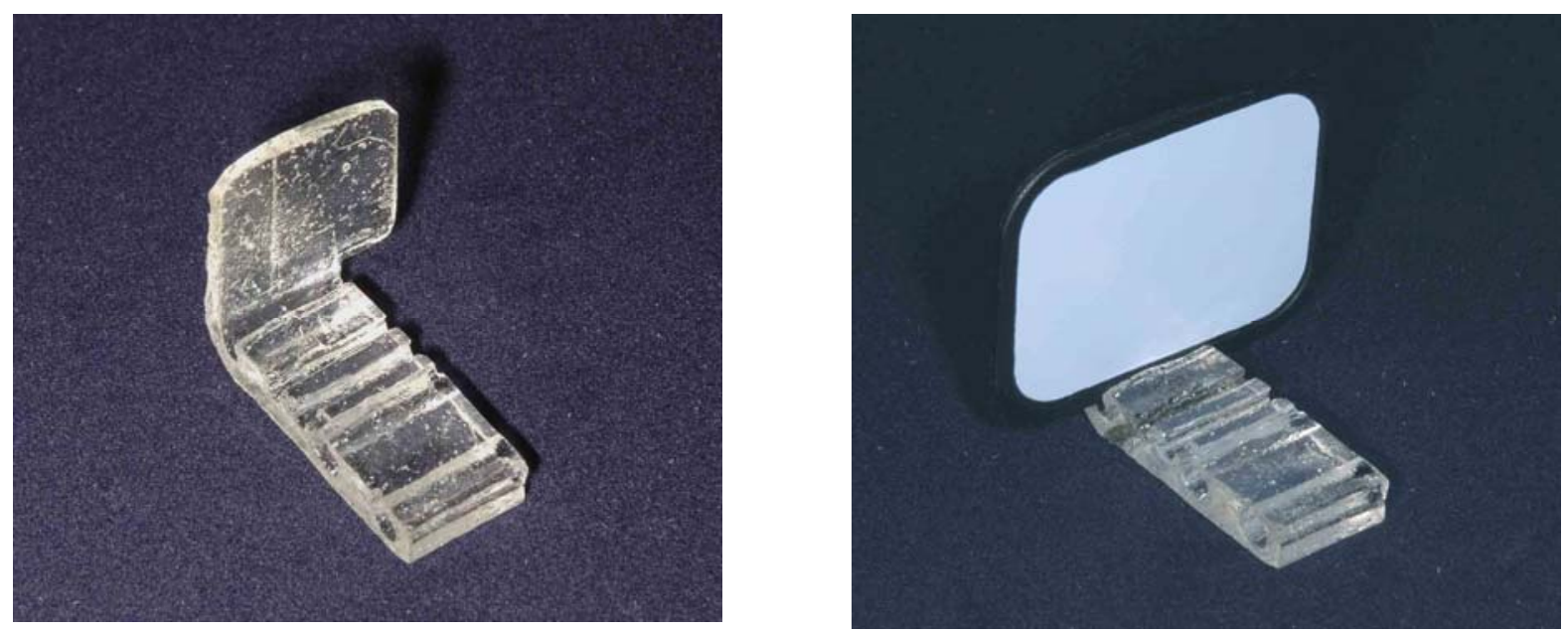

Figura 4.4 - Bloco de mordida e Figura 4.5 - Sensor adaptado ao bloco de mordida em acrílico. 
Os blocos de mordida possuíam encaixes para a adaptação dos posicionadores para radiografias periapicais pela técnica do cilindro Iongo (Posicionador RINN XCP, Dentsply), que têm um anel localizador acoplado para o posicionamento do aparelho de raios $X$.
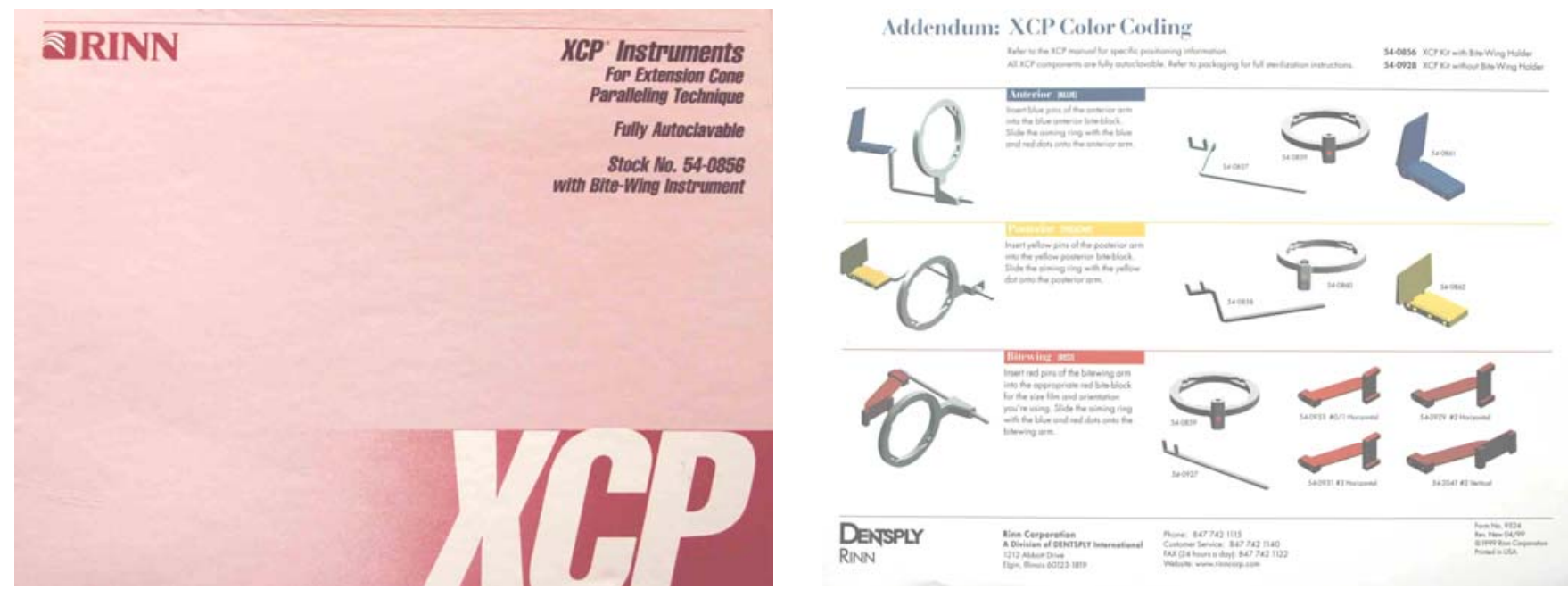

Figura 4.6 - Embalagem dos posicionadores RINN - XCP e Figura 4.7 - Os tipos de posicionadores e suas aplicações.
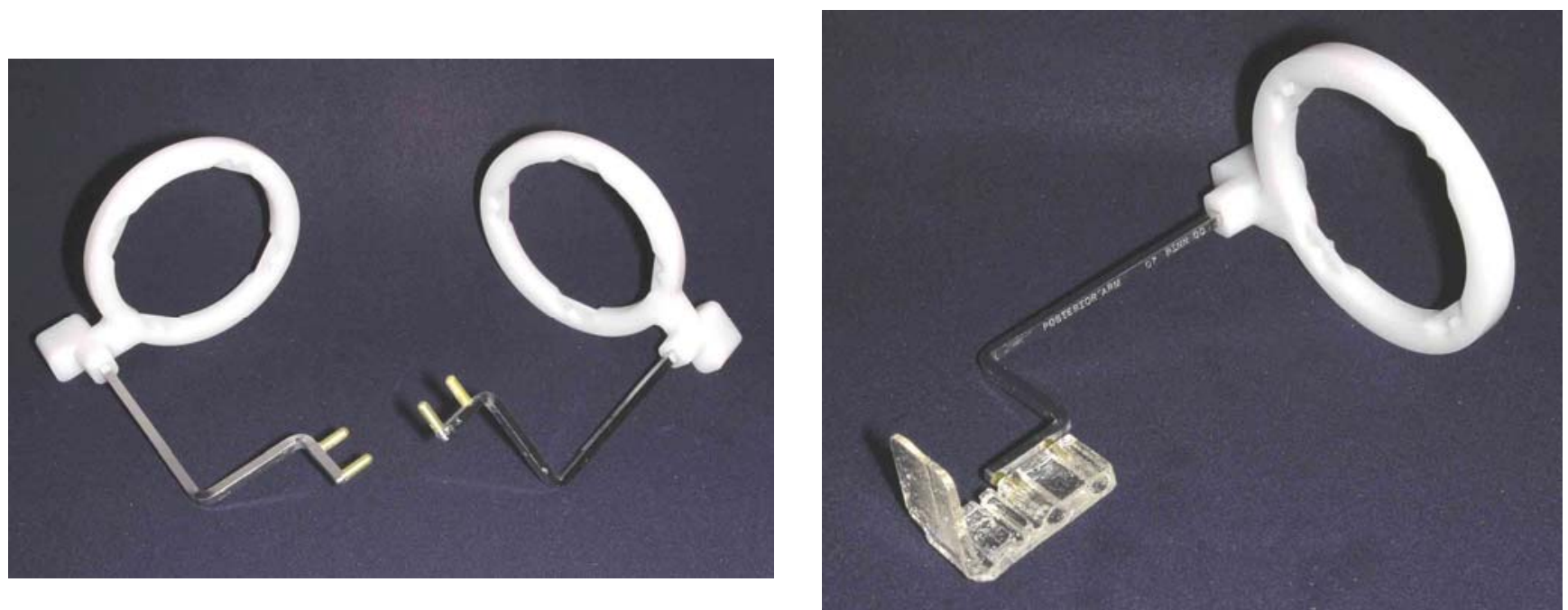

Figura 4.8 - Posicionador RINN-XCP para pré-molares e molares e Figura 4.9 - Posicionador com o bloco de mordida adaptado 


\section{5- Individualização dos posicionadores radiográficos}

A padronização das imagens foi conseguida através de um registro oclusal, da região de primeiros e segundos molares, confeccionado em resina Duralay em cada posicionador, específico para cada lado a ser radiografado, de modo que cada paciente tinha dois posicionadores (lados direito e esquerdo).

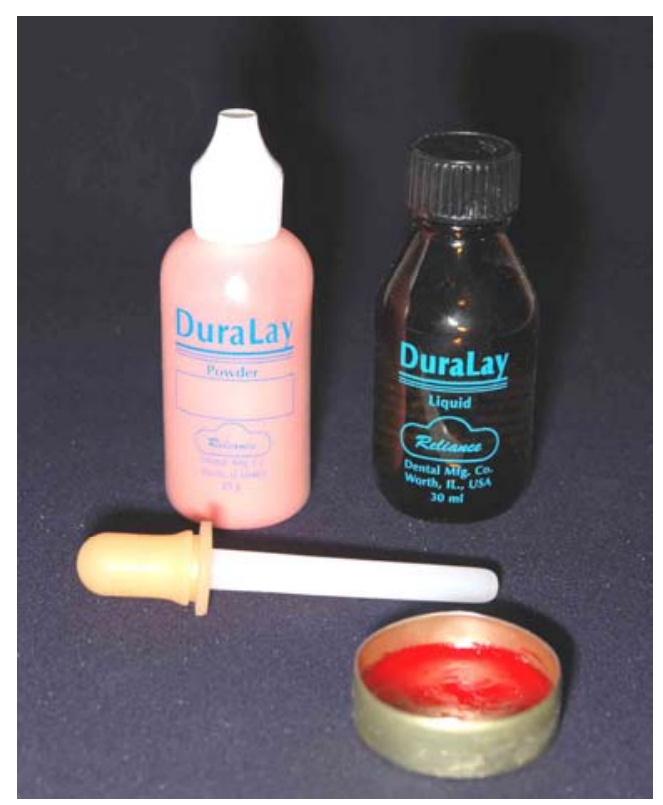

Figura 4.10 - Resina Duralay

Os pares de blocos de mordida de cada paciente foram armazenados em embalagens plásticas identificadas pelo nome do paciente durante toda a pesquisa e imersos em água, para evitar a distorção da resina. Os posicionadores do lado direito foram diferenciados através de uma marcação com etiqueta. Os excessos de resina Duralay foram removidos com uma broca Maxicut para peça de mão.

Antes da tomada do registro oclusal, os dentes envolvidos foram Iubrificados com vaselina (do próprio conjunto da resina Duralay) e, 
durante a polimerização da resina, os dentes eram refrigerados com spray de água através da seringa tríplice.
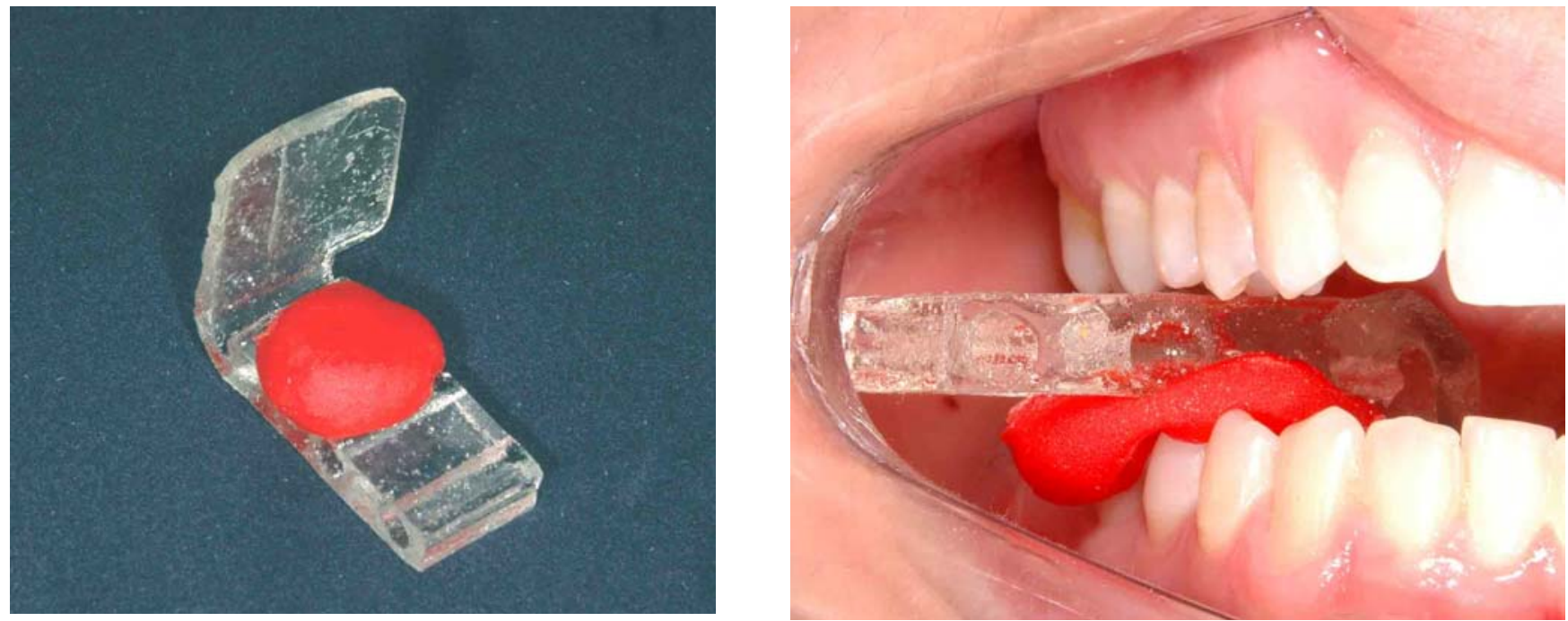

Figura 4.11- Bloco de mordida com resina Duralay e Figura 4.12- Obtenção do registro oclusal.

Os registros oclusais foram obtidos em sessão prévia à cirurgia, com o intuito de se garantir a completa polimerização do material, evitando-se distorções nas tomadas subseqüentes.

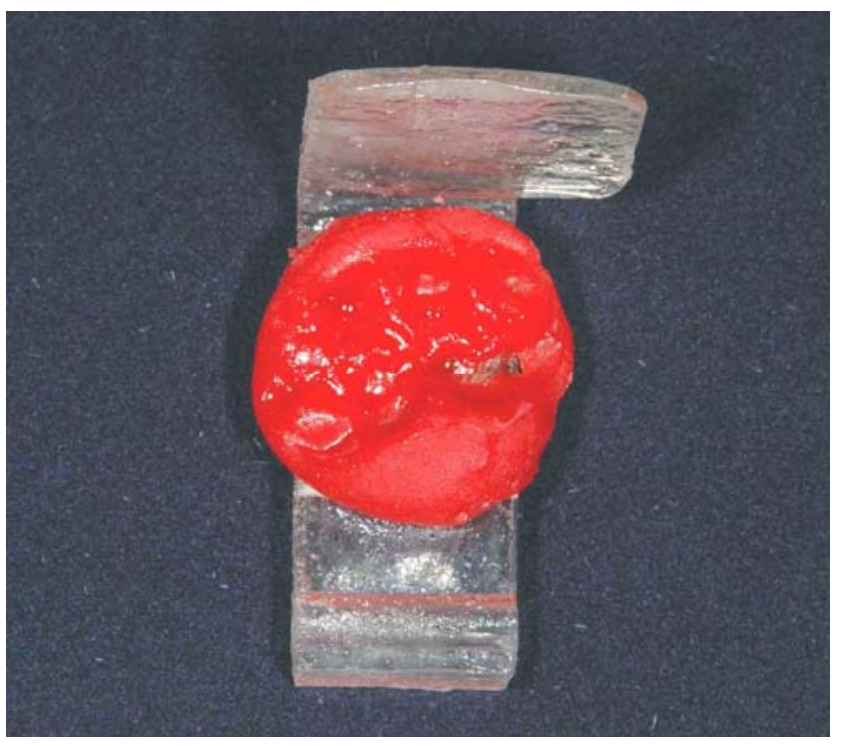

Figura 4.13 - Registro oclusal 


\section{6- Técnica cirúrgica}

As cirurgias para a exodontia dos terceiros molares foram realizadas segundo preconiza a Disciplina de Cirurgia, da Faculdade de Odontologia de Bauru, da Universidade de São Paulo, estando de acordo com todas as normas estabelecidas pela Comissão de Biossegurança da referida instituição.

Todas as cirurgias e demais consultas pré e pós-operatórias foram realizadas nas dependências da Clínica de Cirurgia e da Clínica de Estomatologia da Faculdade de Odontologia de Bauru, da Universidade de São Paulo.

\subsection{1 - Anti-sepsia}

A anti-sepsia interna foi realizada através de bochechos com Listerine ${ }^{\circledR}$ durante 30 segundos, conforme recomendado pelo fabricante do produto. A anti-sepsia externa foi obtida com o uso de um agente à base de clorexidina (Periogard®) sobre a face do paciente, imediatamente antes da colocação do campo fenestrado.

\subsection{2 - Anestesia}

Foi realizado o bloqueio do nervo alveolar inferior através da técnica direta, com agulha curta. O anestésico de escolha foi a mepivacaína, Scandicaine 2\% especial com noradrenalina® (Septodont). Após o bloqueio do nervo alveolar inferior, procedeu-se anestesia infiltrativa na área a ser manipulada, visando uma melhor hemostasia e facilitando o rebatimento do retalho.

\subsection{3 - Incisão e rebatimento do retalho}


Para todos os casos, foi realizada incisão intrasulcular, sem incisão vertical (relaxante) para obtenção de um retalho total em envelope. A incisão, realizada com lâmina no 15, se iniciou sobre o ramo ascendente da mandíbula, cerca de 1 a 2 centímetros de distância do segundo molar, até tocar a sua face distal. A incisão estendeu-se por via intrasulcular, contornando a face vestibular do segundo molar até envolver a papila interdental entre o primeiro e o segundo molares.

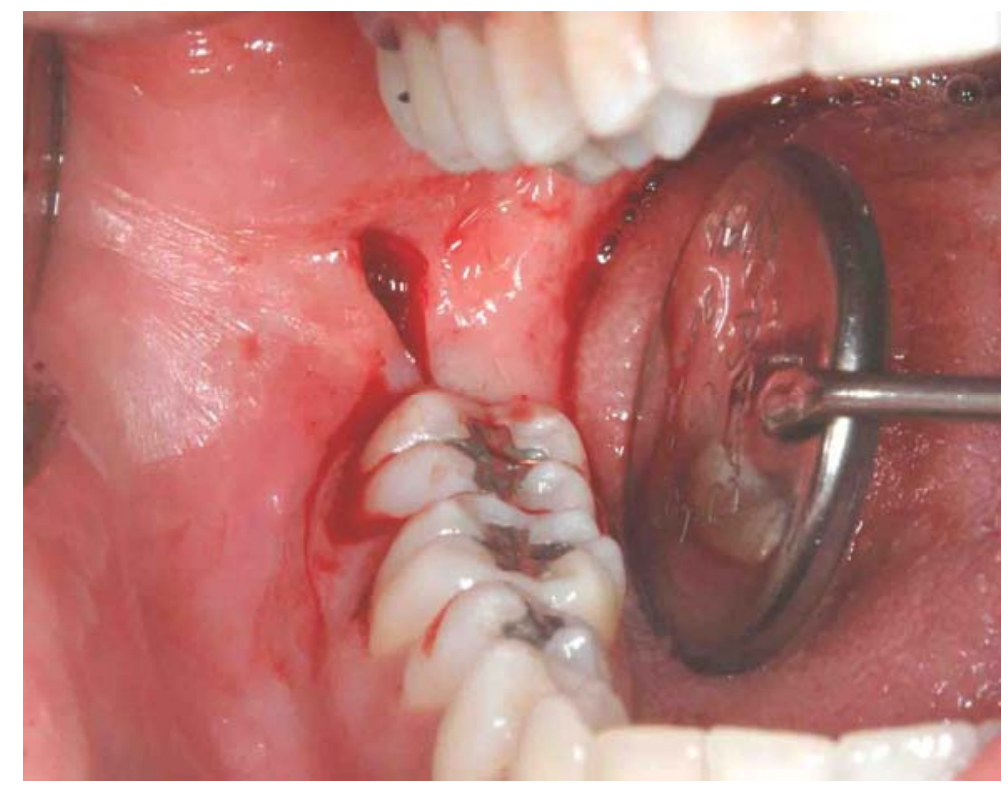

Figura 4.14 - Incisão

O rebatimento do retalho total (muco-periostal) foi realizado com descolador de Molt no 3, expondo-se toda a tábua óssea vestibular ao terceiro molar não-irrompido, até que todas as fibras e periósteo fossem rebatidos. 


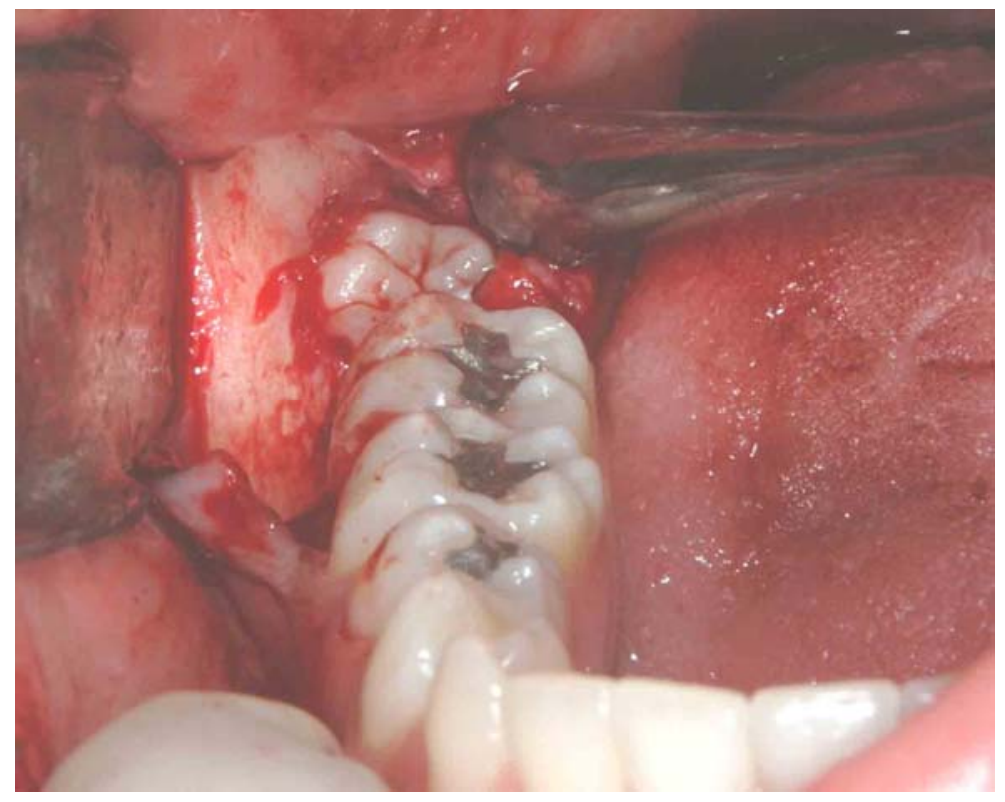

Figura 4.15 - Retalho rebatido

\subsection{4 - Osteotomia}

A osteotomia, quando necessária, era realizada com broca carbide no 6, esférica, em alta rotação, sob refrigeração, até que todo o equador protético do dente não-irrompido fosse exposto, por vestibular e distal, liberando-o. Como se tratava de pacientes portadores de terceiros molares não-irrompidos simétricos, a ostectomia, quando necessária para um lado, também o era para o outro, evitando, assim, possíveis alterações durante o reparo. 


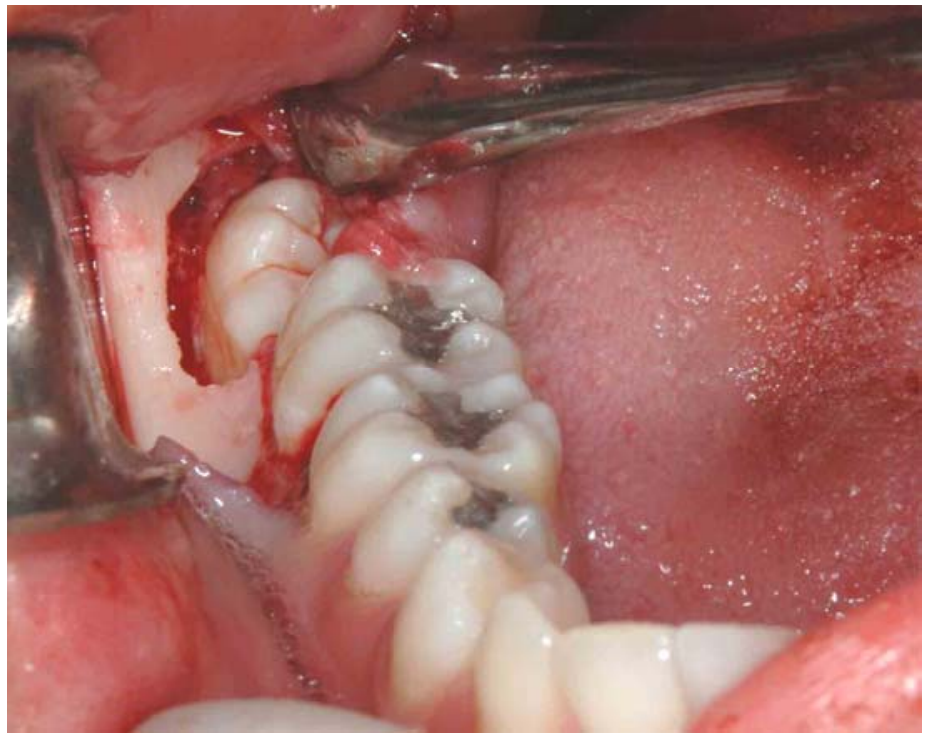

Figura 4.16.- Osteotomia realizada

\subsection{5 - Odontossecção}

Nos casos onde foi necessário o seccionamento dos terceiros molares, este foi realizado com broca diamantada no 4138 (troncocônica) em alta rotação, sob refrigeração, com o intuito de eliminar as impacções da coroa ou separar as raízes quando, divergentes ou dilaceradas. Durante todo o tempo de utilização da caneta de alta rotação, seja para osteotomia ou odontossecção, um descolador de Freer foi colocado em posição para proteger o nervo lingual.

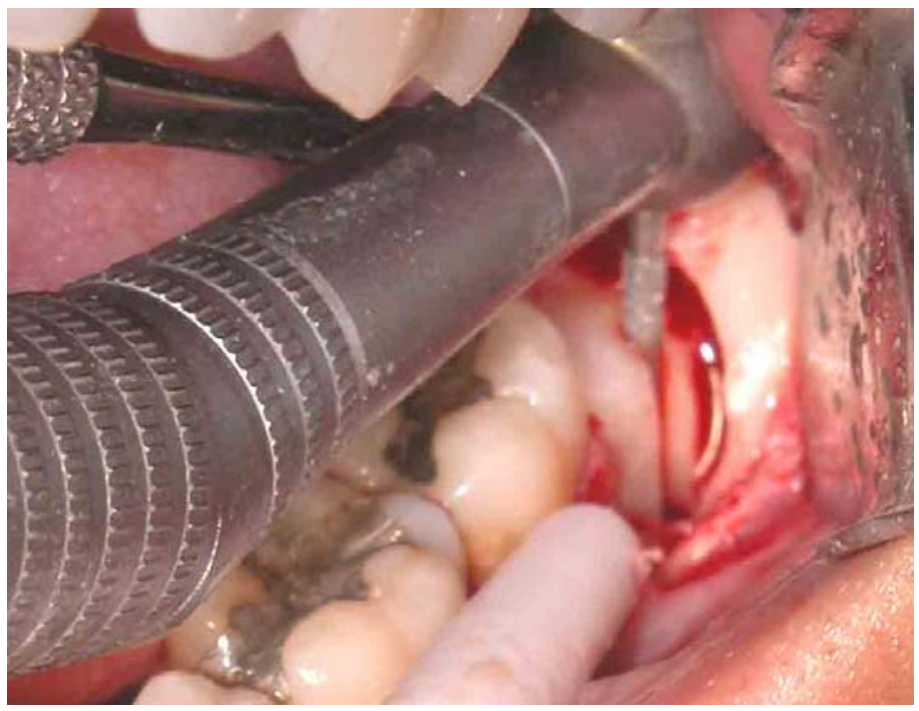

Figura 4.17 - Odontossecção sendo realizada 


\subsection{6 - Exodontia}

Após a realização da osteotomia e odontossecção, quando necessário, o dente foi então extraído, inteiro ou em partes, conforme o planejamento. Para tal procedimento, fez-se uso de extratores com movimentos de cunha, sarilho e alavanca.

\subsection{7 - Cuidados pós-exodontia}

Após a exodontia, foi realizada a remoção do folículo pericoronário, a inspeção das corticais ósseas e a limagem do osso alveolar para remoção de possíveis espículas e irrigação abundante com soro fisiológico.

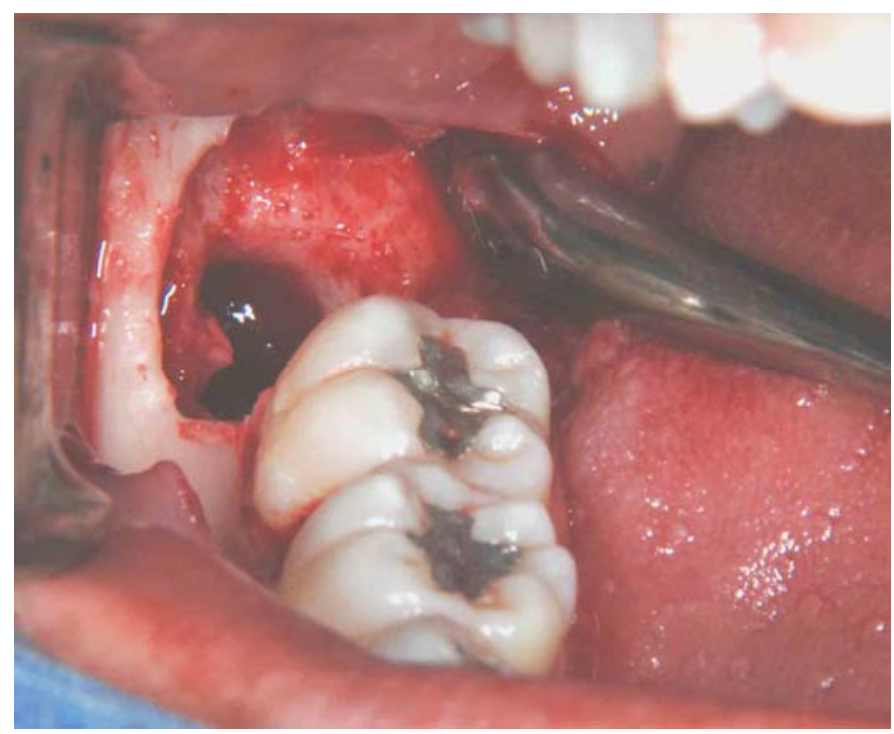

Figura 4.18 - Alvéolo após a exodontia

O grupo experimental teve mais uma etapa, onde foi aplicado o biomaterial proposto, hidratado em pote Dappen com soro fisiológico, utilizando cureta de Lucas, compactando-o com o auxilio de gaze umedecida, preenchendo todo o alvéolo. 

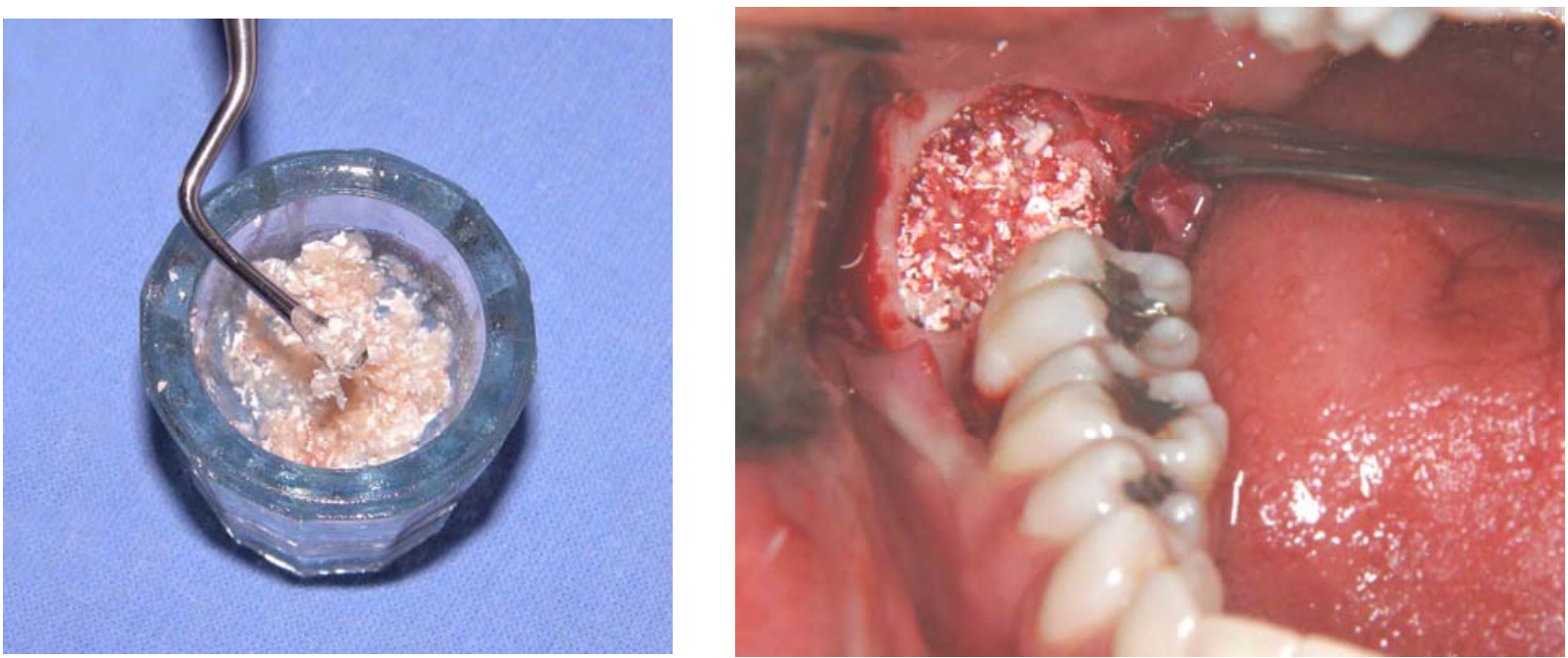

Figura 4.19 - Material (Gen-Tech) preparado para ser aplicado e Figura 4.20 - Alvéolo com Gen-tech ${ }^{\circledR}$

Após o preenchimento foi posicionada a membrana já hidratada e recortada de acordo com o desenho da área, cobrindo todo o alvéolo e posicionada junto ao retalho vestibular e lingual que foram reposicionados no local de origem.

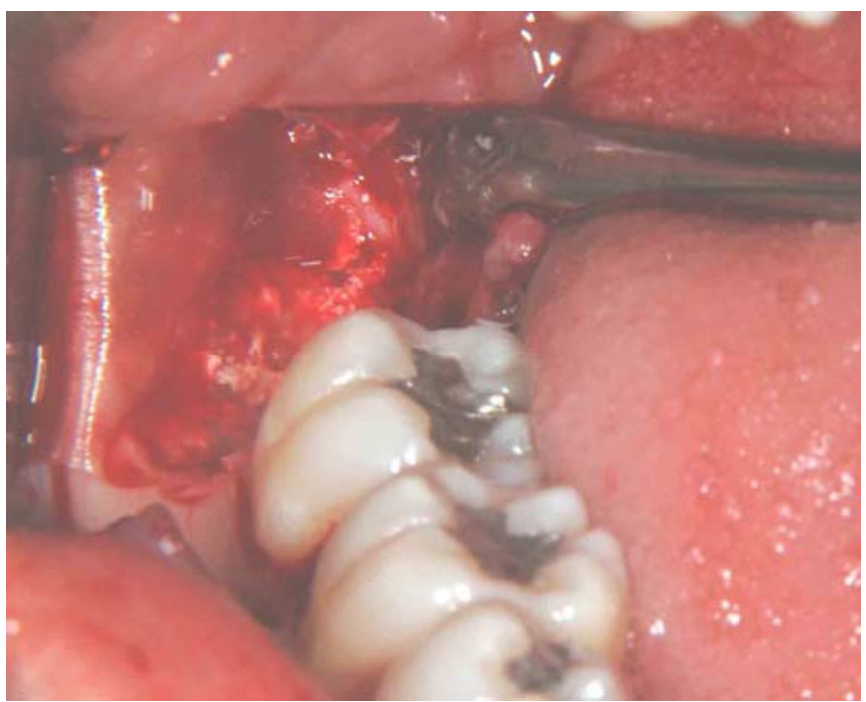

Figura 4.21 - Membrana posicionada 


\subsection{8 - Sutura}

A sutura foi realizada com fio de seda 4-0, sendo iniciada na papila entre o primeiro e o segundo molar, de modo a passar por baixo do ponto de contato, ancorando a papila vestibular à mucosa lingual.

O segundo ponto, simples, foi dado na distal do segundo molar, no sentido de se atenuar a deiscência pós-operatória. Por fim, suturou-se a porção distal do retalho, sobre o ramo ascendente da mandíbula. Era importante que a sutura fosse muito bem feita para não expor a membrana no grupo experimental.

A sutura foi removida, preferencialmente, no quinto dia de pósoperatório, ou no sétimo dia de pós-operatório.

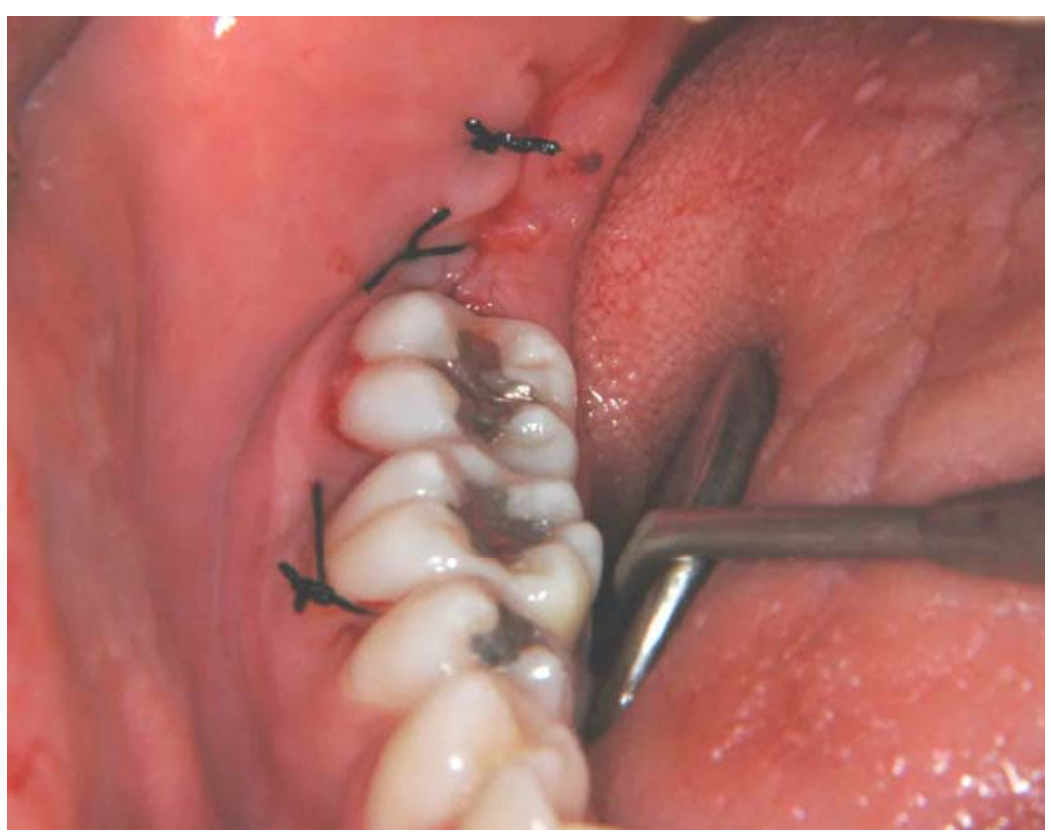

Figura 4.22 - Sutura 


\subsection{9 - Cuidados pós-operatórios}

Os pacientes receberam verbalmente e por escrito as orientações gerais de rotina para o pós-operatório de cirurgia de dentes nãoirrompidos, bem como orientações quanto à higienização. Para todos os casos foram prescritos antibióticos, antiinflamatórios e analgésicos quando necessários.

\section{7 - Critérios de avaliação}

Foram realizadas análises ao longo do tempo inter e intragrupos dos seguintes critérios: distância da crista óssea alveolar à junção amelocementária na distal dos segundo molares e a densidade óssea no alvéolo de ambos os lados.

4.7.1 - Distância da crista óssea alveolar à junção amelocementária

Os dados foram obtidos por meio de tomadas radiográficas periapicais digitais pelo sistema Digora® /Soredex Orion Corporation referência) utilizando um aparelho de raios X Yoshida Kaycor X-707 operando com 70 KVp e 7 mA e tempo de exposição de 0,20 segundos.

○ Digora® é um sistema de radiografia digital direta. Segundo o fabricante, trata-se de um sistema digital de scaneamento, tratamento e arquivamento de imagens radiográficas digitais. As imagens são capturadas numa placa ótica de fósforo, ao invés de num filme 
radiográfico convencional, e as imagens obtidas possuem as mesmas medidas das de um filme convencional.

Este sistema diminui o tempo de exposição requerido para obtenção de imagens radiográficas / de 20 a 50\% das doses requeridas pelos filmes rápidos), daí ter sido utilizado apenas 0,20 segundo.

As radiografias foram padronizadas através da utilização de posicionadores radiográficos individuais nas tomadas radiográficas seqüenciais.

Os sensores de fósforo do Digora® foram envoltos por uma capa plástica do próprio sistema, para proteção do sensor contra luz após a exposição aos raios X e contra o contato com a saliva do paciente. Para assegurar maior proteção contra contaminação por sangue e saliva, já que haviam radiografias realizadas no trans-operatório, além da capa plástica do sistema, o sensor foi envolto em um filme de PVC. Também foram realizadas desinfecções dos posicionadores a cada tomada radiográfica.

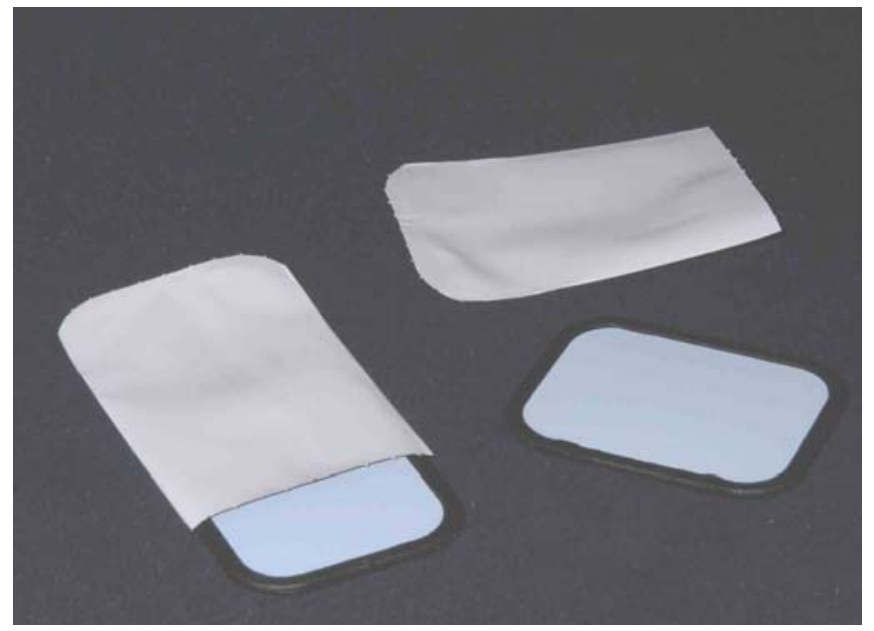

Figura 4.23 - Sensores do Digora® e capa plástica protetora 
Após a exposição do sensor, este foi inserido no scanner do aparelho para leitura e geração da imagem na tela do computador.

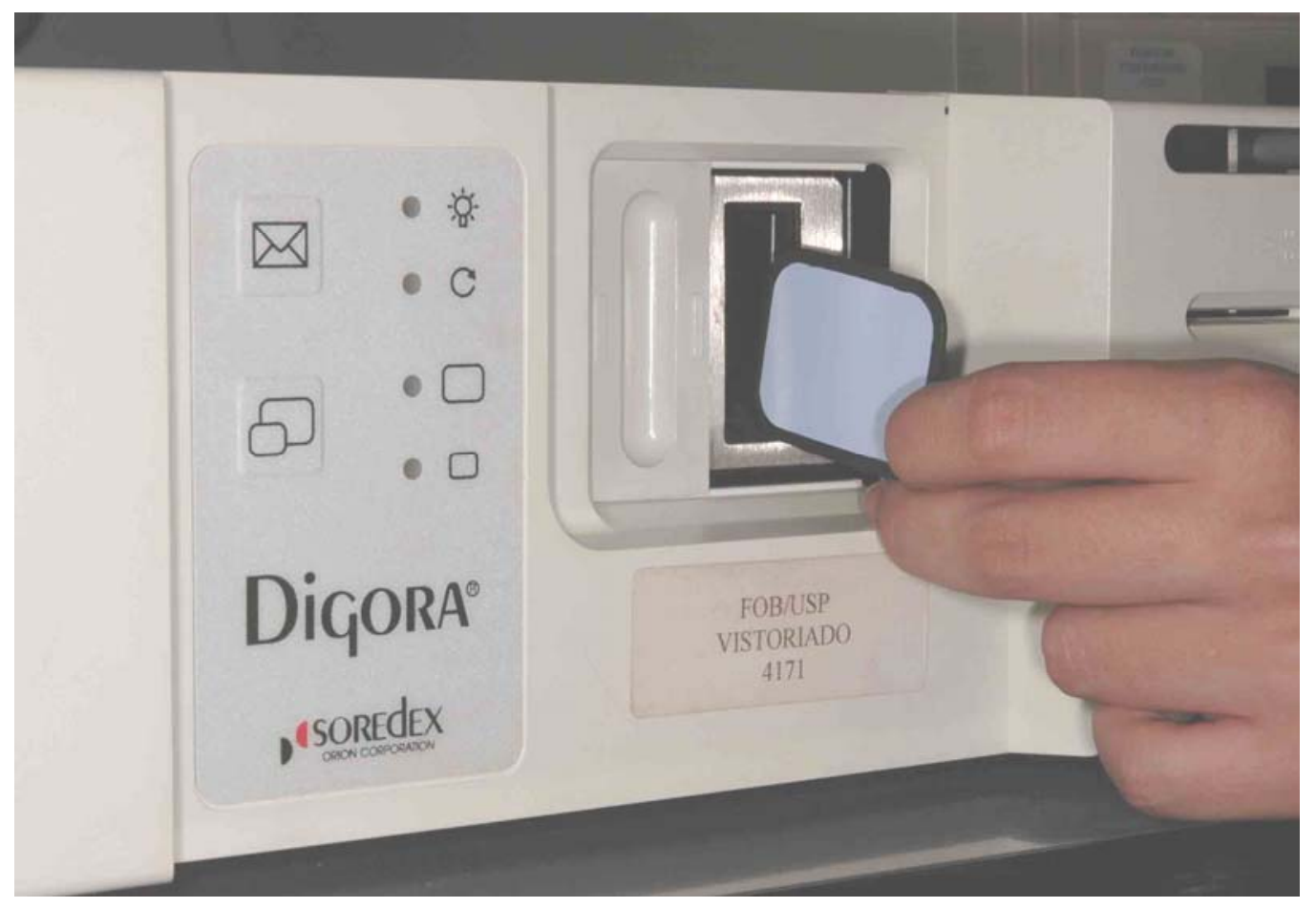

Figura 4.24 - Scanner do Digora®

Com a imagem radiográfica no monitor do computador, tornou-se possível a manipulação dessa imagem, alterando-se o brilho e o contraste no sentido de se obter uma melhor visualização e determinação dos pontos de interesse. 


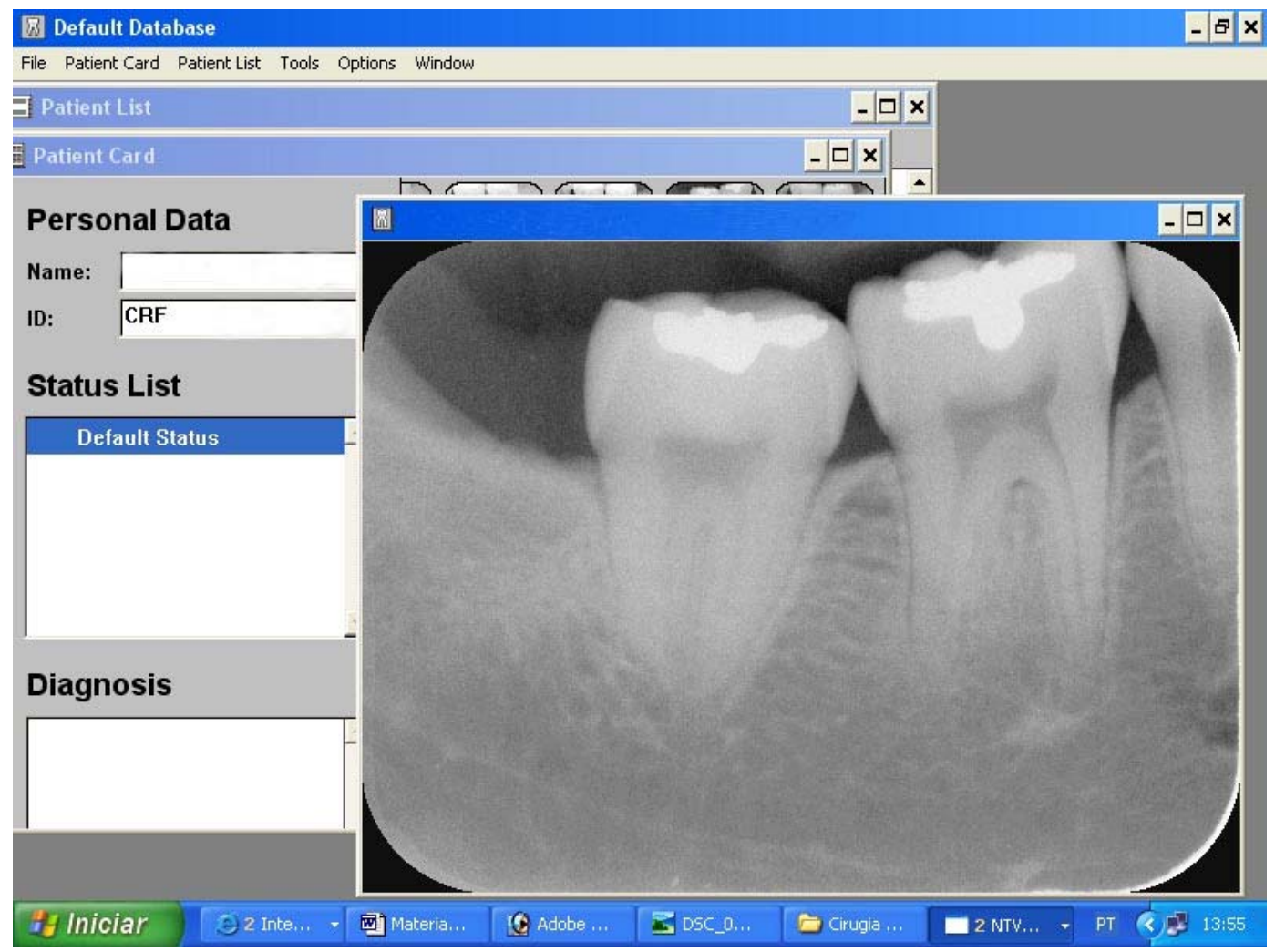

Figura 4.25 - Imagem radiográfica obtida no monitor

Uma vez obtida a imagem ideal, selecionou-se a função para medidas lineares e angulares, e através do mouse, ligaram-se os pontos de interesse numa linha reta. Automaticamente, o programa fornecia a medida em milímetros e décimos de milímetro. 


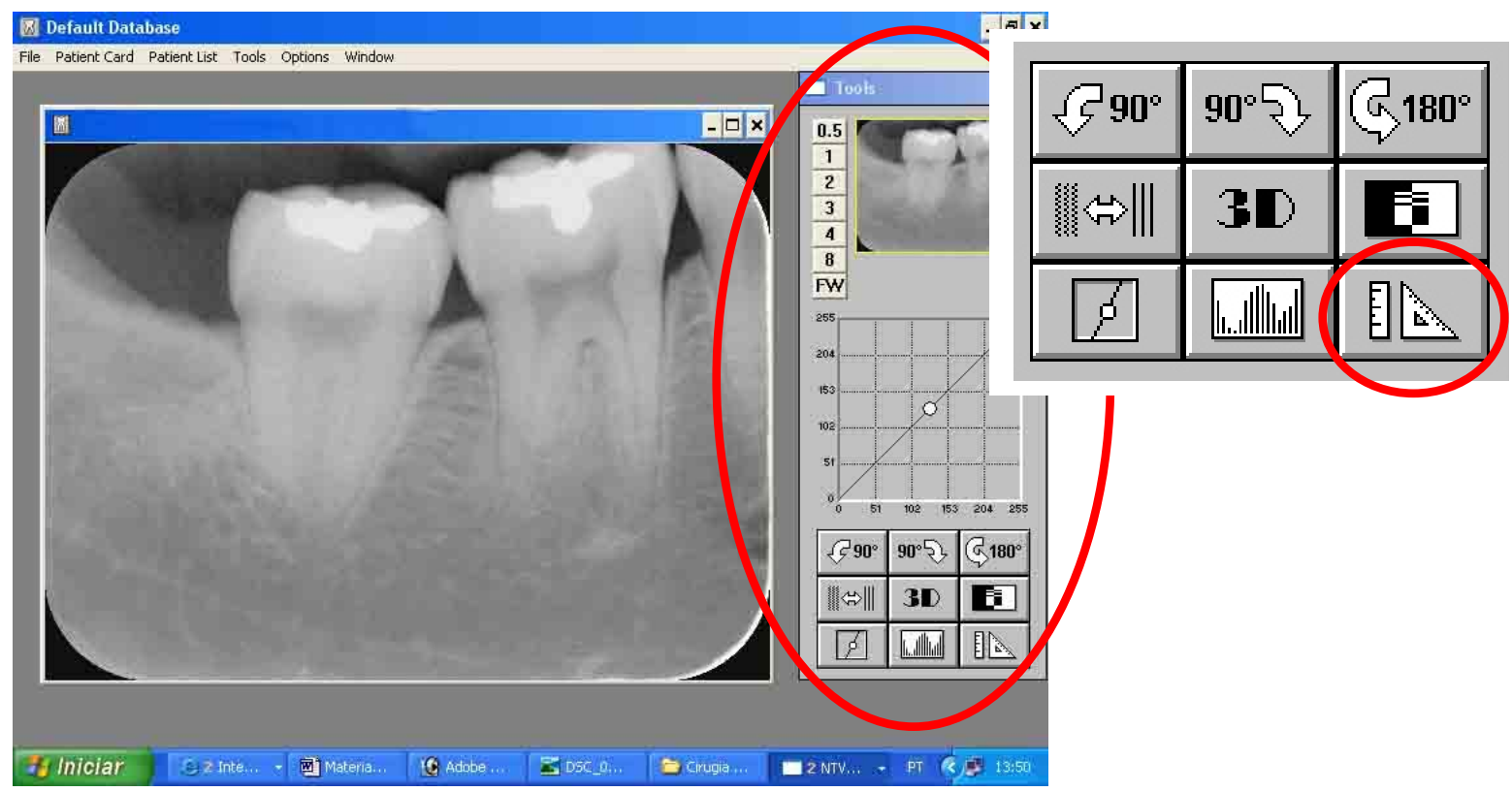

Figura 4.26 - Ferramenta de medidas lineares e angulares

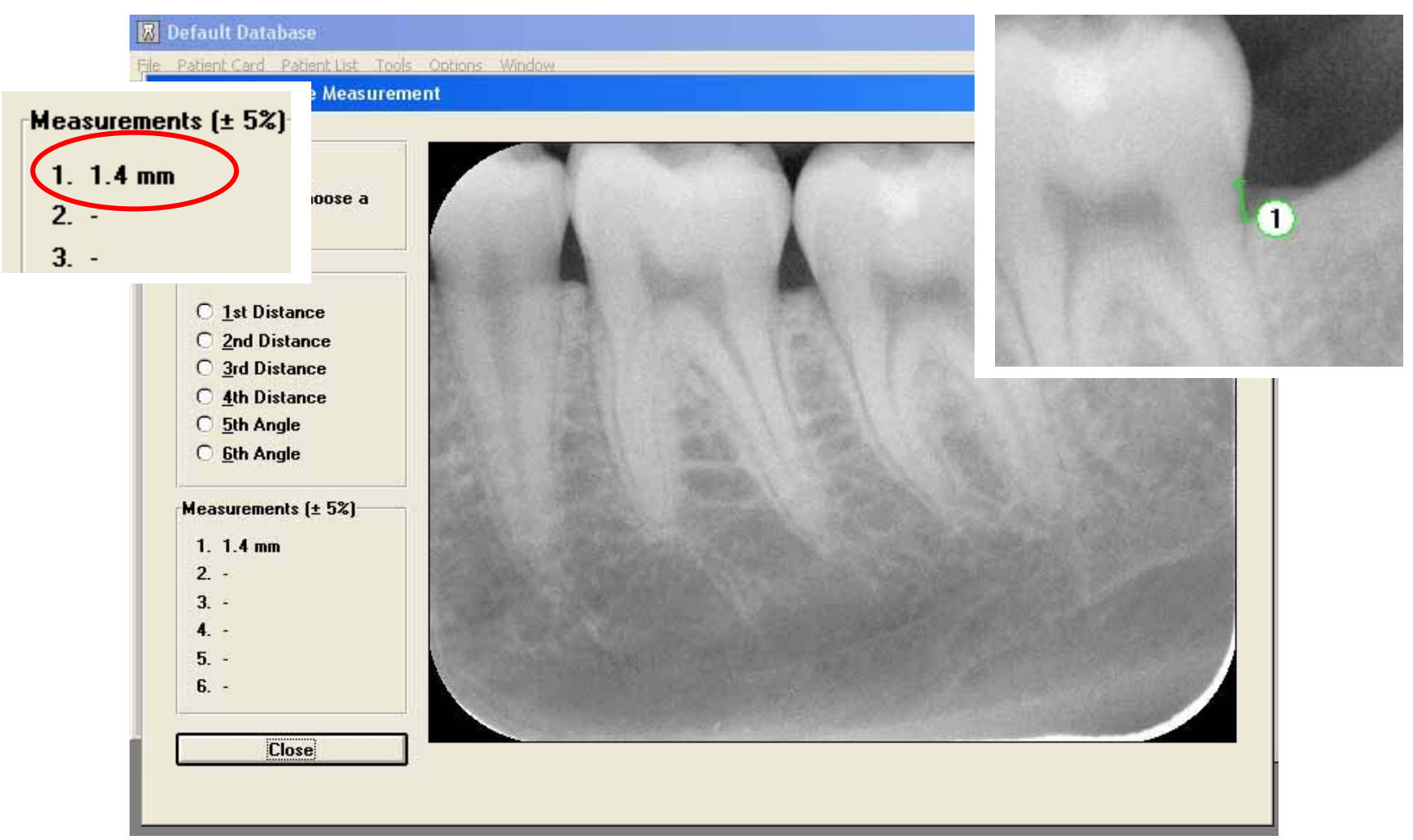

Figura 4.27 - Medição da crista óssea alveolar à junção amelo-cementária no software do Digora® 


\subsection{2 - Medida de densidade óssea}

Os valores de densidade da área do alvéolo foram obtidos por meio de radiografias periapicais digitais utilizando também o sistema Digora® (Soredex Orion Corporation).

Uma vez obtida a imagem, selecionou-se a função para medidas de densidade, e através do mouse, selecionou-se várias áreas de 30 × 30 pixels, repetindo-se até obter-se medidas de todo o alvéolo, evitando englobar áreas de cortical. Automaticamente, o programa fornecia a medida em valor de pixel (densidade óssea) que varia de 0 (preto) a 255 (branco). O número de áreas avaliadas variava conforme o tamanho do alvéolo e era repetido nas radiografias seguintes daquele grupo, obtendo-se, no final, uma média correspondente ao valor de densidade do alvéolo.

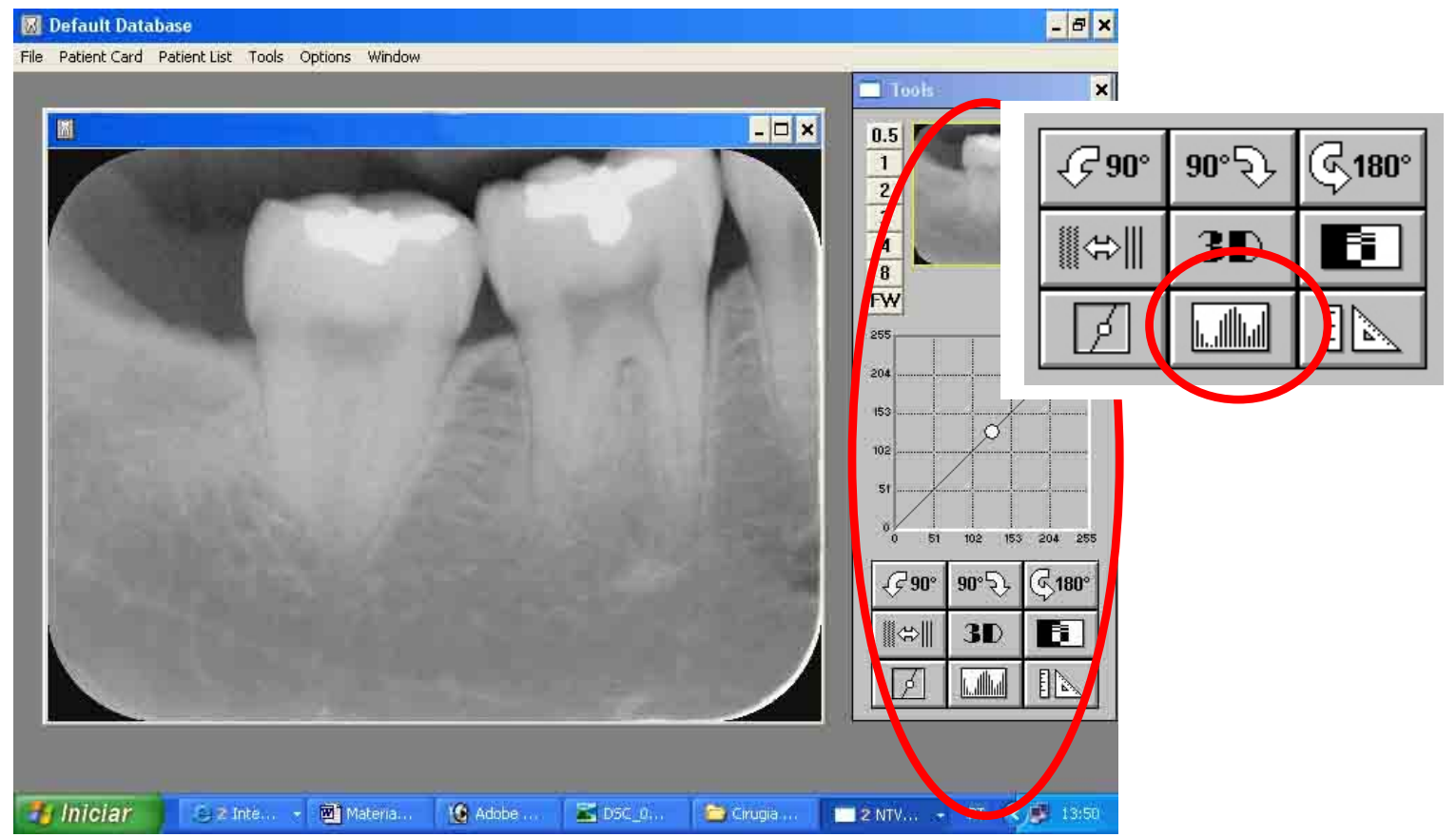

Figura 4.28 - Ferramenta de medidas de densidade (histograma) 


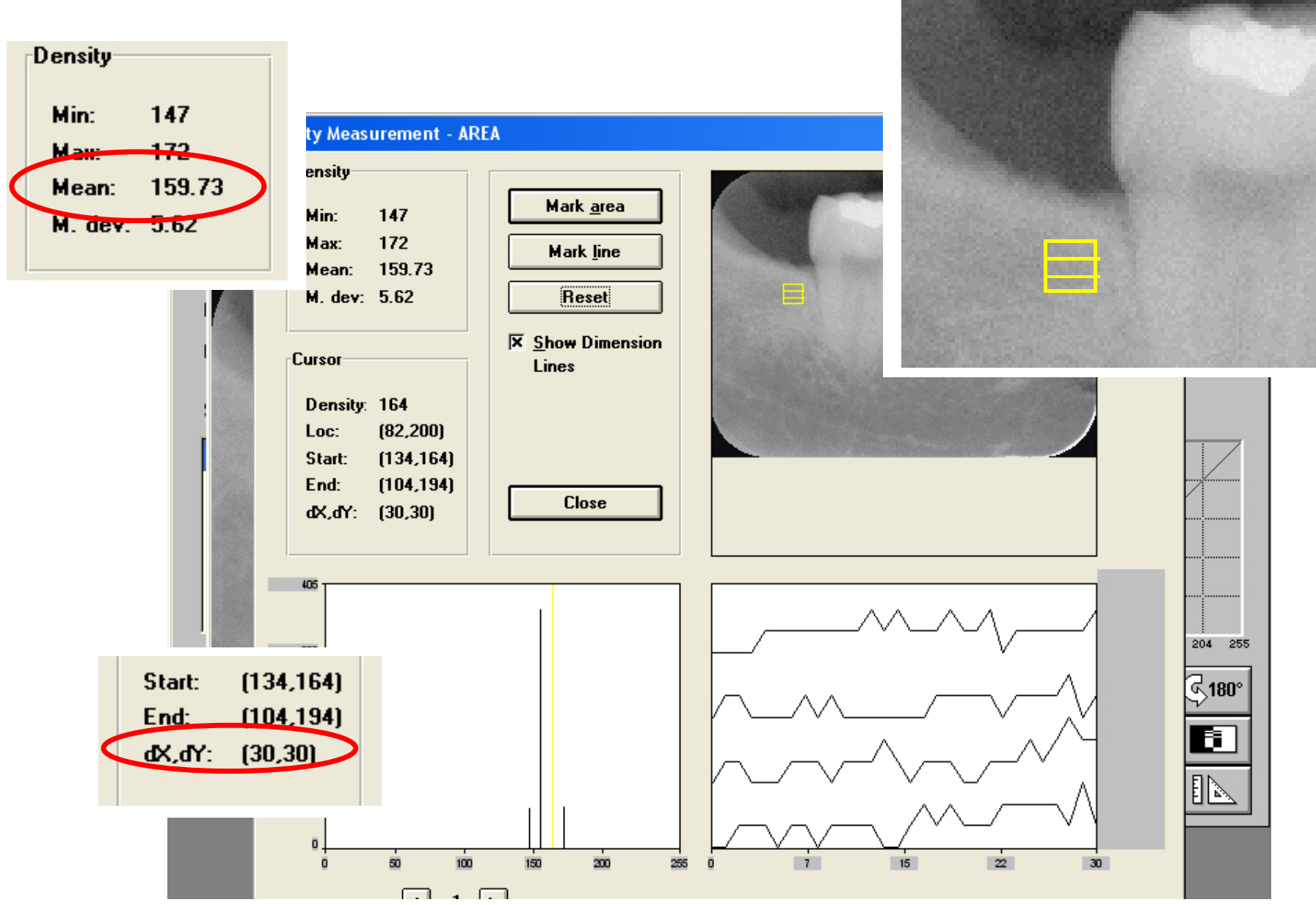

Figura 4.29 - Medição da densidade em área de 30 X 30 pixels.

Todas as imagens foram, então, armazenadas no arquivo do próprio software, individualizadas em pastas com os nomes dos pacientes. Ao ser gravada, a imagem recebeu uma legenda com as informações de data e hora da leitura do sensor, possibilitando a ordenação cronológica das imagens de um mesmo paciente ao longo do tempo. 


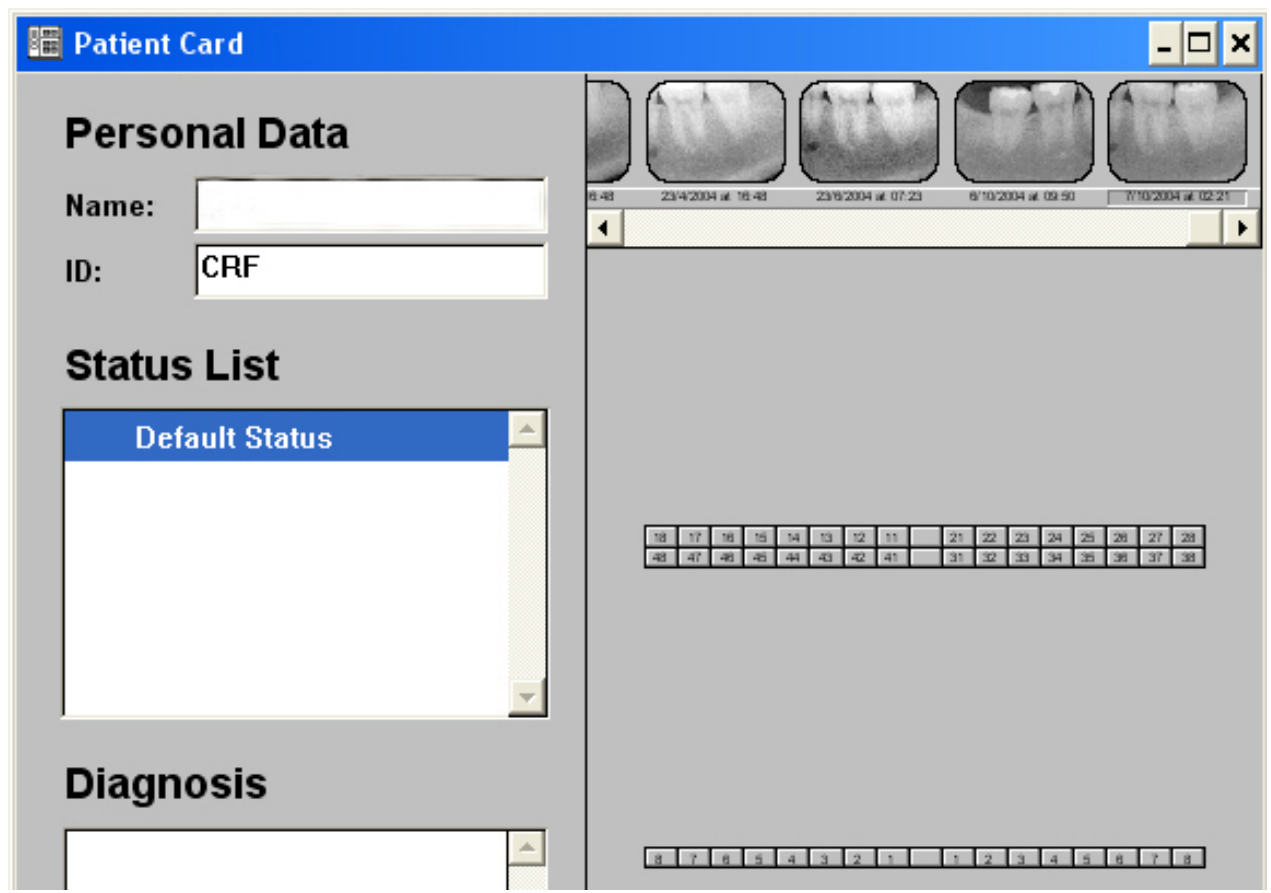

Figura 4.30 - Arquivo do paciente contendo as imagens radiográficas.

Os valores obtidos foram anotados em fichas de dados clínicos e radiográficos, que foram identificadas pelo nome do paciente e número do seu prontuário, contendo ainda a idade do paciente e a posição de seus dentes segundo a classificação de WINTER ${ }^{78}$. (Anexos C e D)

\section{8 - Períodos de avaliação}

As avaliações foram realizadas em três etapas, para posterior comparação inter e intra-grupos: (1) trans-operatório apenas para o grupo experimental, (2) pós-operatória imediata, (3) 60 dias após a exodontia e (4) 180 dias após a exodontia.

Estes tempos foram contados a partir da exodontia de cada lado, independentemente, para garantir que cada lado tivesse esses tempos pós-operatórios respeitados, não importando a diferença, em dias, entre as cirurgias de um lado e de outro; esforçando-se para que essa diferença fosse a mínima possível. 


\section{9- Tomadas radiográficas}

As tomadas radiográficas eram feitas no aparelho Yoshida Kaycor X-707, utilizando $70 \mathrm{KVP}$ e $7 \mathrm{~mA}$ e tempo de exposição de 0,20 segundos com o uso dos posicionadores.
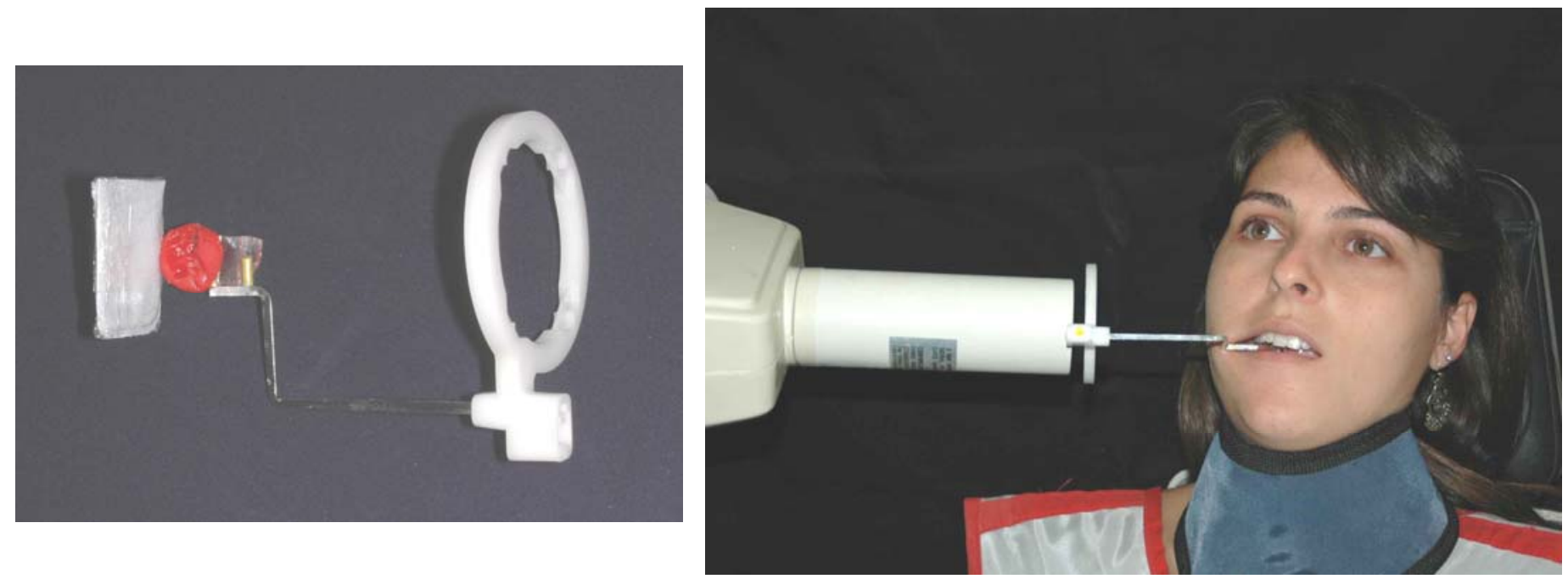

Figura 4.31 - Sensor adaptado ao posicionador radiográfico com registro oclusal e Figura 4.32 - Paciente posicionado para exame radiográfico

Durante as tomadas pós-operatórias de 60 e 180 dias, quando o paciente não estava anestesiado, o sensor, que é mais rígido que os filmes convencionais, causava grande desconforto na região sublingual dos pacientes. Para amenizar esse problema, foi utilizado anestésico tópico. 


\section{10 - Análise dos Resultados}

As medidas foram realizadas por duas vezes com intervalo de 1 semana pelo mesmo avaliador. A concordância intra-examinador durante as medidas foi avaliada através do Teste " $\mathrm{t}$ " pareado para comparar as médias e Teste de Erro de Dalberg para verificar o valor médio de erro. Para avaliar correlação das medidas foi utilizado o teste de Coeficiente de Correlação de Pearson.

Para análise dos resultados obtidos empregou-se estatística descritiva com o uso de parâmetros como média e desvio padrão.

Para análise dos dados que foram paramétricos, utilizou-se a Análise de Variância (ANOVA) a dois critérios. Para avaliar o efeito do tempo utilizou-se o Teste de Tukey.

Para certificar a diferença entre os grupos, foram realizadas ainda comparações entre as variações ao longo do tempo com o Teste "t" Pareado. Para todos os testes foi adotado nível de significância de 5\%. 
5-Resultados 


\section{RESULTADOS}

Neste capítulo serão apresentados os resultados obtidos pela aplicação da metodologia descrita através de gráficos e tabelas.

Na conclusão do trabalho a amostra consistiu de 39 pacientes devido ao abandono de um deles no período final da pesquisa, com idades entre 15 e 25 anos e média de 19,65 anos.

A distribuição dos pacientes quanto ao gênero pode ser vista na figura 5.1, enquanto que os dados individualizados de cada paciente estão no anexo D.

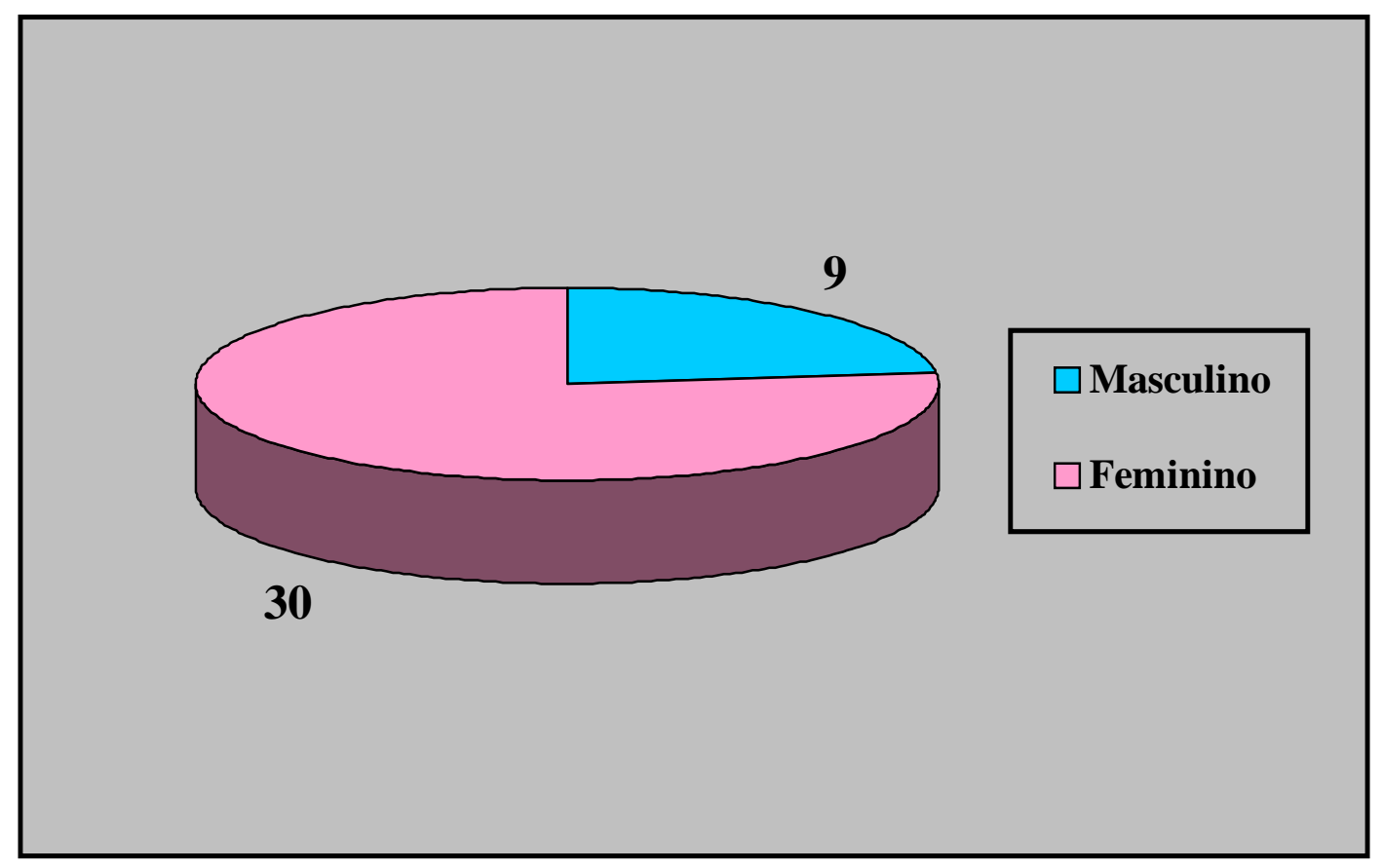

Figura 5.1 - Distribuição dos pacientes quanto ao gênero. 
Com relação à posição dos terceiros molares inferiores não-irrompidos encontrou-se 27 (69,23\%) mesioangulados, 8 (20,51\%) verticais, 4 (10,25\%) horizontais e 1 (2,56\%) distoangulado. A distribuição dos pacientes quanto à posição dos terceiros molares inferiores pode ser vista na figura 5.2, enquanto que os dados individualizados de cada paciente estão no anexo D.

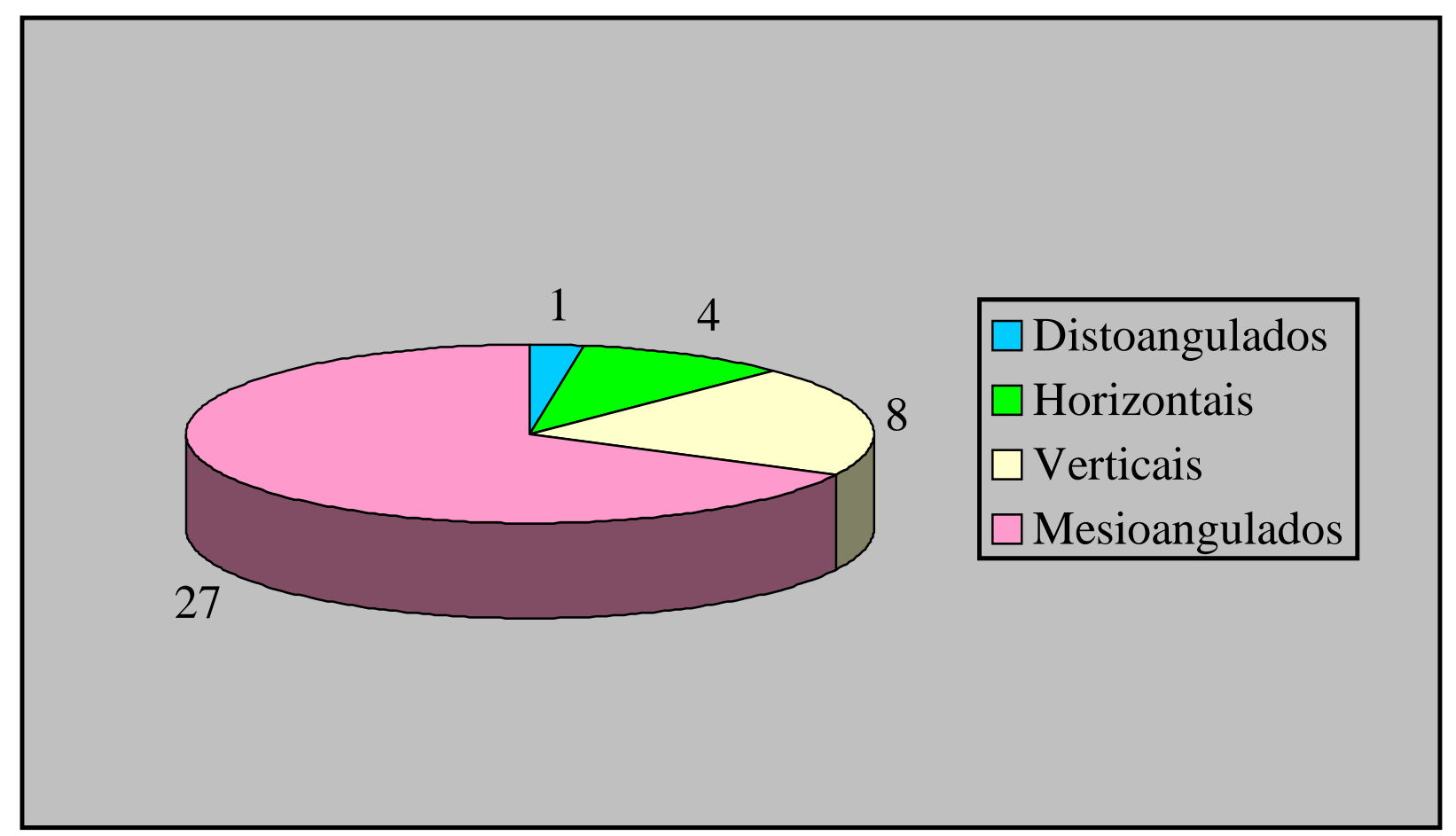

Figura 5.2 - Distribuição quanto ao posicionamento dos terceiros molares inferiores dos pacientes. 


\section{1 - Pós-operatório}

Foram registrados na ficha de cada paciente dados sobre dor e infecção no pós operatório de cada grupo de cada paciente (Anexo C).

No grupo controle houve queixa de dor em 5 pacientes, ou seja um índice de 12,82\%.

Já no grupo experimental, as queixas de dor foram relatadas por 7 pacientes, um índice de 17,94\%.

Com relação à presença de infecção, ocorreu em apenas 1 paciente no grupo controle, ou seja, 2,54\%.

No grupo experimental houve infecções em 3 pacientes, um índice de $7,69 \%$.

Essas infecções ocorreram tanto em pacientes que necessitaram de odontosecção quanto nos que não necessitaram, não havendo, portanto, interferência deste fator.

No geral houve pós-operatório bom em todos os pacientes. Os controles após 2 e 6 meses foram respeitados e apenas 1 paciente foi perdido.

\section{2 - Concordância intra-examinador}

O índice de concordância foi obtido através de repetições das medidas após 1 semana e utilizou-se o Teste " $t$ " pareado para comparar as médias. 
Para verificar os valores médios de erro utilizou-se o Teste de Erro de Dalberg. As tabelas 5.1 e 5.2 sumarizam os resultados obtidos.

Tabela 5.1 - Resultados obtidos quanto a concordância intraexaminador nas medidas de altura da crista óssea à junção amelocementária. Teste "t" Pareado e Erro de Dalberg em mm.

\begin{tabular}{cccccccc}
\hline & C & E1 & E2 & C2M & E2M & C6M & E6M \\
\hline Média 1 & 1,87 & 1,90 & 1,90 & 2,12 & 1,82 & 1,26 & 1,01 \\
DP 1 & 1,38 & 0,97 & 0,85 & 1,50 & 0,95 & 0,60 & 0,48 \\
\hline Média 2 & 1,68 & 1,76 & 1,75 & 1,75 & 1,66 & 1,16 & 0,94 \\
DP 2 & 1,24 & 0,92 & 0,85 & 1,18 & 0,99 & 0,51 & 0,44 \\
\hline $\mathbf{t}$ & 2,469 & 1,696 & 1,939 & 4,095 & 1,612 & 1,535 & 1,319 \\
$\mathbf{p}$ & $0,018^{*}$ & 0,098 & 0,060 & $0,000^{*}$ & 0,115 & 0,133 & 0,195 \\
\hline Erro & 0,36 & 0,37 & 0,35 & 0,47 & 0,46 & 0,29 & 0,23 \\
\hline
\end{tabular}

DP - desvio padrão; p - significância; * significância para p < 0,05; C- grupo controle pós-operatório imediato; E1 - grupo experimental trans-operatório; E2 - grupo experimental pós-operatório imediato; C2M - grupo controle pós-operatório de 2 meses; E2M - grupo experimental pós-operatório de 2 meses; C6M - grupo controle pós-operatório de 6 meses; E6M - grupo experimental pós-operatório de 6 meses.

A partir desses resultados pode-se afirmar que houve concordância intra-examinador nas medidas, pois na grande maioria não há diferenças significantes. 
Tabela 5.2 - Resultados obtidos quanto a concordância intraexaminador nas medidas de densidade óssea. Teste "t" Pareado e Erro de Dalberg em valores de pixel.

\begin{tabular}{cccccccc}
\hline & C & E1 & E2 & C2M & E2M & C6M & E6M \\
\hline Média 1 & 128,37 & 132,59 & 158,40 & 148,52 & 159,09 & 152,07 & 165,72 \\
DP 1 & 29,54 & 35,80 & 27,76 & 27,89 & 27,62 & 23,56 & 22,40 \\
\hline Média 2 & 126,04 & 129,29 & 160,06 & 149,18 & 158,33 & 151,07 & 166,52 \\
DP 2 & 30,86 & 36,68 & 25,67 & 27,81 & 25,76 & 25,26 & 22,90 \\
\hline t & 1,214 & 2,378 & 1,205 & 0,981 & 0,623 & 0,879 & 1,226 \\
p & 0,232 & $0,023^{*}$ & 0,236 & 0,333 & 0,537 & 0,385 & 0,228 \\
\hline Erro & 8,52 & 6,48 & 6,11 & 2,95 & 5,33 & 5,01 & 2,90 \\
\hline
\end{tabular}

DP - desvio padrão; p - significância; * significância para p < 0,05; C- grupo controle pós-operatório imediato; E1 - grupo experimental trans-operatório; E2 - Grupo experimental pós-operatório imediato; C2M - grupo controle pós-operatório de 2 meses; E2M - grupo experimental pós-operatório de 2 meses; C6M - grupo controle pós-operatório de 6 meses; E6M - grupo experimental pós-operatório de 6 meses.

A partir desses resultados pode-se afirmar que houve concordância intra-examinador nas medidas, pois na grande maioria não há diferenças significantes.

Para avaliar correlação das medidas foi utilizado o teste de Coeficiente de Correlação de Pearson. As tabelas 5.3 e 5.4 sumarizam os resultados obtidos. 
Tabela 5.3 - Resultados obtidos quanto à correlação das medidas intraexaminador para distância da crista óssea ̀̀ junção amelo-cementária. Coeficiente de Correlação de Pearson.

\begin{tabular}{cccccccc}
\hline & C & E1 & E2 & C2M & E2M & C6M & E6M \\
\hline Correlação & 0,94 & 0,86 & 0,84 & 0,94 & 0,79 & 0,75 & 0,77 \\
\hline p Correl & $0,000^{*}$ & $0,000 *$ & $0,000^{*}$ & $0,000 *$ & $0,000 *$ & $0,000 *$ & $0,000^{*}$ \\
\hline
\end{tabular}

P - significância; * significância para p < 0,05; C-grupo controle pós-operatório imediato; E 1 grupo experimental trans-operatório; E2 - Grupo experimental pós-operatório imediato; C2M - grupo controle pós-operatório de 2 meses; E2M - grupo experimental pós-operatório de 2 meses; C6M grupo controle pós-operatório de 6 meses; E6M - grupo experimental pós-operatório de 6 meses.

A partir dos resultados obtidos, pode-se afirmar que há correlação entre as medidas, sendo todas, em média, maior de 75\%.

Tabela 5.4 - Resultados obtidos quanto a correlação das medidas intra-examinador na avaliação da densidade óssea. Coeficiente de Correlação de Pearson.

\begin{tabular}{cccccccc}
\hline & C & E1 & E2 & C2M & E2M & C6M & E6M \\
\hline Correlação & 0,92 & 0,97 & 0,95 & 0,99 & 0,96 & 0,96 & 0,98 \\
\hline p Correl & $0,000 *$ & $0,000 *$ & $0,000 *$ & $0,000 *$ & $0,000 *$ & $0,000 *$ & $0,000 *$ \\
\hline
\end{tabular}

P - significância; * significância para p < 0,05; C-grupo controle pós-operatório imediato; E1 grupo experimental trans-operatório; E2 - Grupo experimental pós-operatório imediato; C2M - grupo controle pós-operatório de 2 meses; E2M - grupo experimental pós-operatório de 2 meses; C6M grupo controle pós-operatório de 6 meses; E6M - grupo experimental pós-operatório de 6 meses.

A partir dos resultados obtidos, pode-se afirmar que há correlação entre as medidas, sendo todas, em média, maior de 92\%. 
5.3 - Distância radiográfica da crista óssea à junção amelocementária

Por se tratarem de dados paramétricos, para a análise destes dados, utilizou-se a análise de variância (ANOVA) a dois critérios para medidas repetidas. Para casos onde a análise de variância mostrou diferenças estatisticamente marcantes entre as etapas analisadas (pósoperatório, 60 e 180 dias após exodontia), foi realizado o teste de Tukey para comparações múltiplas. As tabelas 5.5, 5.6 e 5.7 sumarizam os resultados obtidos. Os dados de todos os pacientes, um a um, estão disponíveis no anexo E. O gráfico da figura 5.3 ilustra o comportamento destas medidas.

Tabela 5.5 - Dados gerais obtidos da distância radiográfica da crista óssea alveolar à junção amelo-cementária.

\begin{tabular}{cccc}
\hline Variável & N & Média & Des. Padrão \\
\hline $\mathbf{C}$ & 39 & 1,6769 & 1,24085 \\
\hline E1 & 39 & 1,7615 & 0,91755 \\
\hline C2M & 39 & 1,7538 & 1,18318 \\
\hline E2M & 39 & 1,6564 & 0,9875 \\
\hline C6M & 39 & 1,1615 & 0,50815 \\
\hline E6M & 39 & 0,9436 & 0,44236 \\
\hline C2M-C & 39 & 0,0769 & 0,88182 \\
\hline C6M-C & 39 & $-0,5154$ & 1,04492 \\
\hline E2M-E1 & 39 & $-0,1051$ & 0,55343 \\
\hline F.6M-F.1 & 39 & -08179 & 074193
\end{tabular}

C - grupo controle pós-operatório imediato, C2M - grupo controle 2 meses de pósoperatório; C6M - grupo controle 6 meses de pós-operatório; El - grupo experimental transoperatório, E2M - grupo experimental 2 meses de pós-operatório; E6M - grupo experimental 6 meses de pós-operatório. 


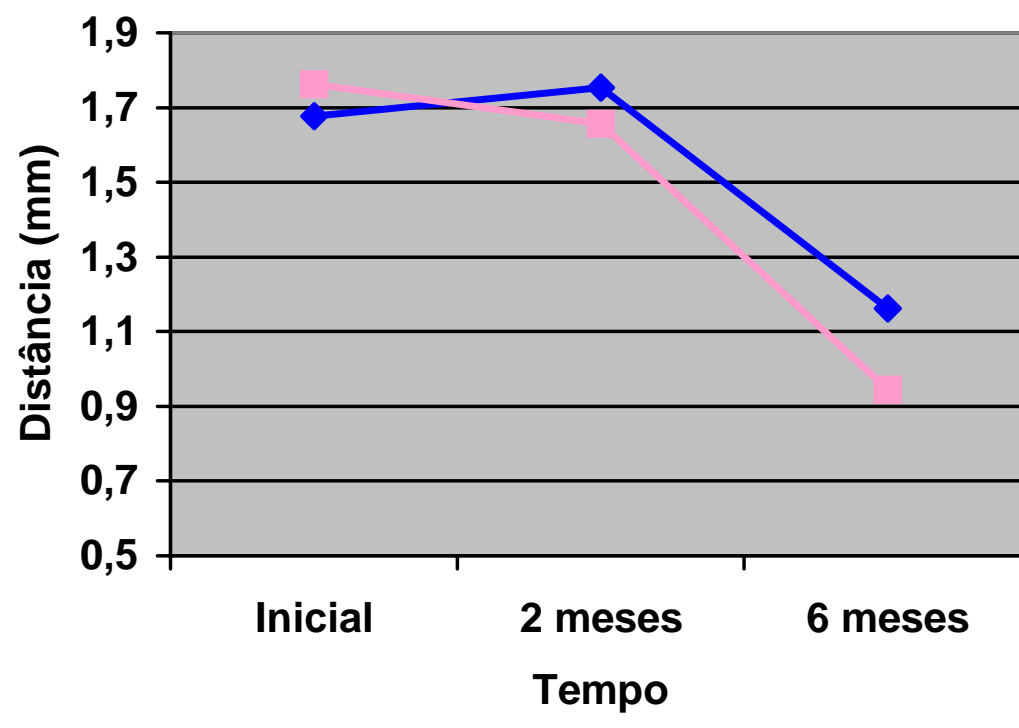

\section{$\neg$ Controle \\ Experimental}

Figura 5.3 - Evolução da distância radiográfica da crista óssea alveolar à junção amelo-cementária na distal dos segundos molares inferiores, segundo tempo analisado.

Tabela 5.6 - Resultados obtidos da distância radiográfica da crista óssea alveolar ̀̀ junção amelo-cementária. Análise de Variância a 2 Critérios (ANOVA).

\begin{tabular}{ccccccc}
\hline Efeito & df efeito & MS efeito & df erro & MS erro & F & p \\
\hline $\mathbf{1}$ & $2^{*}$ & $11,31628^{*}$ & $76^{*}$ & $0,475449 *$ & $23,80127 *$ & $\mathbf{0 , 0 0 0 0 0 0 *}$ \\
\hline $\mathbf{2}$ & 1 & 0,34615 & 38 & 0,491505 & 0,70427 & 0,4066 \\
\hline $\mathbf{1} \mathbf{2}$ & 2 & 0,45244 & 76 & 0,261603 & 1,72948 & 0,184284 \\
\hline
\end{tabular}

1 - Tempo; 2 - Grupo; p - significância; * significância para p <0,05

A análise destes resultados mostra que há diferença estatisticamente significante com relação ao tempo, mas não há diferença estatisticamente significante entre grupos e não há interação entre tempo e grupos. 
Tabela 5.7 - Resultados obtidos da distância radiográfica da crista óssea alveolar à junção amelo-cementária ao longo do tempo. Teste de Tukey.

\begin{tabular}{cccccc}
\hline & & & $\{1\}$ & $\{2\}$ & $\{3\}$ \\
Tempo & Grupo & & $\mathbf{1 , 7 1 9 2 3 1}$ & $\mathbf{1 , 7 0 5 1 3}$ & $\mathbf{1 , 0 5 2 5 6}$ \\
\hline $\mathbf{1}$ & $\ldots$ & $\{1\}$ & & 0,991129 & $\mathbf{0 , 0 0 0 1 0 9 *}$ \\
\hline $\mathbf{2}$ & $\ldots$ & $\{2\}$ & 0,991129 & \multicolumn{2}{c}{$\mathbf{0 , 0 0 0 1 0 9 *}$} \\
\hline 3 & $\ldots$ & $\{3\}$ & $\mathbf{0 , 0 0 0 1 0 9 *}$ & $\mathbf{0 , 0 0 0 1 0 9 *}$ \\
\hline
\end{tabular}

1 - pós-operatório imediato; 2 - 2 meses de pós-operatório e 3 - 6 meses de pós-operatório; * significância para $p<0,05$

A análise destes resultados mostra que os valores obtidos no pósoperatório imediato é semelhante ao de 2 meses de pós-operatório, mas tem diferença estatisticamente significante com os valores de 6 meses de pós-operatório. Mostra ainda que há diferença estatisticamente significante entre os valores de 2 meses de pós-operatório e 6 meses de pós-operatório.

Foram realizadas ainda comparações entre as variações ao longo do tempo com o Teste " $t$ " Pareado, que podem ser observadas nas tabela 5.8 e 5.9 . 
Tabela 5.8 - Resultados obtidos da distância radiográfica da crista óssea alveolar à junção amelo-cementária. Comparação entre variações, Teste " $\mathrm{t}$ " Pareado após 2 meses.

\begin{tabular}{|ccccccccc}
\hline Variável & Média & DP & N & Dif & DP Dif & t & df & P \\
\hline C2M-C & 0,76923 & 0,881823 & 39 & & & & & \\
\hline E2M-E1 & $-0,10513$ & 0,553434 & 39 & 0,1821 & 1,0076 & 1,1284 & 38 & 0,26624 \\
\hline
\end{tabular}

DP - desvio padrão; P - significância; C - grupo controle pós-operatório imediato; C2M - grupo controle 2 meses de pós-operatório; El - grupo experimental trans-operatório; E2M - grupo experimental 2 meses de pós operatório.

Tabela 5.9 - Resultados obtidos da distância radiográfica da crista óssea alveolar à junção amelo-cementária. Comparação entre variações, Teste " $\mathrm{t}$ " Pareado após 6 meses.

\begin{tabular}{|ccccccccc}
\hline Variável & Média & DP & N & Dif & DP Dif & t & df & P \\
\hline C6M-C & $-0,51539$ & 1,044922 & 39 & & & & & \\
\hline E6M-E1 & $-0,08179$ & 0,741929 & 39 & 0,3026 & 1,0179 & 1,8564 & 38 & 0,07117 \\
\hline
\end{tabular}

DP - desvio padrão; p - significância; C - grupo controle pós-operatório imediato; C6M - grupo controle 6 meses de pós-operatório; El - grupo experimental trans-operatório; E6M - grupo experimental 6 meses de pós operatório.

A análise destes resultados mostra que não houve diferença estatisticamente significante na comparação entre as variações dos períodos de tempo separadamente, nem após 2 meses, nem após 6 meses. 
5.4 - Densidade óssea radiográfica

Como mencionado anteriormente, por se tratar de dados paramétricos, assim como a distância radiográfica da crista óssea á junção amelo-cementária, a análise destes dados foi feita através da análise variância (ANOVA) a dois critérios para medidas repetidas. Para casos onde a análise de variância mostrou diferenças estatisticamente marcantes entre as etapas analisadas (pós-operatório, 60 e 180 dias após exodontia), foi realizado o teste de Tukey para comparações múltiplas. As tabelas 5.10, 5.11 , 5.12 e 5.13 sumarizam os resultados obtidos. Os dados de todos os pacientes, um a um, estão disponíveis no anexo F. O gráfico da figura 5.4 ilustra o comportamento destas medidas.

Tabela 5.10 - Dados gerais obtidos da densidade óssea radiográfica.

\begin{tabular}{cccc}
\hline Variável & N & Média & Des. Padrão \\
\hline C & 39 & 126,0413 & 30,8623 \\
\hline E1 & 39 & 129,2904 & 36,67681 \\
\hline C2M & 39 & 149,1754 & 27,80538 \\
\hline E2M & 39 & 158,3336 & 25,76143 \\
\hline C6M & 39 & 151,066 & 25,2566 \\
\hline E6M & 39 & 166,5163 & 22,90182 \\
\hline C2M-C & 39 & 23,1341 & 35,40737 \\
\hline C6M-C & 39 & 25,0247 & 37,82581 \\
\hline E2M-E1 & 39 & 29,0432 & 35,97303 \\
\hline E6M-E1 & 39 & 37,2259 & 37,30447
\end{tabular}

C - grupo controle pós-operatório imediato, C2M - grupo controle 2 meses de pós-operatório; C6M grupo controle 6 meses de pós-operatório; E1 - grupo experimental trans-operatório, E2M - grupo experimental 2 meses de pós-operatório; E6M - grupo experimental 6 meses de pós-operatório 


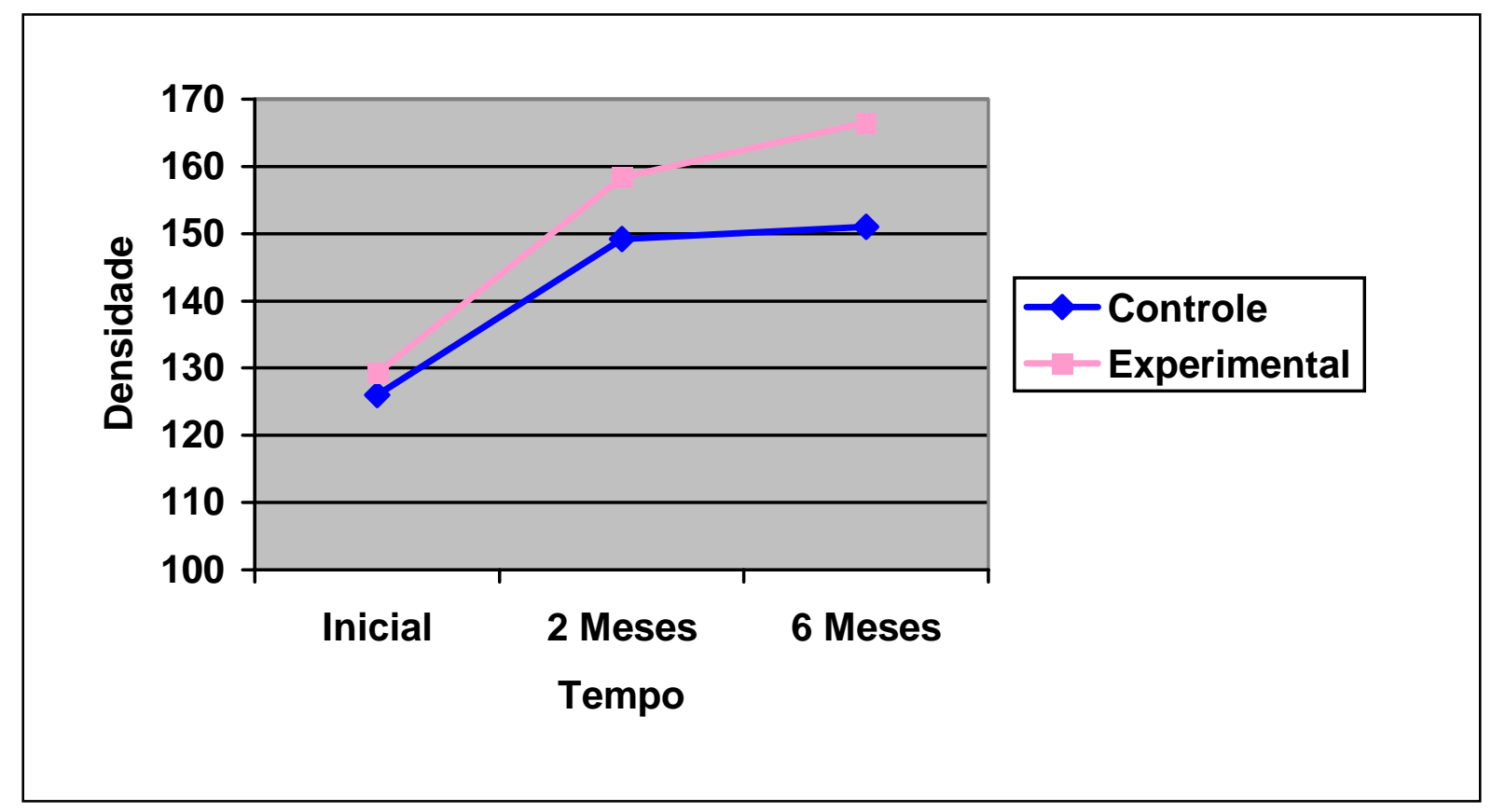

Figura 5.4 - Evolução da densidade radiográfica dos alvéolos dos terceiros molares inferiores

Tabela 5.11 - Resultados densidade óssea radiográfica. Análise de Variância a 2 Critérios (ANOVA).

\begin{tabular}{cccccc}
\hline Efeito & df efeito & MS efeito & df erro & MS erro & p \\
\hline $\mathbf{1}$ & $2^{*}$ & $21771,97^{*}$ & $76^{*}$ & $710,482^{*}$ & $\mathbf{0 , 0 0 0 0 0 0 *}$ \\
\hline $\mathbf{2}$ & $1^{*}$ & $5044,29 *$ & $38^{*}$ & $1040,481^{*}$ & $\mathbf{0 , 0 3 3 8 2 0 *}$ \\
\hline $\mathbf{1} \mathbf{2}$ & 2 & 725.98 & 76 & 585.787 & 0.295367 \\
\hline
\end{tabular}

1 - Tempo; 2 - Grupo; p - significância; * significância para p <0,05

A análise destes resultados mostra que há diferença estatisticamente significante com relação ao tempo e entre grupos e não há interação entre tempo e grupos. 
Tabela 5.12 - Resultados obtidos da densidade óssea radiográfica ao longo do tempo. Teste de Tukey.

\begin{tabular}{|c|c|c|c|c|}
\hline Tempo & Grupo & & $\begin{array}{c}\{1\} \\
1,276659\end{array}$ & $\begin{array}{c}\{2\} \\
1,705128 \\
\end{array}$ \\
\hline 1 & $\ldots$ & $\{1\}$ & & $0,000109 *$ \\
\hline 2 & $\ldots$ & $\{2\}$ & $0,000109 *$ & \\
\hline 3 & $\ldots$ & $\{3\}$ & $0,000109 *$ & 0,468736 \\
\hline
\end{tabular}

1 - pós-operatório imediato; 2 - 2 meses de pós-operatório e 3 - 6 meses de pós-operatório; * significância para $\mathrm{p}<0,05$

Tabela 5.13 - Resultados obtidos da densidade óssea radiográfica entre grupos. Teste de Tukey.

\begin{tabular}{ccccc}
\hline & & & $\{1\}$ & $\{2\}$ \\
Tempo & Grupo & & 142,0943 & 151,3801 \\
\hline$\ldots$ & 1 & $\{1\}$ & & $0,33923^{*}$ \\
\hline$\ldots$ & 2 & $\{2\}$ & $0,33923^{*}$ & \\
\hline
\end{tabular}

1 - Grupo controle; 2 - Grupo experimental; * significância para p <0,05.

A análise destes resultados mostra que os valores obtidos no pósoperatório imediato tem diferença estatisticamente significante com os valores de 2 meses de pós-operatório e com os valores de 6 meses de pós-operatório. Porem não há diferença estatisticamente significante entre os valores de 2 meses de pós-operatório e 6 meses de pósoperatório, sendo esse valores semelhantes. Mostra ainda que os valores obtidos no grupo experimental é significantemente maior que o controle em todos os tempos. 
Para certificar a diferença entre os grupos, foram realizadas ainda comparações entre as variações ao longo do tempo com o Teste " $\mathrm{t}$ " Pareado, que podem ser observadas nas tabela 5.14 e 5.15.

Tabela 5.14 - Resultados obtidos da densidade óssea radiográfica. Comparação entre variações, Teste "t" Pareado após 2 meses.

\begin{tabular}{ccccccccc}
\hline Variável & Média & DP & N & Dif & DP Dif & t & df & p \\
\hline C2M-C & 23,13409 & 35,40737 & 39 & & & & & \\
\hline E2M-E1 & 29,04322 & 35,97303 & 39 & $-5,90914$ & 52,00019 & $-0,709662$ & 38 & 0,48225 \\
\hline
\end{tabular}

DP - desvio padrão; P - significância; C - grupo controle pós-operatório imediato; C2M grupo controle 2 meses de pós-operatório; El - grupo experimental trans-operatório; E2M - grupo experimental 2 meses de pós operatório.

Tabela 5.15 - Resultados obtidos da densidade óssea radiográfica. Comparação entre variações, Teste "t" Pareado após 6 meses.

\begin{tabular}{ccccccccc}
\hline Variável & Média & DP & N & Dif & DP Dif & t & df & p \\
\hline C6M-C & 25,02466 & 37,82581 & 39 & & & & & \\
\hline E6M-E1 & 37,22586 & 37,30447 & 39 & $-12,2012$ & 47,18839 & $-1,61473$ & 38 & 0,11464 \\
\hline
\end{tabular}

DP - desvio padrão; p - significância; C - grupo controle pós-operatório imediato; C6M - grupo controle 6 meses de pós-operatório; E1- grupo experimental trans-operatório; E6M - grupo experimental 6 meses de pós operatório.

A análise destes resultados mostra que não houve diferença estatisticamente significante na comparação entre as variações ao longo do tempo, nem após 2 meses, nem após 6 meses. 


$$
\underline{6-\text { Discussão }}
$$




\section{DISCUSSÃO}

\section{1 - Posição dos terceiros molares inferiores}

Com relação à posição dos terceiros molares inferiores não-irrompidos encontrou-se um índice de 69,23\% para mesioangulados, 20,51\% para verticais, 10,25\% para horizontais e 2,56\% para distoangulados.

Os resultados encontrados na literatura variam. SANT'ANA, FERREIRA JR \& PINZAN ${ }^{60}$, em 2000, avaliando a freqüência de posição dos terceiros molares inferiores não-irrompidos encontraram um índice de 49,64\% de mesioangulados, 41,9\% de verticais, 4,57\% de horizontais e 2,81\% para distoangulados em pacientes com idade entre 14 e 19 anos. Já nos pacientes com idade entre 20 e 25 anos, os índices encontrados foram de 31,17\% para mesioangulados, 48,82\% para verticais, 11,47\% para distoangulados e 6,76\% para horizontais. Os autores observaram também que a freqüência de terceiros molares inferiores mesioangulados é maior em pacientes mais jovens e diminui à medida que a idade aumenta.

Como a amostra do presente estudo constituiu de pacientes com idades entre 15 e 25 anos, os índices parecerem ser similares à média encontrada pelos autores ${ }^{60}$.

VAN-DER-LINDER et al ${ }^{73}$, em 1995 tiveram índices diferente dos encontrados, com relação aos mesioangulados (36,6\%) e distoangulados (19,4\%), mas parecidos com relação aos verticais (21,2\%) e horizontais (17,2\%), em pacientes com idade entre 10 e 79 anos, sendo a maioria entre 10 e 29 anos. 
Outros autores mostram também índice maior de verticais com relação a mesioangulados. BOER et al ${ }^{8}$, em 1995 , encontraram um índice de verticais de 57\% e de mesioangulados de 22\% e um número parecido com o resultado de horizontais (13\%) e distoangulados (6\%), em amostra de pacientes entre 16 e 30 anos.

Também BATAINEH, ALBASHAIREH \& HAZZA ' $A^{5}$, em 2002, encontraram indice de 61,41\% de verticais, 18, 07\% de mesioangulados, 6,8\% de horizontais e 4,68\% de distoangulados e maior parte da amostra era constituída de pacientes entre 20 e 25 anos.

Pode-se dizer, então que a posição dos terceiros molares inferiores varia bastante dependendo da amostra e da idade dos pacientes.

\section{2 - Controle Pós-operatório de 7 a 14 dias}

No pós-operatório de 7 a 14 dias, queixa de dor foi relatada por 12,82\% pacientes do grupo controle e 17,94\% do experimental.

Já o índice de infecção foi de 2,54\% no grupo controle e 7,69\% no experimental. $\bigcirc$ índice de infecção pode ter sido um pouco maior no lado experimental devido à ocorrência de exposição da membrana, porque, mesmo que houvesse preocupação em realizar-se uma boa sutura, na região do alvéolo dos terceiros molares inferiores, pode ocorrer uma deiscência que pode expor a membrana. 
Como essas infecções ocorreram tanto em pacientes que necessitaram de odontosecção quanto nos que não necessitaram, em ambos os grupos, este não pode ser considerado um fator relacionado a um índice maior de infecção.

Em exodontias de 2390 terceiros molares inferiores sem o uso de biomateriais, BOER et al ${ }^{8}$, em 1995 encontrou 8 casos de alveolite e 34 de abscesso, um índice de 1,75\%, inferior ao encontrado durante esta trabalho.

Já PETRI \& WILSON ${ }^{54}$, em 1993, em estudos de enxerto ósseo alógeno desmineralizado associado a antibióticos e não encontrou nenhum caso de infecção entre os 25 pacientes de sua amostra. Apesar de todos os pacientes do presente estudo fazerem uso de antibióticos por via oral, houve 3 casos de infecção, o que diferem destes resultado obtido por PETRI \& WILSON ${ }^{54}$ onde houve aplicação de antibióticos no alvéolo. Porém um índice de 7,69\%, encontrado no presente estudo, não pode ser considerado significante.

6.3 - Distância da crista óssea alveolar à junção amelocementária:

A medida da distância da crista óssea alveolar à junção amelo-cementária tem sido usada como parâmetro para avaliar o reparo na distal de segundos molares adjacentes aos terceiros molares inferiores após sua exodontia e também para avaliação após terapia periodontal em defeitos ósseos. (KUGELBERG et al ${ }^{34,35,36,37}$, 1985, 1986, 1990, 1991, MARMARY et al ${ }^{42}, 1986$, ESLAMI, SADEGHI \& 
VAN SWOL ${ }^{17}$, em 1985, HAUSMANN, et al ${ }^{25,26}, 1989$, BISHP et al ${ }^{6}$, 1995, DODSON ${ }^{15}$, 1996, THRONDSON \& SEXTON ${ }^{71}, 2002$ e GIGLIO20, 2003.)

Muitos desses trabalhos avaliaram também o índice de placa, índice gengival e sondagem periodontal no pós-operatório desses pacientes. (KUGELBERG et al ${ }^{34,37}, 1990,1991$, DODSON ${ }^{15}$, 1996, THRONDSON \& SEXTON¹, 2002 e GIGLIO 20 , 2003).

Nos trabalhos de ASH, COSTICH \& HAYWARD ${ }^{4}$, em 1962, OSBORNE, SNYDER \& TEMPEL ${ }^{49}$, em 1982, KUGELBERG et $\mathrm{a}^{35}$, em 1985, KUGELBERG ${ }^{34}$, em 1990, e DODSON ${ }^{15}$, em 1996, não houve significância no que diz respeito ao índice de placa e índice gengival. Esses parâmetros podem ser muito suscetíveis à higiene local e à simples presença ou não de um terceiro molar nãoirrompido na região, conforme relatado em alguns dos trabalhos $21,23,35,37$

Com relação à sondagem OSBORNE, SNYDER \& TEMPEL $^{49}$, em 1982 e KUGELBERG ${ }^{34}$, em 1990 não encontraram diferenças significantes. Já KUGELBERG et al ${ }^{37}$, em 1991, encontram diferenças entre o pós-operatório imediato e 3 meses após, mas essas medidas continuaram semelhantes após 1 ano.

DODSON ${ }^{15}$, em 1996, após enxerto de osso desmineralizado também encontrou uma diminuição na profundidade de sondagem após 6 meses de 3,1 para 1,4 no grupo controle e de 3,3 para 0,6 no grupo experimental. Já THRONDSON e SEXTON ${ }^{71}$, em 2002 após enxerto com cerâmica bioativa encontrou diferenças comparando os controles após 3 e 12 meses com relação à sondagem, porém não foi significante com relação ao tempo. 
Conforme estudos de OSBORNE, SNYDER \& TEMPEL ${ }^{49}$, em 1982, MEISTER JR et al ${ }^{44}$, em 1986 e KUGELBERG et al ${ }^{37}$ em 1991 , a extração dos terceiros molares por si só promovem melhora na profundidade de sondagem da distal dos segundos molares, porém não alcança os valores considerados ideais.

Alguns autores também sugerem que as reduções observadas na profundidade de sondagem de seus trabalhos podem ser explicadas pela redução do edema inflamatório presente e, portanto, da chamada falsa bolsa, resultando em uma menor penetrabilidade dos tecidos pela sonda, o que não representa um ganho de inserção ${ }^{36,23}$.

Portanto, há limitações na sondagem no sentido de aferir a efetividade de uma terapia, pois o ganho de inserção obtido na sondagem não fornece informações à respeito da natureza da inserção formada, que pode ser desde uma firma adaptação do epitélio juncional, alongado, até uma real formação de nova inserção. (PARODI \& ESPER ${ }^{50}, 1984$ ).

No presente trabalho foi proposto apenas exames radiográficos para avaliar o reparo periodontal na distal dos segundos molares adjacentes.

O método de medida da distância da crista óssea alveolar mostrou ter boa concordância intra-examinador, como pode ser visto no teste de correlação realizado neste trabalho, e, com isso, boa reprodutibilidade. $\bigcirc$ uso de registros oclusais e a realização de medidas a partir de pontos anatômicos podem explicar essa boa concordância. 
DUINKERKE et al ${ }^{16}$, em 1977, avaliando uma técnica para padronização de radiografias periapicais mostrou que o uso de registros oclusais possui um erro muito pequeno na sua reprodutibilidade, por volta de 0,05 mm nas medidas realizadas.

JEAN et al ${ }^{30}$, em 1996, utilizando registros oclusais e posicionadores RINN XCP conseguiram quantificar a variação de quantidade óssea nos sitios periodontais avaliados e concluíram que o método é eficiente.

Já BISHOP et al ${ }^{6}$, em 1995 mostrou que também houve grande concordância na habilidade de medir a distância entre a junção amelo-cementária e a crista óssea alveolar nas mesmas radiografias e esta técnica de medida foi considerada aplicável.

KUGELBERG et a ${ }^{36}$, em 1986 também afirmou haver grande índice de correlação na medida da altura da crista óssea alveolar à junção amelo-cementária.

Os resultados obtidos no presente trabalho com relação à medida da distância da crista óssea alveolar à junção amelocementária foi uma diminuição dessa medida significante ao longo do tempo, com 2 e 6 meses de pós-operatório, mas não foi estatisticamente significante a diferença entre grupos.

Outros estudos também realizaram essa medida após exodontia de terceiros molares inferiores associado ou não à uma terapia para avaliar o reparo periodontal na distal dos segundos molares inferiores e também para comparações entre grupos experimental e controle.

Muitos trabalhos mostram que há uma redução significativa ao longo do tempo da medida da distância da crista 
óssea alveolar à junção amelo-cementária após extração dos terceiros molares inferiores, como ocorreu no presente estudo.

MEISTER et al $^{44}$, em 1986 compararam grupos de pacientes com terceiros molares inferiores parcialmente irrompidos e não-irrompidos e verificaram que, 6 meses após a extração, houve redução da distância entre a crista óssea alveolar e a junção amelocementária, mas não houve diferenças entre os grupos.

Também MARMARY et al ${ }^{42}$, em 1996, avaliaram o pósoperatório de pacientes após extração de terceiros molares inferiores, com controles após 6 meses e 4 anos e concluíram que houve diminuição na distância da crista óssea alveolar à junção amelocementária ao longo do tempo, no entanto essa redução foi significantemente maior nos grupos com idade entre 20 e 29 anos do que no grupo com idade entre 30 e 50 anos.

KUGELBERG ${ }^{34}$, em 1990, comparou o pós-operatório de pacientes com até 25 anos e com mais de 26 anos após 2 e 4 anos de extração dos terceiros molares inferiores, mostrando que no grupo mais jovem houve diminuição da distância significantemente maior que no grupo com mais idade, enfatizando a importância da idade no reparo periodontal da região distal dos segundos molares adjacentes.

Juntamente com outros autores, KUGELBERG ${ }^{37}$, em 1991, avaliando pós-operatório de 3 meses e 1 ano em grupos de pacientes até 20 anos e maiores de 30 anos mostraram que houve uma melhora significativa apenas no grupo mais jovem. Afirmaram também que em defeitos com mais de 4 mm, houve melhora após 1 
ano em 90\% dos pacientes com menos de 20 anos e em apenas 49\% no grupo com mais de 30 anos.

THRODSON \& SEXTON¹, em 2002, realizaram um estudo com 14 pacientes com idade superior a 25 anos, onde enxertaram cerâmica bioativa em alvéolos de terceiros molares inferiores não-irrompidos. Avaliando radiografias pré-operatórias e pós-operatórias de 6 e 12 meses, os autores encontraram uma diferença significante comparando 6 e 12 meses, mas não houve diferenças entre os grupos, mostrando um resultado semelhante ao presente estudo, mesmo a amostra sendo de pacientes com idade superior a 25 anos.

Também GIGLIO20, em 2003, em sua dissertação de mestrado, avaliando aplicação de ácido cítrico na distal dos segundos molares adjacentes e com controles de pós-operatório de 3 e 6 meses em 29 pacientes com até 25 anos, utilizando a mesma metodologia, obteve resultados semelhantes ao presente estudo, onde houve uma melhora significante ao longo do tempo, mas sem diferença entre o grupo controle e experimental, sugerindo que a extração do terceiro molar por si só já melhora as condições de higiene e os parâmetros de saúde periodontal na região distal dos segundos molares adjacentes.

Os resultados obtidos neste estudo, portanto, condizem com os achados na literatura em geral, principalmente nos estudos com pacientes jovens.

Pode-se sugerir que talvez, se houvesse um grupo de pacientes acima de 25 anos, ocorresse alguma diferença entre os grupos de idade mais jovem e mais velho e também entre o grupo 
experimental e controle, já que em pacientes mais jovens, a simples remoção dos terceiros molares já melhora a condição periodontal dos segundos molares adjacentes, o que não acontece sempre nos grupos com idades superiores ${ }^{34,37,42}$. Seria interessante também controles pós-operatórios mais tardios dessa amostra, após 1, 2 e até 4 anos, como visto em alguns trabalhos aqui discutidos $34,35,37,42,49,71$ para avaliar se essa saúde periodontal se mantém.

\section{4 - Medidas de densidade óssea}

Os resultados obtidos no presente estudo foram de um aumento no valor da densidade óssea significante ao longo do tempo para os dois grupos e significantemente maior no grupo experimental.

Para controle foram utilizadas radiografias periapicais digitais diretas: 1 - no trans-operatório do grupo experimental, com o alvéolo vazio, apenas com sangue, 2 - no pós-operatório imediato, com o material de enxerto no grupo experimental e apenas sangue no grupo controle, 3 - no pós-operatório de 2 meses e 4 - no pósoperatório de 6 meses.

A princípio, pretendia-se utilizar o valor da diferença entre o alvéolo vazio e o pós-operatório imediato como o valor de radiopacidade do material para descontar no valor encontrado nos controles.

Porém, em estudos histológicos que avaliaram enxerto de matriz óssea inorgânica, como por exemplo, o BioOss ${ }^{\circledR}$, observase que após 6 meses parte do material já foi absorvida pelo 
organismo e outra parte ainda está presente, mas interagindo com matriz óssea neoformada.

CARMAGNOLA, ADRIAENS \& BERGLUNDH'11, em

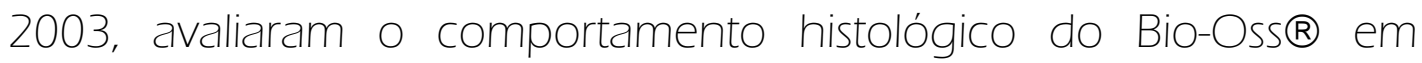
alvéolos dentários e observaram que após 7 meses 18\% da constuição óssea local eram ainda partículas do biomaterial e que 40\% dessas partículas estavam em íntimo contato com o osso neoformado.

HIROTA, REZENDE \& GRANJEIRO ${ }^{28}$, em 2003 em estudo histológico com o mesmo biomaterial utilizado no presente estudo (Gen-tech®) após levantamento de seio encontram 29\% de osso neoformado após 6 meses e ausência de inflamação.

sICCA ${ }^{62}$, em 2005, avaliando o mesmo material, também encontrou grande parte de material inorgânico presente e com tecido ósseo neoformado em íntimo contato após 8 semanas, em levantamento de seio maxilar de coelhos.

De acordo com os resultados encontrados na literatura, onde, após um período de 6 meses, parte desse material foi absorvido e parte ainda está presente no alvéolo, interagindo com o osso neoformado, se fosse subtraído o valor de radiopacidade do material obtido no início, não teríamos um valor real. Após testes vimos que o ganho de densidade teria valores negativos após 6 meses. Como parte do material já foi absorvido, estaria descontandose osso neoformado.

A partir dessa análise, optou-se por utilizar os valores de densidade inicial do alvéolo sem o material (C e El), apenas preenchido por sangue e os valores de densidade após 2 meses 
(C2M e E2M) e após 6 meses (C6M e E6M), sem descontar o valor de radiopacidade do material no grupo experimental.

Os resultado obtidos, através da Análise de variância a dois critérios (ANOVA) e Teste de Tukey mostraram de que houve uma diferença estatisticamente significante entre os grupos controle e experimental no que diz respeito à medida de densidade e de que os valores do grupo experimental foram maiores que os do controle.

Como visto na literatura, ainda há material presente no alvéolo. Portanto, não podemos afirmar que esse valor é real, pois é provável que tenha sido maior devido à presença de parte do material.

Após avaliação desses resultados, para certificar a diferença entre os grupos, foram realizadas ainda comparações entre as variações ao longo do tempo com o Teste "t" Pareado. Neste teste foram comparados os grupos controle e experimental no que diz respeito às variações em determinados tempos (entre inicial e 2 meses e entre inicial e 6 meses).

A análise destes resultados mostra que não houve diferença estatisticamente significante na comparação entre as variações ao longo do tempo, nem após 2 meses, nem após 6 meses. Portanto, apesar de haver uma diferença entre grupos, comparando eles separadamente nos períodos citados, o aumento da densidade não foi diferente, mostrando que tanto o grupo controle (coágulo), como o grupo experimental (material), tiveram um comportamento semelhante ao longo do tempo, com ganho gradual de densidade.

Porém, analisando o gráfico da figura 5.4 pode ser observado que os valores de densidade do grupo controle e experimental inicial são semelhantes, pois ambos são de alvéolos apenas 
preenchidos por sangue. Já quando se observa os valores após 2 meses e 6 meses, onde há material de enxerto no grupo experimental, os resultados são contrastantes. A diferença entre os valores do grupo controle e experimental é maior no período de 6 meses, quando parte do material foi reabsorvido e não no período de 2 meses, quando há maior quantidade do material. Esse achado pode levar a suspeita de que apesar de ainda haver material, houve neoformação óssea maior no grupo experimental após 6 meses.

PETRI \& WILSON ${ }^{54}$, em 1993 utilizaram medidas de densidade para avaliar o pós-operatório de 6 meses de enxerto de osso alógeno desmineralizado em alvéolos de terceiros molares inferiores comparado com coágulo no grupo controle. As medidas foram realizadas com um densitômetro que analisou a densidade do filme radiográfico nos sítios de extração por transmissão de lumens, e a densidade foi significantemente maior nos alvéolos experimentais. Porém não houve medidas de densidade ao longo do tempo para acompanhar a evolução e nem inicial para quantificar o ganho de mineral, apenas comparou-se os resultados de 6 meses, não sendo este um resultado confiável.

A utilização de medidas de densidade óssea ou valores de pixel em imagens digitais mostra-se uma técnica eficiente para detectar o ganho de minerais durante o reparo ósseo. (KHOCHT et al ${ }^{32}, 2003$, KULLUNDORFF, NILSSON \& ROHLIN ${ }^{38}, 1996$, TAVANO et al ${ }^{69}, 19991$.

As medidas de densidade no presente trabalho foram realizadas por duas vezes com um intervalo de 7 dias e foram realizados testes para verificar a concordância intra-exarminador nos valores de densidade obtidos. Todos os testes realizados resultaram em uma boa 
concordância, mostrando que esse método de medida possuiu uma excelente reprodutibilidade.

TAVANO et al69, em 1999, em um estudo comparando a análise subjetiva da densidade óssea após implantes de polímero de mamona em rádio de coelhos, com a análise digital e concluíram que as imagens digitais obtidas pelo sistema Digora® oferecem melhores condições de visualização, objetividade e precisão para realização da interpretação radiográfica da evolução do reparo ósseo, tanto nos grupos controle como experimental.

KULLUNDORFF, NILSSON \& ROHLIN ${ }^{38,39}$, em estudos em 1996, também comparando sistema convencional e digital na detecção de lesões periapicais, afirmaram que a qualidade das imagens digitais diretas são comparáveis a filmes convencionais com velocidade E na detecção de lesões periapicais e que a manipulação da imagem como alterações de brilho e contraste não interfere na detecção dessas lesões.

VERSTEEG et al ${ }^{74}$, em 1998 também avaliaram o efeito nas alterações de brilho e contraste automática utilizada por uma ferramenta do Sistema Digorå e também concluíram que a manipulação não interfere no diagnóstico de lesões periapicais.

Outro método utilizado para detecção de ganho mineral é a subtração de imagem. (JEAN et al ${ }^{30}$, 1996). Para a realização da subtração é necessária uma padronização das radiografias realizadas, que devem ser perfeitamente na mesma posição para poderem ser subtraídas.

Mesmo havendo uma maior radiopacidade no grupo experimental, não se pode afirmar que há maior neoformação óssea no local, pois essa radiopacidade maior pode ser devido ao material 
inorgânico ainda presente no alvéolo. Para verificar a quantidade de osso neoformado e a qualidade do mesmo seria necessária a avaliação histológica do enxerto.

HIROTA, REZENDE \& GRANJEIRO ${ }^{28}$, em 2003 encontraram a presença de aproximadamente 29\% de osso neoformado após 6 meses, tanto nas áreas utilizando o mesmo material do presente estudo /Gentech®), como nas áreas utilizando-se enxerto de osso autógeno, mostrando que esse material pode ser um bom substituto de osso autógeno para levantamento de seio maxilar.

Por se tratar de pacientes com terceiros molares inferiores indicados para exodontia, com os segundo molares adjacentes presentes e íntegros, nenhum deles necessitaria de implantes na região. A biópsia de osso nessa área não poderia ser realizada devido a princípios éticos. Por isso, sugere-se estudo com enxertos desse material em alvéolos que posteriormente necessitem de implantes, para haver a possibilidade de avaliação histomorfométrica da área após o enxerto.

Considerando-se as limitações do modelo experimental e da metodologia empregada, pode se dizer que o material teve um comportamento aceitável e que pode ser utilizado como material de enxerto na área estudada, que foi escolhida devido a sua possibilidade de padronização e reprodutibilidade.

Sugere-se também que haja controles mais tardios dessa amostra, após 1 e 2 anos, quando já não haverá mais material na área e pode-se obter um valor real de densidade óssea que possibilite uma melhor comparação entre grupos. 
7 - Conclusões 


\section{CONCLUSÕES}

Como apresentado no capítulo de resultados, podemos observar que:

1 - A distância radiográfica da crista óssea alveolar à junção amelo-cementária apresentou redução significante ao longo do período analisado, porém não houve diferenças estatisticamente significantes entre os grupos.

2- A extração dos terceiros molares inferiores não-irrompidos resultou em benefícios quanto às condições periodontais radiográficas dos pacientes.

3 - A densidade óssea aumentou significativamente ao longo de período analisado nos dois grupos e foi significativamente maior no grupo experimental. Porém, analisando a variância nos períodos de tempo separadamente, não houve diferenças significantes entre os grupos.

Isto nos permite concluir que o Gen-techß, associado ̀̀ membrana Gen-Derm® teve comportamento semelhante ao coágulo nos critérios analisados. 
Anexos 


\begin{abstract}
ANEXOS
Anexo A - Modelo do Termo de Consentimento Livre e Esclarecido
\end{abstract}

TERMO DE CONSENTIMENTO LIVRE E ESCLARECIDO

Pelo presente instrumento que atende às exigências legais, o Sr. (a)

portador da cédula de identidade , após leitura minuciosa da CARTA DE INFORMAÇÃO AO PACIENTE, devidamente explicada pelos profissionais em seus mínimos detalhes, ciente dos serviços e procedimentos aos quais será submetido, não restando quaisquer dúvidas a respeito do lido e explicado, firma seu CONSENTIMENTO LIVRE E ESCLARECIDO concordando em participar da pesquisa proposta.

Fica claro que o paciente ou seu representante legal, pode a qualquer momento retirar seu CONSENTIMENTO LIVRE E ESCLARECIDO e deixar de participar desta pesquisa e ciente de que todas as informações prestadas tornaram-se confidenciais e guardadas por força de sigilo profissional (Art. $9^{\circ}$ do Código de Ética Odontológica).

Por estarem de acordo assinam o presente termo.

Bauru-SP, de de . 


\section{Anexo B - Modelo da Carta de Informação ao Paciente}

\section{CARTA DE INFORMAÇÃO AO PACIENTE}

Caro Senhor(a)

Como é de seu conhecimento, existe a necessidade de remoção dos seus terceiros molares, que são os dentes mais posteriores da arcada dentária, também conhecidos como dentes do siso e, para isso, serão realizadas 2 cirurgias.

Estamos realizando uma pesquisa que tem a finalidade de avaliar a eficácia de um material para enxerto que, com seu consentimento, será utilizado em uma das cirurgias.

Esse material é um derivado de osso bovino triturado que passa por um processo de retirada de todas as células. Desta forma, o risco de rejeição é praticamente nulo e a chance de ocorrer uma infecção é a mesma de uma cirurgia normal.

O material será utilizado para preencher a cavidade óssea resultante da retirada do dente inferior, em um dos lados. No outro lado não será colocado nenhum material, sendo uma cirurgia comum.

Durante a cirurgia e em retornos após 60 e 180 dias serão realizadas radiografias em ambos os lados para avaliação do material e do processo de cicatrização, pela comparação entre o lado em que o material foi utilizado e o lado em que não foi utilizado. Para isso, é de fundamental importância o seu retorno para os exames nas datas e horários marcados.

Também poderão ser realizadas fotografias da região com a finalidade de publicação científica e/ou atividades didáticas.

Como em qualquer cirurgia, deverão ser seguidas as orientações pós-operatórias e principalmente quanto aos medicamentos prescritos.

Junto desta carta de esclarecimento o(a) senhor(a) receberá um termo de consentimento que o incluirá na pesquisa e reafirma sua concordância em comparecer aos retornos previstos.

Caso não concorde em participar da pesquisa, não haverá interferência em seu atendimento pela Disciplina.

Desde já, agradecemos a colaboração.

C.D. Etiene de Andrade Munhoz Mestranda em Estomatologia
Prof. Dr. Osny Ferreira Júnior Orientador da Pesquisa 


\section{Anexo C - Modelo da Ficha de Dados Clínicos}

\section{FICHA DO PACIENTE - DADOS CLÍNICOS}

Paciente : Prontuário:

Idade: anos

Data de nascimento:

Dados pré operatórios:

Posição dos dentes:

Grau de Irrompimento:

Dados trans-operatórios:

LADO DIREITO:

Data:

Grupo: ( ) controle ( ) experimental

Osteotomia: ( ) sim () não

Odontossecção: ( ) sim ( ) não

LADO ESQUERDO:

Data:

Grupo: ( ) controle ( ) experimental

Osteotomia: ( ) sim ( ) não

Odontossecção: ( ) sim ( ) não

Dados pós operatórios:

\section{A 7 DIAS:}

\section{LADO DIREITO}

Dor: ( ) sim ( ) não

Infecção: ( )sim ( ) não

LADO ESQUERDO

Dor: ( ) sim ( ) não

Infecção: ( )sim ( ) não

60 DIAS

LADO DIREITO:

Data: _ / I

LADO ESQUERDO:

Data: _ I I

\section{$\underline{180 \text { DIAS }}$}

LADO DIREITO:

Data: $1 / 1$

LADO ESQUERDO:

Data: 


\begin{tabular}{|c|c|c|c|c|c|c|}
\hline Número & Paciente & Idade & Sexo & Posição dos 3os molares & Lado exp. & Lado cont. \\
\hline 1 & A.C.A. & 25 & $\mathrm{~F}$ & horizontais & esquerdo & direito \\
\hline 2 & A.B.A. & 17 & $\mathrm{~F}$ & mesioangulados & direito & esquerdo \\
\hline 3 & A.P.M. & 16 & $\mathrm{~F}$ & mesioangulados & esquerdo & direito \\
\hline 4 & C.R.F.S. & 23 & $\mathrm{~F}$ & distoangulados & esquerdo & direito \\
\hline 5 & C.S. & 23 & $\mathrm{~F}$ & vertical & direito & esquerdo \\
\hline 6 & D.C.V. & 18 & $\mathrm{~F}$ & horizontais & direito & esquerdo \\
\hline 7 & K.M. & 24 & $\mathrm{~F}$ & horizontais & direito & esquerdo \\
\hline 8 & P.F.R.A. & 15 & $\mathrm{~F}$ & verticais & direito & esquerdo \\
\hline 9 & L.P.B. & 25 & $\mathrm{M}$ & horizontal & esquerdo & direito \\
\hline 10 & K.C.S.N. & 25 & $\mathrm{~F}$ & vertical & esquerdo & direito \\
\hline 11 & L.A.P. & 23 & $\mathrm{~F}$ & mesioangulados & direito & esquerdo \\
\hline 12 & M.A.P. & 20 & $\mathrm{M}$ & mesioangulados & esquerdo & direito \\
\hline 13 & M.S.J. & 17 & $\mathrm{M}$ & mesioangulados & esquerdo & direito \\
\hline 14 & N.B.D. & 17 & $\mathrm{~F}$ & verticais & esquerdo & direito \\
\hline 15 & C.N.R. & 15 & $\mathrm{~F}$ & mesioangulados & esquerdo & direito \\
\hline 16 & D.R.G. & 18 & $\mathrm{~F}$ & mesioangulados & esquerdo & direito \\
\hline 17 & G.O.A. & 20 & $\mathrm{~F}$ & mesioangulados & direito & esquerdo \\
\hline 18 & C.R.F. & 21 & $\mathrm{~F}$ & mesioangulados & esquerdo & direito \\
\hline 19 & E.L.P. & 25 & $\mathrm{M}$ & mesioangulados & esquerdo & direito \\
\hline 20 & L.Z.B. & 24 & $\mathrm{~F}$ & mesioangulados & esquerdo & direito \\
\hline 21 & J.F.S. & 19 & $\mathrm{~F}$ & mesioangulados & esquerdo & direito \\
\hline 22 & K.B.D. & 16 & $\mathrm{~F}$ & verticais & direito & esquerdo \\
\hline 23 & T.M.A. & 17 & $\mathrm{M}$ & mesioangulados & direito & esquerdo \\
\hline 24 & M.F.M. & 21 & $\mathrm{~F}$ & verticais & esquerdo & direito \\
\hline 25 & M.D.G. & 18 & $\mathrm{~F}$ & mesioangulados & esquerdo & direito \\
\hline 26 & R.D.N. & 21 & $\mathrm{M}$ & mesioangulados & esquerdo & direito \\
\hline 27 & R.P.P. & 23 & $\mathrm{M}$ & mesioangulados & direito & esquerdo \\
\hline 28 & R.C.M. & 22 & $\mathrm{M}$ & mesioangulados & esquerdo & direito \\
\hline 29 & A.L.B. & 17 & $\mathrm{~F}$ & mesioangulados & direito & esquerdo \\
\hline 30 & B.B.P. & 17 & $\mathrm{~F}$ & mesioangulados & esquerdo & direito \\
\hline 31 & C.F.O. & 17 & $\mathrm{~F}$ & mesioangulados & esquerdo & direito \\
\hline 32 & F.S. & 17 & $\mathrm{~F}$ & mesioangulados & direito & esquerdo \\
\hline 33 & E.P.B. & 17 & $\mathrm{~F}$ & mesioangulados & direito & esquerdo \\
\hline 34 & M.L.A. & 19 & $\mathrm{~F}$ & verticais & direito & esquerdo \\
\hline 35 & J.S. & 15 & $\mathrm{~F}$ & verticais & esquerdo & direito \\
\hline 36 & K.T.O. & 18 & $\mathrm{~F}$ & mesioangulados & direito & esquerdo \\
\hline 37 & J.J.S. & 19 & $\mathrm{M}$ & mesioangulados & direito & esquerdo \\
\hline 38 & P.A.S. & 19 & $\mathrm{~F}$ & mesioangulados & direito & esquerdo \\
\hline 39 & J.M. & 20 & $\mathrm{~F}$ & mesioangulados & esquerdo & direito \\
\hline
\end{tabular}


Anexo E - Medidas da altura da crista óssea alveolar à junção amelocementária dos pacientes (E - altura experimental e C - altura controle)

\begin{tabular}{|c|c|c|c|c|c|c|c|}
\hline & C & E1 & E2 & C2M & E2M & C6M & E6M \\
\hline ACA & 6,4 & 3,8 & 3 & 6,1 & 3,8 & 2,1 & 1,7 \\
\hline ABA & 0,8 & 0,5 & 0,5 & 0,5 & 0,3 & 0,6 & 0,4 \\
\hline APM & 0,8 & 3,1 & 3,1 & 2,5 & 4,5 & 1,1 & 0,3 \\
\hline CRFS & 0,9 & 1,1 & 1,1 & 1,5 & 1,8 & 1,3 & 1 \\
\hline CS & 1,2 & 1,1 & 1,2 & 1,4 & 1,3 & 1,4 & 0,8 \\
\hline DCV & 2 & 1,7 & 1,2 & 2,1 & 2 & 1,7 & 0,5 \\
\hline KM & 1,6 & 2,9 & 2,1 & 4,3 & 1,5 & 2,2 & 1,8 \\
\hline PFRA & 2 & 1,2 & 0,9 & 0,8 & 1,1 & 0,5 & 0,6 \\
\hline LPB & 4,7 & 2,6 & 2,4 & 3,4 & 2 & 1,6 & 1,5 \\
\hline KCSN & 0,9 & 1,5 & 1,4 & 1,3 & 0,9 & 1,1 & 1,4 \\
\hline LAP & 2,9 & 2,7 & 3,8 & 1,8 & 2,5 & 1,4 & 1,7 \\
\hline MAP & 1,6 & 1,7 & 1,7 & 1,3 & 1,9 & 1 & 0,3 \\
\hline MSJ & 0,6 & 0,7 & 0,9 & 1,1 & 1,2 & 0,6 & 0,7 \\
\hline NBD & 1,1 & 1,5 & 1,3 & 0,8 & 1,2 & 1 & 0,4 \\
\hline CNR & 0,6 & 1,5 & 1,5 & 0,6 & 0,9 & 0,5 & 0,7 \\
\hline DRG & 1,9 & 2 & 2 & 0,8 & 0,9 & 0,4 & 0,7 \\
\hline GOA & 0,8 & 0,9 & 0,9 & 1,3 & 1,4 & 0,8 & 0,7 \\
\hline CRF & 1,3 & 1,4 & 1,4 & 2,4 & 1,3 & 1,3 & 0,6 \\
\hline ELP & 1,6 & 3,3 & 3,3 & 1,7 & 2,7 & 0,7 & 0,9 \\
\hline LZB & 2,2 & 3,5 & 3,2 & 1,8 & 4,4 & 2,5 & 1,7 \\
\hline JFS & 1,3 & 1,5 & 1,9 & 1,8 & 0,9 & 1,7 & 0,7 \\
\hline KBD & 1,4 & 1,4 & 1,3 & 1,4 & 1,1 & 0,7 & 0,9 \\
\hline TMA & 1,2 & 1,1 & 1,1 & 1,4 & 1,5 & 1,4 & 0,8 \\
\hline MFM & 1 & 1,2 & 0,9 & 1,7 & 1,1 & 0,9 & 1,1 \\
\hline MDG & 0,9 & 1 & 1,6 & 0,7 & 1,3 & 1,1 & 0,9 \\
\hline RDN & 2,8 & 3,2 & 2,7 & 3,3 & 2,4 & 1,5 & 1,1 \\
\hline RPP & 2,1 & 3 & 2,5 & 2,4 & 2,5 & 1,4 & 1,9 \\
\hline RCM & 5,1 & 3,2 & 3,3 & 4,2 & 3,1 & 1,9 & 1,7 \\
\hline ALB & 1 & 1,7 & 1,8 & 1,2 & 1,6 & 0,3 & 0,6 \\
\hline BBP & 1,4 & 2 & 1,9 & 1,2 & 1,2 & 1,1 & 1,2 \\
\hline CFO & 2 & 0,7 & 1,4 & 1 & 1,2 & 1,4 & 0,9 \\
\hline FS & 1,8 & 1,4 & 1,6 & 1,2 & 1,1 & 1,5 & 1 \\
\hline EPB & 1,3 & 1,4 & 1,1 & 1,2 & 0,8 & 1,2 & 0,8 \\
\hline MLA & 0,8 & 0,9 & 0,7 & 1,2 & 1 & 0,7 & 0,7 \\
\hline JS & 1,3 & 0,6 & 0,7 & 1,1 & 0,4 & 1,1 & 0,6 \\
\hline KTO & 1,5 & 1,2 & 1,2 & 0,6 & 1 & 0,9 & 0,5 \\
\hline JJS & 0,6 & 2,4 & 2,7 & 3,2 & 2,6 & 0,9 & 1,1 \\
\hline PAS & 1 & 1,4 & 1,9 & 1,2 & 1,1 & 0,6 & 0,7 \\
\hline JM & 1 & 0,7 & 1,1 & 0,9 & 1,1 & 1,2 & 1,2 \\
\hline
\end{tabular}


Anexo F - Medidas de densidade óssea médias (E - densidade experimental e C - densidade controle)

\begin{tabular}{|c|c|c|c|c|c|c|c|}
\hline & C & E1 & E2 & C2M & E2M & C6M & E6M \\
\hline ACA & 104,34 & 130,783333 & 196,22 & 94,31166667 & 157,39167 & 161,52333 & 132,725 \\
\hline ABA & 139,546667 & 46,625 & 142,4075 & 138,7883333 & 113,6775 & 152,76833 & 118,0575 \\
\hline APM & 113,826 & 84,8783333 & 184,476 & 139,375 & 164,41667 & 142,485 & 193,444 \\
\hline CRFS & 112,165 & 142,243333 & 150,028333 & 202,3383333 & 177,69333 & 77,458333 & 122,21 \\
\hline CS & 142,266667 & 161,676667 & 139,833333 & 172,51 & 112,71333 & 179,51167 & 186,725 \\
\hline DCV & 94,1933333 & 101,508333 & 155,998333 & 128,15 & 124,995 & 145,145 & 179,23167 \\
\hline $\mathbf{K M}$ & 166,595 & 91,514 & 183,388333 & 124,912 & 168,82667 & 183,88 & 201,13333 \\
\hline PFRA & 101,956667 & 92,486 & 148,034 & 136,15 & 166,60333 & 176,89 & 141,25 \\
\hline LPB & 129,785 & 109,241667 & 193,165 & 124,8916667 & 175,765 & 155,265 & 188,74667 \\
\hline KCSN & 182,3125 & 108,054 & 142 & 175,0275 & 98,196 & 164,295 & 136,486 \\
\hline LAP & 101,0725 & 159,578 & 167,511667 & 163,03 & 159,50833 & 135,63 & 142,76667 \\
\hline MAP & 7,1 & 118,82 & 172,4 & 666 & 172,09 & 87,78 & 153,804 \\
\hline MSJ & 90,67 & 141,148333 & 212,896667 & 136,1225 & 180,7175 & 139,394 & 206,7875 \\
\hline NBD & 132,068333 & 167,892 & 157,815 & 148,755 & 163,66 & 149,594 & 176,296 \\
\hline CNR & \begin{tabular}{|l}
121,885 \\
\end{tabular} & 133,018 & 142,0025 & 134,5466667 & 182,074 & 170,35667 & 161,125 \\
\hline DRG & 854 & 89,182 & 140,8375 & 135,6666667 & 176,62 & 168,95 & 160,745 \\
\hline GOA & 163,274 & 101,435 & 140,376667 & 177,496 & 124,865 & 215,73 & 148,175 \\
\hline CRF & 174,941667 & 188,051667 & 172,44 & 149,7625 & 189,508 & 159,75167 & 170,39833 \\
\hline ELP & 72,1633333 & 143,46 & 176,473333 & 163,725 & 134,41 & 129,85333 & 178,18333 \\
\hline LZB & 103,585 & 127,408333 & 147,781667 & 158,0516667 & 140,03333 & 111,09333 & 148,876 \\
\hline JFS & 88,6866667 & 144,342 & 184,118 & 193,2266667 & 172,43333 & 159,324 & 170,94 \\
\hline KBD & 142,165 & 134,348 & 228,642 & 160,0183333 & 184,998 & 158,692 & 167,6525 \\
\hline TMA & 151,494 & 164,336667 & 171,511667 & 179,2133333 & 187,858 & 155,415 & 179,19333 \\
\hline MFM & 104,745 & 163,40 & 147,43 & 146,6916667 & 151,1925 & 163,728 & 171,702 \\
\hline MDG & 138,676667 & 188,068 & 143,425 & 104,2716667 & 148,642 & 156,532 & 175,08667 \\
\hline RDN & 168,772 & 135,178333 & 175,886667 & 145,72 & 118,315 & 138,28167 & 158,04 \\
\hline RPP & 117,416 & 131,135 & 152,444 & 152,98 & 133,0375 & 168,50333 & 181,77 \\
\hline RCM & 82,1883333 & 122,976667 & 129,015 & 55,28 & 189,526 & 145,18 & 140,08333 \\
\hline ALB & 129,574 & 14 & 124,26 & 154,93 & 114,12333 & 138,93333 & 143,89667 \\
\hline BBP & 140,044 & 164,08 & \begin{tabular}{|l}
138,784 \\
\end{tabular} & 163,95 & 175,5 & 149,046 & 162,396 \\
\hline CFO & 145,64 & 138,801667 & 196,608333 & 141,0225 & 172,76667 & 107,6475 & 138,42 \\
\hline FS & 186,64 & 191,663333 & 187,0225 & 176,675 & 202,37333 & 158,38 & 206,06 \\
\hline EPB & 122,635 & 115,73 & 134,371667 & 144,65 & 163,465 & 141,83 & 171,18333 \\
\hline MLA & 169,538333 & 111,841667 & 128,166 & 160,285 & 186,262 & 152,28667 & 206,988 \\
\hline JS & 94,68 & 111,25 & 161,826667 & 135,03 & 175,326 & 152,51 & 164,018 \\
\hline KTO & 81,7066667 & 108,26 & 125,8875 & 163,98 & 144,27667 & 176,432 & 190,31 \\
\hline JJS & 116,908 & 151,424 & 175,956 & 135,584 & 150,585 & 151,66667 & 164,924 \\
\hline PAS & 119,196667 & 163,79 & 123,191667 & 190,0616667 & 161,86 & 174,756 & 180,128 \\
\hline JM & 115,305 & 148,693333 & 147,565 & 131,995 & 158,70667 & 135,075 & 174,17667 \\
\hline
\end{tabular}


Anexo G - Parecer favorável do Comitê de Ética em Pesquisa da Faculdade de Odontologia de Bauru, da Universidade de São Paulo.

\section{Universidade de São Paulo Faculdade de Odontologia de Bauru \\ Al. Dr. Octávio Pinheiro Brisolla, 9-75 - Bauru-SP - CEP 17012-901 - C.P. 73 PABX (0XX14)235-8000 - FAX (0XX14)223-4679 \\ Comitê de Ética em Pesquisa}

Processo $n^{\circ} 018 / 2003$

Bauru, 9 de abril de 2003

Senhor Professor,

Informamos que após o envio da documentação pendente, o projeto de pesquisa encaminhado a este Comitê denominado "Avaliação de Gent Tech como material de enxerto alveolar após exodontia de terceiros molares inferiores não irrompidos", de autoria de Etiene de Andrade Munhoz, que será desenvolvido sob sua orientação, foi APROVADO, nesta data

Comunicamos que após o envio do trabalho concluído, este Comitê enviará o parecer final, que será utilizado para a publicaçào do trabalho.

Atenciosamente,

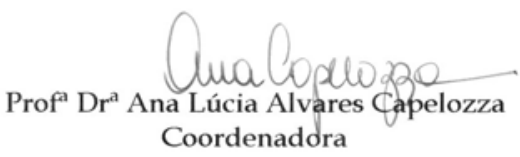

$\mathrm{Ilm}^{\circ} \mathrm{Sr}$. Prof. Dr. Osny Ferreira Junior

DD. Docente do Departamento de Estomatologia 
Referências Bibliográficas 


\section{REFERÊNCIAS BIBILIOGRÁFICAS}

1. ARCHER, W.H. Oral and maxilofacial surgery. 5ed v. 1. Philadelphia, Saunders, 1975.

2. ARTZI, Z.; TAL, H.; DAYAN, D. Porous bovine bone mineral in healing of human extraction sockets. Part 1: Histomorphometric evaluations at 9 months. J Periodontol., v.71, n.6, p.1015-23, Jun 2000.

3. ARTZI, Z.; TAL, H.; DAYAN, D. Porous bovine bone mineral in healing of human extraction sockets. Part 2: Histochemical observations at 9 months. J Periodontol., v.72, n.2, p.152-9, Feb 2001.

4. ASH JR., M.M.; COSTICH, E.R.; HAYWARD, J.R. A study of periodontal hazards of third molars. J Periodontol., v.33, n.3, p.209-19, 1962.

5. BATAINEH, A.B.; ALBASHAIREH, Z. S.; HAZZA 'A, A. M. The surgical removal of mandibular third molars: A study in decision making Quintessence Int., v.33, n.8, p.613-7, Sep 2002.

6. BISHOP, K. et al. Reproducibility of repeat bitewing radiographs determined by measurement of the distance between the amelocemental junction and the alveolar crest : an ex vivo study using human skulls. Dentomaxillofac Radiol., n.24, v.3, p.173-8, Aug 1995. 
7. BRENTEGANI, L.G.; BOMBONATO. K.F.; CARVALHO, T.L.L. Histological evaluation of the biocompatibility of a glass-ionomer cement in rat alveolus. Biomaterials, v. 18, n.2, p.137-40, Jan 1997.

8. BOER, M.P.J. et al. Complications after mandibular third molar extraction. Quintessence Int., v.26, n. 1 1, p.779-84, Nov 1995

9. CAMARGO, P.M. et al. Influence of bioactive glass on changes in alveolar process dimensions after exodontia Oral Surg Oral Med Oral Pathol., v.90, n.5, p.581-6, Nov 2000.

10. CALIXTO, et al. Implante de um floculado de resina de mamona em alvéolo dental de rato. Pesqui Odontol Bras., v.15, n.3, p.257-62, jul-set. 2001.

11. CARMAGNOLA, D.; ADRIAENS, P.; BERGLUNDH, T. Healing of human extraction sockets filled with Bio-Oss $®$. Clin Oral Impl Res., v.14, n.2, p.137-43, April 2003.

12. CARPIO, L.C. et al. Evaluation of a simple modified radiographic alignment system for routine use. J Periodontol. v.65, n. 1, p.62-7, Jan 1994.

13. CLASEN, N.F.; AUN, C.E. Radiografia digital direta: análise dos principais sistemas e recursos. Rev Odontol UNICID, v.10, n.2, p.109-120, jul-dez, 1998. 
14. DENISSEN, H. et al. Alveolar bone response to submerged bisphosphonate-complexed hidroxyapatite implants. J Periodontol., v.71, n.2, p.279-86, Feb 2000.

15. DODSON, T.B. Reconstruction of alveolar bone defects after extraction of mandibular third molars. A pilot study. Oral Surg Oral Med Oral Pathol., v.82, n.3, p.241-7, sep 1996.

16. DUINKERKE, A.S.H. et al. Evaluation of a technique for standardized periapical radiographs. Oral Surg Oral Med Oral Pathol., v.44, n.4, p.646-51, Oct 1977.

17. ESLAMI, A.; SADEGHI, E.; VAN SWOL, R.L. The prevalence of osseous defects on the distal aspects of the mandibular second molar in the absence of the third molar in a dental student population. Quintessence Int., v. 16, n.5, p.363-6, May 1985.

18. GARCIA, R.R.; BARBOSA, J.R. Histologic study of a bovine desmineralized bone matrix on bone repair process in rabbits calvaria Indian J Dent Res. v. 11, n.4, p.131-8, Oct-Dec 2000.

19. GENIUS - DIVISÃO BAUMER S.A. Gen-Tech - Enxerto ósseo composto RMS: 103.455.00001. Disponível na Internet. http://www.genius.ind.br 21. fev. 2005.

20. GIGLIO, F.P.M. Avaliação de duas formas de tratamento da raiz distal do segundo molar inferior após a exodontia do terceiro molar 
adjacente não-irrompido Bauru, 2003. 137p. Dissertação (Mestrado) - Faculdade de Odontologia de Bauru, Universidade de São Paulo.

21. GIGLIO, J.A. et al. Effect of removing impacted third molars on plaque and gingival indices. J Oral Maxillofac Surg., v.52, n.6, p.584-7, June 1994.

22. GREGORI, C. Cirurgia odontológica para o clínico geral. led São Paulo, Sarvier, 1988.

23. GRÖNDAHL, H.G.; LEKHOLM, U. Influence of mandibular third molars on related supporting tissues. Int J Oral Surg., v.2, n.4, p.137-42, 1973.

24. GÜLALDI, N.C.M. et al. Scintigraphic evaluation of healing response after heterograft usage for alveolar extraction cavity. Oral Surg Oral Med Oral Pathol., v.85, n.5, p.520-5, May 1998.

25. HAUSMANN, E. et al. Effect of x-ray beam vertical angulation on radiographic alveolar crest level measurement. J Periodont Res., v.24, n.1, p.8-19, Jan 1989.

26. HAUSMANN, E. et al. A reliable computerized method to determine the level of the radiographic alveolar crest. J Periodont Res., v.24, n.6, p.368-9, Nov 1989. 
27. HERCULANI, P.P. et al. Tratamento de defeito ósseo perene em calvária de cobaia com membrana de cortical óssea bovina liofilizada associada ou não a enxerto ósseo bovino desmineralizado Rev Bras Implant., v. 1, n. 1, p.7-14 abr/jun. 2000.

28. HIROTA, L.; REZENDE, M.L.R.; GRANJEIRO, J.M. Avaliação clínica e histológica de uma associação de biomateriais (Gen-Tech) em levantamento de seios maxilares Encontro Científico de PósGraduação HRAC-USP., v.5, p.42, 2003.

29. INDOVINA JR., A.; MICHAEL, S.B. Comparison of 3 bone substitutes in canine extraction sites. J Oral Maxillofac Surg., v.60, n. 1, p.53-8, Jan 2002.

30. JEAN, A. et al. Digital image ratio: a new radiographic method for quantifying changes in alveolar bone. Part II: Clinical application. J Periodont Res., v.31, n.8, p.533-9, Nov 1996.

31. JOLY, J. et al. Clinical and radiographic evaluation of periodontal intrabony defects treated with guided tissue regeneration. A pilot study. J Periodontol., v.73, n.4, p.353-9. Apr 2002.

32. KHOCHT, A. et al. Comparison of direct digital and conventional intraoral radiographs in detecting alveolar bone loss. JADA., v.134, n.11, p.1468-75, Nov 2003. 
33. KIRKEGAARD, E.; ZEUNER, P. A method to obtaining periodic identical bitewings radiographs. Scand J Dent Res., v.82, n.8, p.632-5, 1974.

34. KUGELBERG, C.F. Periodontal healing two and four years adter impacted lower third molar surgery. A comparative retrospective study. Int J Oral Maxillofac Surg., v. 19, n.6, p.341-5, Dec 1990.

35. KUGELBERG, C.F. et al. Periodontal healing after impacted lower third molar surgery. A retrospective study. Int J Oral Surg., v. 14, n. 1, p.29-40, Feb 1985.

36. KUGELBERG, C.F. et al. Periodontal healing after impacted lower third molar surgery. A retrospective study. Int J Oral maxillofac Surg., v. 15, n.6, p.675-86, Dec 1986.

37. KUGELBERG, C.F. et al. Periodontal healing after impacted lower third molar surgery in adolescents and adults. A prospective study. Int J Oral Maxillofac Surg., v.20, n. 1, p. 18-24, Feb 1991.

38. KULLENDORFF, B.; NILSSON, M.; ROHLIN, M. Diagnostic accuracy of direct dental radiography for the detection of periapical bone lesions. Overall comparison between conventional and direct digital radiography Oral Surg Oral Med Oral Pathol., v.82, n.3, p.344-50, sep 1996. 
39. KULLENDORFF, B.; NILSSON, M. Diagnostic accuracy of direct dental radiography for the detection of periapical bone lesions. II. Effects on diagnostic accuracy after application of image processing Oral Surg Oral Med Oral Pathol., v.82, n.5, p.585-9, Nov 1996

40. LAURIS, J.R.P; COSTA, E.T; BÓSCOLO, F.N. Radiografia odontológica digitalizada: técnicas dos principais processamentos digitais. Rev ABRO., v.2, n.1, p.1-5, jan-jun. 2001.

41. LINDSEY, W.H. Osseous tissue engeneering with gene therapy for facial bone reconstruction. Laryngoscope, v.111, n.7, p.11281136, July 2001.

42. MARMARY, Y. et al. Alveolar bone repair following extraction of impacted mandibular third molars. Oral Surg Oral Med Oral Pathol., v.61, n.4, p.324-6, Apr 1996.

43. MASTERS, D.H. Bone and bone substitutes. CDA J., v. 16, n. 1, p.56-65 Jan 1988.

44. MEISTER JR., F. et al. Periodontal assessment following surgical removal of mandibular third molars. Gen Dent., v.34, n.2, p.1203, Mar/Apr 1986

45. NAIR, P.N.R.; SCHUG, J. Observations on healing of human tooth extractions sockts implanted with bioabsorbable polylacticpolyglycolic acids (PLGA) copolymer root replicas: A clinical, 
radiografic and histologic follow-up report of 8 cases. Oral Surg Oral Med Oral Pathol., v.97, n.5, p.559-69, May 2004

46. NIH consensus development conference for removal of third molar. J Oral Surg., v.38, n.3, p.235-6, Mar 1980.

47. OKAMOTO,T. et al. Implante de Boplant em alvéolos dentais. Estudo histológico em ratos. Rev Fac Odont Araçatuba, v.3, n. 1, p. 13-21, 1974.

48. OLIVEIRA, R.C. et al Tissue response to a membrane of desmineralized bovine cortical bone implanted in the subcutaneous tissue of rats. Bras Dent J., v. 15, n. 1, p.3-8, Aug 2004.

49. OSBORNE, W.H.; SNYDER, A.J.; TEMPEL, T.R. Attachment levels and crevicular depths at the distal of mandibular second molars following removal of adjacent third molars. J Periodontol., v.53, n.2, p.93-5, Feb 1982.

50. PARODI, R.J.; ESPER, M.E. Effect of topical application of citric acid in the treatment of furcation involvement in human lower molars. J Clin Periodontol., v.11, n. 10, p.644-51, Nov 1984.

51. PELL, G.J.; GREGORY, G.T. Report on a term-year study of a tooth division technique for the removal of impacted teeth. Am J Orthod., v.28, p.660, 1942. 
52. PENG, KY et al. Mandibular second molar periodontal status after third molar extraction. J Periodontol., v.72, n. 12, p.1647-51, Dec 2001.

53. PETERSON, L.J. et al. Cirurgia oral e maxilofacial contemporânea, 2.ed, Rio de Janeiro, Guanabara Koogan, 1996.

54. PETRI, W.H III; WILSON, T.M. Clinical evaluation of antibioticsupplemented bone allograft. J Oral Maxillofac Surg., v.51, n.9, p.982-5, discussion 986, Sep 1993.

55. PLOTNICK, I.J.; BERESIN, V.E.; SIMKINS, A.B. A technique for standardized serial dental radiographs. J Periodontol., v.42, n.5, p.297-9, May 1971.

56. PUNWUTIKORN,J.; WAIKAKUL, A.; OCHAREON,P. Symptoms of unerupted mandibular third molars. Oral Surg Oral Med Oral Pathol., v.87, n.3, p.305-10, Mar 1999.

57. QUEIROZ, R.R; LINO, A.P. Estudo de métodos de diagnóstico indicativos de extrações de terceiros molares inferiores. Rev Paul Odontol., v.23, n.2, p.35-38, mar-abr. 2001.

58. RALLEY, L.; CHAPNICK, P.; BAKER, G. The impacted third molar. J Canad Dent Ass., v.43, p.364-366, 1977. 
59. ROBINSON, P.D. The impacted lower wisdom tooth: to remove or to leave alone? Dent Update, v.21, n.6, p.245-8, July-Aug 1994.

60. SANT'ANA, E.; FERREIRA JR, O.; PINZAN, C.R.M. Avaliação da freqüência da posição dos terceiros molares inferiores não irrompidos. BCl., v.7; n.27, p.42-5, jul/ago/set. 2000.

61. SHAFER, W.G.; HINE, M.K.; LEVY, B.M. Tratado de patologia bucal . 4 ed. Rio de Janeiro, Interamericana, 1985.

62. SICCA, C.M. Análise tomográfica e histomorfométrica comparativa entre enxerto ósseo autógeno e enxerto ósseo xenogênico em cirurgia de levantamento de seio maxilar em coelhos. Bauru, 2005. 61 p. Dissertação (Mestrado) - Faculdade de Odontologia de Bauru, Universidade de São Paulo.

63. SOREDEX ORION CORPORATION. Digora - installation, setup and user's guide. Helsink, 1995.

64. TABA JUNIOR, M. Monitoração da progressão da doença periodontal através de imagens radiográficas digitalizadas. Bauru, 1995. 131 p. Dissertação (Mestrado) - Faculdade de Odontologia de Bauru, Universidade de São Paulo.

65. TAGA, E.M. Biomateriais para uso em clínica médico-odontológica. BCl., v.3,n. 1, p.59-70, jul-ago. 1996. 
66. TAGA, E.M. et al. Regeneração óssea guiada de alvéolos de extração dentária: Porquê faze-la? Rev Bras Implant., v.9, n.3, p.9-12, jul-set. 2000.

67. TAGA R. et al. Reparo de defeito ósseo perene em crânio de cobaia pela aplicação de osseobond. Rev Bras Implant., v. 1, n. 1, p. 13-20, jan-fev. 1997.

68. TAGA, R. et al Avaliação histológica, radiográfica e morfométrica da reparação de defeito ósseo perene em crânio de cobaia tratado com mistura de Osseobond e Biohapatita e membrana absorvível de cortical óssea bovina. JBE., v. 1, n. 1, p.78-87 Jan 2000.

69. TAVANO,O. et al. Estudo da densidade radiográfica digital do tecido ósseo face ao implante do polímero de mamona e coelhos. Rev Fac Odont Bauru., v.7, n.3/4, p.53-8, jul-dez. 1999.

70. TETSCH, P.; WAGNER, W. Operative extraction of Wisdom Teeth. Littleton, Mass, 1985. apud VECCl et al. Complicações pósoperatorias associadas à retenção dos 3 os molares inferiores Rev Facul Odontol Porto Alegre v.4 1, n.2, p.44-50 dez. 2000.

71. THRONDSON, R.R.; SEXTON, B.S. Grafting mandibular third molar extraction sites: A comparison of bioactive glass to a nongrafted site. Oral Surg Oral Med Oral Pathol., v.94, n.4, p.413-9, Oct 2002. 
72. URIST, M.R. Bone: formation by autoinduction. Science, v.150, n. 3698, p.893-9, 1965.

73. VAN-DER-LINDER, W.; CLEATON-JONES, P.; LOWNIE, M. Diseases and lesions associated with tirad molars. Review of 1001 cases. Oral Surg Oral Med Oral Pathol., v.79, n.2, p.142-5, Feb 1995.

74. VERSTEEG, C.H. et al Effects of calibration and automatic greyscale adjustment on detectability of simulated bone lesions using storage phosphor system. Dentomaxillofac Radiol., v.27, n.4, p.240-4. July 1998.

75. WANG, H.L.; KIMBLE, K.; EBER, R. Use of bone grafts for the enhancement of a GRT-based root coverage procedure: A pilot case study. Int J Periodont Res Dent., v.22, n.2, p. 11 9-27, April 2002.

76. WENZEL, A.; GRÖNDAHL H.G. Direct digital radiography in the dental office. Int Dent J., v.45, n. 1, p.27-34, Feb 1995.

77. ZITZMANN, N.U et al. Alveolar Ridge Augmentation with Bio-Oss: A Histological Study in Humans. Int. J. Period Res Dent., v.21, n.3, p.289-95, Jan-Dec 2001

78. WINTER, G.B. Impacted third molars. St. Louis, Am Med Book Co, 1926. 
Abstract 


\section{Radiographic assessment of impacted mandibular third molar sockets filled with composite xenogenic bone graft}

The aim of this study was to evaluate the radiographic aspect of bone healing filled with a xenogenic graft material (Gent-tech ${ }^{\mathrm{TM}}$ ). Thirty-nine patients, ranging from 15 to 25 years with bilateral impacted mandibular molars were chosen based on bilateral mandibular similarities. After tooth extraction, one socket was filled with experimental materials. The opposite site was left to heal naturally and served as control. Bone density and crest healing were evaluated on digital radiographs taken immediately and 2 and 6 months after the surgery. The data obtained with Digora $^{\text {TM }}$ software were compared statistically. The results showed a significant decrease in the distance from the cemento-enamel junction to the alveolar bone crest, but no difference was found between the control and experimental groups. Bone density increased significantly, but no difference was observed between study periods. The image behavior observed by the authors was similar to that of the control group, suggesting high acceptance of the material as graft option. 